\title{
Monitoring Managers: Does it Matter? ${ }^{*+}$
}

\author{
Francesca Cornelli \\ London Business School \\ and CEPR
}

\author{
Zbigniew Kominek \\ European Bank for Reconstruction \\ and Development (EBRD)
}

\author{
Alexander Ljungqvist \\ Stern School of Business \\ New York University \\ ECGI and CEPR
}

December 20, 2010

\footnotetext{
* The views expressed in this paper are those of the authors and not necessarily of the EBRD. We are grateful to the staff of the EBRD for advice and help with the data, in particular to Erik Berglöf, Gian Piero Cigna, Simon Commander, Henry Potter, and Hans Peter Lankes as well as to members of their respective departments. Thanks for helpful discussions go to Renée Adams, Huasheng Gao, Radhu Gopalan, Simon Johnson, Fausto Panunzi, Daniel Paravisini, Antoine Renucci, Geoff Tate, and Alexander Vedrashko. We also thank Ashwini Agrawal, Giacinta Cestone, Theo Dimopoulos, William Greene, Denis Gromb, Christopher Hennessy, William Janeway, Dirk Jenter, Marco Manacorda, Holger Mueller, Philipp Schnabl, and Tarun Ramadorai as well as audiences at various seminars and conferences for helpful comments. Nelson Costa-Nato provided excellent research assistance and Katrin Robeck provided invaluable help assembling the data while interning at the EBRD. Ljungqvist thanks the Ewing Marion Kauffman Foundation for generous financial support. Part of the research was conducted while Cornelli visited the Einaudi Institute in Rome, whose hospitality is gratefully acknowledged. All errors are our own.

${ }^{\dagger}$ Address for correspondence: New York University, Stern School of Business, Suite 9-160, 44 West Fourth Street, New York NY 10012-1126. Phone 212-998-0304. Fax 212-995-4220. e-mail al75@nyu.edu.
} 


\title{
Monitoring Managers: Does it Matter?
}

\begin{abstract}
We document how gathering 'hard' and 'soft' information helps boards of directors to learn a CEO's ability over time; test under what circumstances boards fire CEOs; and show that such interventions lead to improved firm performance. Our empirical design exploits detailed hard information about performance relative to pre-agreed, firm-level targets and soft information reflecting the board's views of CEO actions, CEO decisions, and CEO competence coupled with plausibly exogenous variation due to the staggered adoption of corporate governance laws in formerly Communist countries between 1993 and 2010. We find that CEOs are fired when a firm underperforms its targets and, especially, when evidence has mounted that they are incompetent, but not when poor performance reflects factors deemed explicitly to be beyond their control or for making 'honest mistakes.' The level of CEO turnover increases following corporate governance reforms that increase board power, as does the sensitivity of CEO turnover to soft information relative to that of hard information. Following forced CEO turnover, firms see performance improvements and their investors are considerably more likely to eventually sell them at a profit.
\end{abstract}

Key words: Corporate governance, large shareholders, boards of directors, active monitoring, CEO turnover, legal reforms, transition economies, private equity.

JEL classification: G34, G24, G32, K22, O16, P21. 
Boards of directors are tasked with ensuring that firms are run by competent managers who act in their shareholders' interest. ${ }^{1}$ This involves not only the provision of appropriate incentives but also what Tirole (2001) calls active monitoring. An active monitor collects information about the firm's operations or the manager's ability and - in contrast to a passive monitor such as a financial analyst, rating agency, or the media - is in a position to fire the manager if he believes firm value is not being maximized. As monitoring benefits all investors while being privately costly to provide, directors are more likely to engage in monitoring if they have skin in the game. In practice, therefore, we expect active monitoring to be more prevalent among firms with sufficiently large shareholders (Shleifer and Vishny (1986)).

Much of the empirical literature on corporate governance and boards studies the provision of incentives and pays less attention to monitoring. In this paper, we ask if boards with large shareholders indeed engage in active monitoring and whether such monitoring in turn improves performance. Our data allow us to document what types of information boards collect and how they weight each type when taking a key decision: whether to fire the CEO. We show that boards engage in monitoring in the sense of collecting 'hard' (i.e., verifiable) and 'soft' (i.e., nonverifiable) information about the firm's operations and the CEO's ability. We also show that boards act on their information and so monitor actively in Tirole's terminology: They fire the CEO in response to negative hard information (i.e., poor performance relative to agreed targets) and when their soft information suggests that he is incompetent.

Learning about the CEO's ability requires that the board can filter out noise when evaluating the CEO. We show that monitoring enables the board to distinguish between bad luck or honest mistakes on the one hand and behavior or decisions that would raise concerns about the CEO's ability and so about the company's future performance on the other. Specifically, we find that boards in our data fire the CEO only in response to the latter concerns rather than for poor performance that was the result of bad luck or of a decision that was wrong ex post but reasonable ex ante.

Our setting allows us to observe an exogenous legal change in a board's ability to act on the information it collects - that is, we observe exogenous transitions from passive to active monitoring. Not surprisingly, we find that boards that acquire the legal power to fire CEOs without needing approval

\footnotetext{
${ }^{1}$ The literature on corporate governance and boards is surveyed in Shleifer and Vishny (1997) and Adams et al. (2008).
} 
from shareholders at large are more likely to do so. More interestingly, we also find that the sensitivity of CEO turnover to soft information doubles when boards are allowed to act on their information, while the sensitivity to hard information remains unchanged. This is an important result because it suggests that active monitors can take actions based on soft information that may be difficult to convey convincingly to shareholders who are not represented on the board. Thus, if the board lacks the power to act on what it observes, it is possible that incompetent CEOs are allowed to stay in post for too long.

Finally, we exploit the exogenous variation in a board's ability to fire the CEO to investigate if CEO turnover improves performance. While it would be surprising if it didn't, there is scant prior evidence of a causal effect due to the difficulty of finding suitable instruments. An instrument is needed because we do not observe the counterfactual, that is, what performance would have been had the CEO not been fired. Boards presumably intervene in firms expected to otherwise perform poorly, so naïvely comparing the performance of firms with and without forced CEO turnover would likely pick up unobserved differences in the quality of management or of the firm and not just the effect of CEO turnover. Solving this selection problem using a natural experiment, we show that firing incompetent CEOs leads to large improvements in performance. This last piece of evidence closes the loop: We show that boards engage in monitoring, act on the information collected, and that such actions improve performance.

Our tests are based on unique data for an 18-year panel of 473 private-sector firms in 19 transition economies in Central and Eastern Europe and Central Asia that were financed by 43 private equity funds following the collapse of the Soviet Union. This somewhat unusual setting has several advantages.

- The private equity funds have board representation and as large (usually minority) shareholders have skin in the game and thus an incentive to engage in monitoring.

- As a first approximation, we know what the board knows. Specifically, we have access to semiannual summaries of the hard and soft information boards collect and the conclusions they draw. Boards do not usually reveal their views of the firm's prospects or the CEO's ability. Our data thus allow us to overcome the perennial black-box problem in empirical corporate governance research.

- We also know what actions boards take in response to the information they collect. Specifically, we know whether a CEO was fired or left despite the board's attempts to retain him. Since boards rarely 
publicly announce the true reason a CEO departed, our data thus allow us to avoid the usual guesswork in empirical research on CEO turnover: Was he pushed or did he jump?

- The countries in our dataset emerged from Communism with no legal basis for boards to be active monitors. Initially, CEOs could only be removed by majority vote at the shareholders' meeting. Over time, aided by institutions such as the European Commission and the World Bank, many transition economies adopted Western-style laws granting boards the power to fire CEOs. We exploit these staggered reforms to test whether active monitoring improves performance causally. ${ }^{2}$ The transition-economy setting greatly improves identification. The fact that transition economies experienced such dramatic variation in the laws governing board actions enables us to exploit variation along the "extensive" board-power margin, where we are more likely to be able to detect an effect. Developed countries, by contrast, have long had governance laws and so empirical work necessarily seeks to exploit relatively minor "intensive-margin" changes to board power. The 2002 Sarbanes-Oxley Act, for example, did increase board power in the U.S. somewhat, though from an already high level.

The importance of careful identification becomes obvious when we naïvely regress performance on CEO turnover. In such a regression, performance does not improve after a CEO has been fired and even shows some evidence of decline. This reflects the selection bias discussed earlier. Once we use law changes as an instrument for CEO turnover, we find a strong and positive performance effect, both statistically and economically. To illustrate, firing the CEO nearly doubles the probability that a sample firm will be successful on one performance measure and on another helps a firm move from underperforming the board's expectations to beating its targets the following year. Not firing a CEO the board has come to view as incompetent, on the other hand, hurts subsequent performance.

Is the CEO turnover effect truly causal? Identification requires that our instrument - legal changes in board power - correlate with CEO turnover but not directly with performance nor with omitted variables that correlate with performance. The first condition is easily met. We show that boards are significantly more likely to intervene when given the legal power to fire the CEO than before. In our sample, the

\footnotetext{
${ }^{2}$ Staggered law changes are widely used as an instrument in empirical research. For an example that exploits variation in the adoption of anti-takeover legislation across U.S. states, see Bertrand and Mullainathan (2003).
} 
unconditional likelihood that a CEO is fired increases from around 3\% a year to more than $13 \%$ a year when the law changes, and the conditional likelihood (controlling for the board's information set, macroeconomic conditions, and shocks to the country's business environment) roughly doubles. While the second condition - the exclusion restriction - can never be tested directly, we provide evidence against two leading concerns: That greater board power made it more difficult for CEOs to get away with moral-hazard behavior such as shirking, so performance improved simply because CEOs worked harder after a law change. And that law changes caused investors to target firms whose performance could be improved by firing incompetent managers, leading us to overestimate the effect of CEO turnover on performance. We also show that the third condition - that law changes must not correlate with omitted variables that plausibly affect performance - is unlikely to be violated in our data.

Before summarizing our contribution, we briefly discuss to what extent our findings might generalize beyond firms with large private-equity shareholders in transition economies. We conjecture that similar patterns would emerge among private equity- or VC-backed firms in the U.S. or in other developed countries, not least because most investors in our sample came from developed countries and imported their governance practices to the transition economies in our sample. We also expect our results to generalize beyond private equity investors to large shareholders in general but perhaps with smaller effects: Unlike large shareholders in general, private equity funds might target firms that benefit especially from active monitoring, leading to larger performance sensitivities. But we do not necessarily expect that our results generalize to firms with dispersed ownership, as directors in such firms have relatively little incentive to engage in monitoring (see Kumar and Sivaramakrishnan (2008)). In fact, it is possible that the reason the literature has found little evidence of a causal link between governance and performance is precisely because it has tended to focus mainly on firms with relatively dispersed ownership (i.e., stock market-listed firms). In our view, focusing instead on firms with large shareholders maximizes the chances of finding evidence of monitoring and its effect on performance.

This paper makes contributions to several strands of research. In contrast to the existing literature on boards, we focus on the information boards collect, what they learn from it, and what actions they take in response. Our results illustrate that monitoring matters, in the sense that it helps boards learn a CEO's 
ability, rather than relying solely on easily observable but noisy output measures such as accounting performance. While many papers have analyzed the determinants of CEO turnover, we believe we are the first to have access to the soft information boards collect, which turns out to be a key determinant of CEO turnover in our data. ${ }^{3}$ The importance of soft information for board decisions has not previously been recognized in the literature. ${ }^{4} \mathrm{We}$ also ask whether CEO turnover has a causal and beneficial impact on performance and find that it does. This novel result suggests that CEO selection and dismissal are key drivers of performance.

In our data, performance improves substantially when boards are given the legal power to fire the CEO. This highlights the importance of allowing boards to act on their information (i.e., to monitor actively in Tirole's (2001) terminology) and echoes the result from the law and finance literature that shareholder-friendly laws are associated with more vigorous corporate activity (see La Porta et al. (2008)). However, while the law and finance literature has mainly made its point through cross-country comparisons, we can exploit within-country variation to identify the channel more directly.

Much of the VC literature focuses on the board's advisory function. For example, Bottazzi, Da Rin, and Hellmann (2008) show that VCs improve the performance of their portfolio firms by helping to recruit board members or arranging follow-on funding. Hellmann and Puri (2000, 2002) and Acharya, Hahn, and Kehoe (2008) provide related evidence, while Kortum and Lerner (2000) study VCs' beneficial effect on innovation. We add to this literature by focusing on the board's monitoring role.

Finally, the development economics literature has demonstrated the importance of the rule of law and institutions for a country's macroeconomic growth. We provide parallel microeconomic evidence by showing that corporate governance laws can have a strong influence on corporate performance, at least in the presence of sophisticated investors such as the private equity funds in our dataset.

\section{Sample and Data}

Our data come from the European Bank for Reconstruction and Development (EBRD). The EBRD

\footnotetext{
${ }^{3}$ Our paper is complementary to Kaplan, Klebanov, and Sørensen (2010) who ask what ex ante observable characteristics boards consider when hiring a CEO and whether these characteristics correlate with subsequent performance. In contrast, we take hiring as given and ask if monitoring enables boards to learn about CEO characteristics that were not observable ex ante. ${ }^{4}$ Instead, the literature has studied soft information in the context of financial transactions (especially lending decisions) and the scope of the firm; see Petersen (2004) for a review
} 
was established to assist formerly Communist countries in transitioning to a market economy. As a part of this mission, the EBRD has sought to help a private equity industry get off the ground. It has done so by being an anchor investor in private equity funds with a geographic focus on transition economies, managed by third-party investment managers. These funds have standard profit-maximizing objectives and raised most of their capital from private investors, such as pension funds and college endowments. Apart from their focus on transition economies, the funds are no different from those studied in the private equity and $\mathrm{VC}$ literatures, as the following fund description, taken from our sample, illustrates:

"[The fund] provides capital for private, medium-sized companies with strong prospects for growth and profitability. Specifically, the fund will target companies that have: (i) a leading or prominent position within their industry, (ii) a good management team, [and] (iii) a large and growing market for their products and services.”

We have detailed data for all 43 funds the EBRD invested in, which in turn made investments in 473 mostly private-sector firms across 19 transition economies. We estimate that the 43 funds account for around two-thirds of all private equity funds that focused on transition economies over our sample period. ${ }^{5}$ The data we use in this paper were originally gathered for a special EBRD report on its private equity program. ${ }^{6}$ The EBRD also publishes a detailed annual analysis of the program on its website. ${ }^{7}$

Sample funds were raised between 1992 and 2004 and range in size from $€ 15.3$ million to $€ 300.8$ million, with an average of $€ 93.1$ million - comparable to VC funds in the U.S. (see Hochberg, Ljungqvist, and Lu (2007)). Thirty-three funds were sponsored by experienced Western fund managers, mostly from the U.S. and U.K.; the remaining 10 were sponsored by Western-trained local managers.

Table 1 describes the sample. The earliest investment dates from 1993. The five most active countries are Poland (with 171 investments), Russia (75), Hungary (59), the Czech Republic (44), and Romania (30). The number of deals increases from 14 in 1993 to 59 in 2000 and then falls to 20 in 2005.

The average (median) fund invested in 11 (10) portfolio firms, with a maximum of 34 . We follow each investment from inception to the earlier of exit (i.e., sale or IPO), write-off, or December 2010 when our data end. Of the 473 deals, 332 (70.2\%) were exited, 99 (20.9\%) were written off, and 42

\footnotetext{
${ }^{5}$ The EBRD invested in almost all funds meeting the minimum due-diligence requirements established by Cambridge Associates, a firm of investment advisers, reducing sample selection concerns. For an overview of these, see Dinneen (2004). ${ }^{6} \mathrm{See}$ http://www.ebrd.com/downloads/research/transition/TR06.pdf for the special report.

${ }^{7}$ See http://www.ebrd.com/downloads/FI/perf.08.pdf and http:/www.ebrd.com/pages/sector/financial/funds.shtml for the most recent data and statistics.
} 
$(8.9 \%)$ remain in a fund's portfolio as of 2010. The average firm spends 5.6 years in a sample fund's portfolio before being exited or written off. This is comparable to holding periods in U.S. VC funds (see Gompers (1995)). The range is from 1 to 14 years, and the $25^{\text {th }}, 50^{\text {th }}$, and $75^{\text {th }}$ percentile are 4,5 , and 7 years, respectively. In total, our unbalanced panel spans 2,662 firm-years.

We compute IRRs from precisely dated cash flows to and from portfolio firms, including the fund's initial (and subsequent) investment, dividends, and the proceeds (if any) from the firm's IPO, sale, or liquidation. IRRs average $6.4 \%$ and $14.8 \%$ on an equal-weighted and value-weighted basis, respectively.

Sample investments come from a wide range of industries. The EBRD classifies firms into 11 industries: Telecoms and media (90 firms), manufacturing (71), high-tech, electronics, and internet (69), services, hotels, and restaurants (57), retail (51), food \& beverages (49), construction (27), oil, gas, and mining (20), financial services (18), pharmaceuticals and medical (16), and energy (5).

Portfolio-firm information is confidential and would not normally be available to researchers. Luckily, the EBRD 'audits' each portfolio firm twice a year. Audits are carried out by EBRD staff who record detailed soft and hard information about each firm's performance, board decisions, problems, material events, etc. in standardized confidential 'monitoring reports' to which we have been given unrestricted access. The underlying information comes from the fund managers' quarterly reports; interviews with the fund managers, other investors, and portfolio-firm CEOs; the funds' confidential notes taken at board meetings; audited and internal financial statements; and site visits by EBRD staff.

Based on extensive conversations with decision-makers at the EBRD, we are confident that the monitoring reports can be viewed as an unbiased source of information. First, they are written by EBRD staff and not by the fund managers themselves, who might have an interest in distorting information. There is thus no reason for the reports to be deliberately biased. In fact, it is highly unlikely that a fund manager would deliberately withhold or distort information. Doing so would be a contractual breach of the reporting agreement between the EBRD and the fund. If detected, such behavior would significantly decrease the chances of the fund manager ever receiving new funding from the EBRD and as a result would weaken the fund manager's ability to market himself to other investors in future. Second, the monitoring reports are intended exclusively for an internal audience at the EBRD, so there is no reason 
for the reports to be anything other than candid. Third, they follow a standardized process so that each portfolio firm is audited to the same level of detail regardless of the characteristics of the investment. It is thus not the case that audits gather systematically more information in certain situations, for example around board room disputes or after legal changes in board power.

Funds typically buy minority stakes. Their average (median) equity stake is $33.7 \%(26 \%)$, and 372 of the 473 deals (78.6\%) are minority investments. Data on CEO ownership or their incentive contracts are not systematically available, nor do we have data on board composition or the number of board seats a fund manager controls (though material changes in these variables are routinely noted in the monitoring reports). Thus, in contrast to extant work on boards, we do not know what the board looks like. Uniquely, however, we have good data on what the board knows and what actions it takes. ${ }^{8}$

\section{An Empirical Model of Active Monitoring}

Our empirical analysis proceeds in three steps. First, we model the evolution of the board's views about the CEO's competence to see what kinds of signals, events, and managerial decisions lead to beliefs being updated. Next, we estimate the conditions under which the board fires the CEO. For this, we relate firing in year $t$ to the hard and soft information the board has collected as of $t-1$ (denoted $\left.I_{t-1}\right)$, controlling for law changes empowering boards to fire CEOs, $\Delta L$, and other exogenous variables, $x$ :

$$
\text { intervention }_{t}=\gamma_{1}^{\prime} I_{t-1}+\omega^{\prime} \Delta L_{t-1}+\delta_{1}^{\prime} x_{1, t-1}+\lambda_{k}+\lambda_{t}+\lambda_{j}+u_{1, t}
$$

The lambdas capture fixed effects for country $k$, year $t$, and industry $j$. Since we have a panel, we can also estimate equation (1) with portfolio-firm effects. These help control possible omitted-variable biases due to unobserved firm heterogeneity, caused for example by our lack of data on the CEO's ownership, his compensation, or the board's quality or composition. To the extent that such omitted variables are constant over time (e.g., the CEO owns a majority of the equity in every panel year), they can be removed using firm effects. As we will see, their inclusion makes little difference in practice.

Finally, we estimate the effect of forced CEO turnover on the firm's subsequent performance:

$$
\text { performance }_{t}=\beta_{2} \text { intervention }_{t}+\gamma_{2}^{\prime} I_{t-1}+\delta_{2}^{\prime} x_{2, t-1}+\lambda_{k}+\lambda_{t}+\lambda_{j}+u_{2, t}
$$

\footnotetext{
${ }^{8}$ Modeling the determinants of funds' ownership choices or the causal effects of ownership on performance is beyond the scope of the paper. Ownership is presumably chosen endogenously so to identify its causal effects requires another instrument.
} 
Equation (2) poses a tricky identification challenge. Presumably, the intervention treatment is not administered randomly but reflects the board's information set and beliefs. Boards likely intervene when firms are badly managed (in ways that are not necessarily observed by the econometrician) or are expected to otherwise perform poorly, and such firms might well underperform better-managed (i.e., untreated) firms in future, even if they subsequently perform better than they would have done absent the treatment. Unless we have perfect controls for CEO quality and expected performance, the disturbances of equations (1) and (2) will be negatively correlated, so naïvely regressing performance on intervention will yield a downward-biased estimate of $\beta_{2}$. Identification of $\beta_{2}$ thus requires an instrument. ${ }^{9}$

\subsection{Instrument}

Our instrument exploits plausibly exogenous variation in the timing of the introduction of laws empowering boards to fire CEOs. The identifying assumption is that changes in board power affect CEO turnover but do not directly affect performance. (We investigate the validity of the instrument in Section 4.2 and the plausibility of the exclusion restriction in Section 5.6.) The notions that the CEO serves at the pleasure of the board and that the board's role is to monitor the CEO do not exist in Soviet-era laws, so the reforms are dramatic. In Azerbaijan, for example, the World Bank (2005) noted that:

"There are no detailed guidelines for the roles, responsibilities, operation, qualifications or structure of supervisory boards. In practice, boards tend to be dominated by the controlling shareholder, have not assumed an independent oversight function, and are considered to play a relatively minor role in providing strategic guidance for corporations. Regular supervisory board meetings are not held in most companies."

Table 2 lists the relevant governance laws and the source texts we consulted. All but one of the 19 sample countries (Azerbaijan) enacted governance laws. These come in two forms. Our instrument is based solely on laws that granted boards statutory power to dismiss the CEO without a shareholder vote. Such laws were enacted in 13 countries accounting for 351 of the 473 sample firms. The remaining five countries adopted a weaker type of reform, permitting the shareholders' meeting to delegate its power to dismiss the CEO to the board through an amendment to the corporate charter. Amendments require at least a majority vote. In these cases, it is impossible for board power to change without a shareholder

\footnotetext{
${ }^{9}$ Data constraints rule out weaker identification strategies, such as propensity-score matching. While we have unique and detailed data on sample firms, we lack even rudimentary data on firms outside our sample. The one available database tracking unlisted European firms, Amadeus, suffers from a severe form of survivorship bias because the historical data of dead firms are eliminated from the database. See Popov and Roosenboom (2009) for further details.
} 
vote, and according to the EBRD's monitoring reports, no such votes took place in our sample firms.

We can use this fact to help validate our instrument. In Section 4.2, we will show that the enactment of laws requiring charter amendments has no effect on forced CEO turnover in our data, as expected.

When we follow a given firm over time, we expect the likelihood of forced CEO turnover to jump once the country it is incorporated in strengthens the board's powers. Figure 1 suggests that it does. It shows the annual rate of CEO turnover relative to the year boards in the country in question gained the statutory power to dismiss CEOs. In the five years prior to reform, CEO turnover is low: CEOs are fired on average in only $3.2 \%$ of firm-years. In the year the governance law comes into force, CEO turnover jumps to $13.3 \%$ and then stays on average at $9 \%$ a year for the next several years.

\subsection{Further Testable Implications}

Before reform, the power to fire a CEO rests with the shareholders' meeting. The instrument thus captures reforms that redistribute power from the shareholders' meeting to the board. The following examples, taken from the EBRD's monitoring reports of two different Polish companies, illustrate:

Pre-law change: “The fund manager's efforts to [dismiss management] were unsuccessful so far, as other shareholders rejected the fund's motion in this respect put forward at the shareholders' meeting."

Post-law change: "[The fund manager] continues to be disappointed with ... management, but has been unable to convince a sufficient number of the directors of the company to replace them. [The fund manager] has made its displeasure of managerial and financial issues known to the company... [and] has put the entire board ... on notice as to certain issues that [the fund manager] believe[s] would give cause for the board to remove the CEO."

A testable implication of power shifting to the board is that the importance of soft information in CEO firing decisions might increase following reform, compared to that of hard information. This will be the case if soft information, which is nonverifiable by definition, is more difficult to communicate persuasively to shareholders at large than to fellow board members - who after all have first-hand experience of dealing with the CEO. Hard, verifiable information, on the other hand, could be equally effective with either audience. We thus expect CEO turnover to become more sensitive to soft information, relative to hard information, following governance reform. This will, of course, be true only to the extent that shareholders and board directors do not overlap perfectly.

Furthermore, soft information should become more important after a law change only if the fund is a minority shareholder. A majority shareholder can fire a CEO at will, so changes in the board's statutory 
powers should not affect whether a CEO is fired in response to negative soft information.

\section{Variable Definitions and Descriptive Statistics}

\subsection{CEO Turnover}

Over the sample period, the 473 firms employed 665 CEOs; 181 were fired and 11 left voluntarily.

We can identify forced CEO turnover unambiguously because the monitoring reports are quite clear:

Forced: "At the year end the board of the company decided to change the CEO."

Voluntary: "The general manager of four years, who was deemed highly capable ..., has left."

It is also clear from the monitoring reports that boards typically begin to complain of management problems some time before firing the CEO - rather than after the fact. For example:

"It has been agreed that [the CEO] would have to leave in the near future. [He] has disappointed with his lack of leadership ... and overall lack of discipline and political skill."

"The relationship with the company's Managing Director ... remains difficult. [He] is unable to adjust to the [company's] needs and opportunities... Going forward, [he] would need to be replaced as a General Manager.”

Only 42 of the 181 CEO dismissals (23.2\%) occurred prior to governance reform (see Table 2). The average (median) CEO dismissal takes place 3.4 (3) years after a fund first invested in a firm. Most firms (328) see no forced CEO turnover. Those that do typically fire their CEO once (118 firms), though some go through two (18 firms) or three CEOs (nine firms).

The monitoring reports also record 170 dismissals of managers below the rank of CEO and 205 cases of boards authorizing the hiring of additional managers (so called 'management strengthening').

\subsection{Hard Information: Board Performance Expectations}

Empirical researchers either do not benchmark performance at all or they benchmark it against, say, industry averages. Our data allow us to benchmark performance against a good proxy for the board's expectations. Each fiscal year, the board and the CEO agree a formal budget for the year ahead which contains sales and profit targets as well as strategic and investment plans. At the end of the fiscal year, the EBRD monitoring reports record how the firm has performed relative to budget. Both budgeted and actual performance are 'hard' information, verifiable by outside parties such as shareholders or a court.

EBRD reviewers have access to both budgets and audited accounts when preparing their monitoring reports, but they explicitly mention both sets of numbers in only a quarter of firm-years. Fortunately, in 
almost all firm-years, the monitoring reports contain enough detail to score performance relative to budget on a five-point scale, where 3 denotes performance in line with expectations ("making budget"); 4 and 5 denote performance above and greatly above budget; and 2 and 1 denote underperformance and severe underperformance relative to budget. Here is an example of performance scored as a 2:

“Sales were 9\% below budget; EBITDA was negative as opposed to US\$2.8m budgeted profit."

Of the 2,662 firm-years in the sample, $9.5 \%$ score a $1,33.6 \%$ a $2,31.4 \%$ a $3,20.4 \%$ a 4 , and $5.1 \%$

score a 5 . The average is 2.8 . This fairly normal distribution suggests that boards have relatively realistic, achievable expectations which in turn form a suitable benchmark against which to judge performance. The following quote illustrates that boards do indeed aim for realistic budgets:

“The budgeted numbers prepared by management for ... 2004 are sales of \$242 million and EBITDA of \$32 million. [H] owever, the ... budget was challenged by the board ... and not approved due to concerns [about] how achievable these targets are. Currently management is reworking the operational budget for 2004.”

It would be nice to also control for industry performance, as other studies have done, but these data are not available on a systematic basis for our sample countries. The closest is the UN's Industrial Statistics Database 2010, which collates performance data for four-digit SIC manufacturing industries in 16 of our 19 sample countries through either 2006 or 2007 (depending on the country). Unfortunately, only 71 of our sample firms are manufacturers and there is no corresponding data for other sectors.

\subsection{Soft Information}

The EBRD monitoring reports contain a wealth of other textual information. Of particular interest are fund managers' and other directors' confidential comments regarding the CEO's ability and their views of what, if anything, may have caused a firm to underperform. Unlike accounting data, these comments are potentially difficult to verify (say, in the annual shareholders' meeting or in court) and so constitute soft information. We use three time-varying indicators to capture different types of soft information. The first equals one if in a given year directors view the $\mathrm{CEO}$ as incompetent or think that his skills are a poor match for the firm's needs, and zero otherwise. Representative examples include:

Incompetence 1: "It is now evident that the CEO lacks sufficient skills in some areas and we are searching for a suitable candidate to complement the current CEO in the senior management team."

Incompetence 2: "Given the more competitive environment on the Polish post-[EU] Accession market, the Fund Manager sees the need for a more efficient sales and marketing strategy. The CEO is being replaced with someone more competent in these areas effective January 1, 2006." 
Competence: "The top management team is strong."

On average, CEOs are viewed as incompetent or a poor match in $6.5 \%$ of firm-years. In total, boards complain about the competence of 132 of the 665 CEOs in the sample (19.8\%). Of these, $84(63.6 \%)$ are eventually fired and $16(12.1 \%)$ lead their firms into bankruptcy. The remaining 32 are not fired within our sample period, either because the board lacked the statutory power to do so (18 cases), because the board remedied the situation by strengthening the management team ( 8 cases; see the first example above) or because the fund manager couldn't muster the necessary number of director votes (6 cases).

Does this proxy capture true ability or do directors express concerns to the EBRD "strategically", to justify why they fired a CEO? Ex post justifications would be pointless before boards could legally fire CEOs. Figure 2 graphs the annual rate of directors rating a $\mathrm{CEO}$ as incompetent relative to the reform year. Boards complain just as frequently before a law change as after ( $7 \%$ of the time), suggesting that directors express their views of CEO competence whether or not they have the statutory power to act on them. This suggests the proxy captures true ability. It also suggests that by the time the law has changed, there is pent-up pressure to fire CEOs, consistent with the jump in CEO turnover we saw in Figure 1.

Our second soft-information indicator captures cases in which directors are critical of a CEO's specific actions or decisions which, in their view, caused the firm to underperform. These complaints span the spectrum from what might be called honest mistakes to traditional moral-hazard behavior. Honest mistakes are by far the most common complaint. The following two examples illustrate:

"Management made a serious mistake and signed FX options to hedge against the strengthening PLN [Polish zloty] shortly before the currency substantially weakened."

“[This food manufacturer] will end 2003 below both last year's exceptionally good performance and this year's budget. [It] allocated insufficient funds for marketing and sales support, focusing instead on better management of the existing freezer network through a team of temporary merchandisers. This proved a flawed strategy."

Even with the most expansive interpretation of what constitutes moral hazard, complaints about moral hazard are quite rare relative to the sample size of 2,662 firm-years. Exercising some judgment, we group such complaints into the following four categories familiar from the moral-hazard literature:

Shirking (7 firms): "The CEO has not been properly managing the business."

Enjoying the quiet life (12 firms): "Management was unable to control wages and salaries which were $8 \%$ higher than in the first half of 98, despite the fact that the employment was reduced by approx. 20\% in 4Qtr 98."

Self-dealing (7 firms): “... management was discovered to produce false invoices to inflate the 1997 results.” 
Empire-building (1 firm): "The company made four acquisitions in 1998 with one additional acquisition in 1Q99. The fund admits it gave [the CEO] excessive free-hand in the acquisitions."

The small number of complaints about moral hazard suggests that CEO compensation contracts and board monitoring are, on the whole, effective at controlling moral hazard problems. Given our private equity setting, this is in fact not surprising. In private equity, management's and investors' interests are relatively well aligned: Everyone gets rich only if the investment can be successfully sold.

Our final soft-information indicator captures 339 cases in which, in the board's opinion, poor performance was caused by factors beyond management's control ('bad luck'). For example:

"On 10 September the finished goods warehouse ... caught fire. The fire completely destroyed the company's warehouses as well as the main [production] facility.”

\subsection{Deal Characteristics}

Converted at historical exchange rates, average and median investment sizes are $€ 6.1$ million and $€ 4.1$ million, respectively, comparable to VC investments in the U.S. The largest deal is $€ 43.4$ million. The average and median 'post-money' valuations (i.e., deal size divided by equity stake) are $€ 65.7$ million and $€ 15.7$ million, respectively. Most investments finance expansion at private-sector firms (255 out of 473) or go into start-ups (124 deals). Privatizations are rare in our sample, accounting for only 40 of the 473 portfolio firms. Our sample is thus quite different from the types of firms studied in the transition-economics literature (see Djankov and Murrell (2002) and references therein).

Riskier firms may require more intervention and may systematically perform differently. Traditional risk proxies (say, volatility of stock returns or earnings) are unavailable as most sample firms are unlisted and accounting data is patchy. Instead, we (crudely) proxy for risk by coding whether the fund 'staged' the deal, i.e., whether the fund intended ex ante to make continued funding dependent on subsequent performance, as opposed to providing the entire funding upfront. Gompers (1995) argues that VCs stage investments to maintain the option to discontinue funding if performance disappoints. This option is more valuable, the riskier the firm. Of the 473 investments, 125 were staged. ${ }^{10}$

\subsection{Macroeconomic Conditions and Business Environment}

To remove confounding influences that are contemporaneous with our instrument (governance

\footnotetext{
${ }^{10}$ Staging does not simply capture whether an investment is in a start-up. $38.4 \%$ of staged investments are in start-ups, and $38.7 \%$ of investments in start-ups are staged.
} 
reform), we control for macroeconomic conditions using real GDP growth and for changes in a country's business environment using the EBRD transition indicator. The latter measures progress towards a market economy and is published annually. ${ }^{11}$ It is a composite of nine indices measuring reform progress in areas such as restructuring, securities markets, banking reform, and competition policy. It varies from 1 (centrally planned economy) to 4.33 (fully functioning market economy).

\section{Evolution of Board Beliefs and Determinants of CEO Turnover}

We first model the evolution of a board's view of the CEO's ability as evidence of monitoring. We then model the determinants of CEO turnover. This will show that boards monitor actively, in the sense that they act on the information they collect. Our models relate CEO turnover in year $t$ to the board's information set as of $t-1$, consisting of hard information (i.e., performance relative to budget) and soft information (i.e., the board's view of CEO competence, CEO decisions, and bad luck). We control for deal characteristics (i.e., size and risk), lagged GDP growth (to capture macroeconomic conditions), the EBRD transition indicator (to capture country-level changes in the business environment), and country, industry, and year effects. To capture the transition to active monitoring, we include an indicator which equals one if, at the start of year $t$, the board has the statutory power to fire the CEO, and zero otherwise. (We will explore other timing conventions later.) The dependent variable is binary, so we estimate probits; linear probability models are reported in the Internet Appendix. We track each deal in an annual panel from inception to the earlier of exit, write-off, or 2010. As a result, the disturbances may be correlated within firm, so we cluster the standard errors at the firm level. The Internet Appendix reports alternative results clustered at the country level (to capture possible serial correlation within countries). We also validate the key significance levels using bootstrapped Placebo regressions.

\subsection{Results}

Table 3, column 1 asks what prompts a board to complain about CEO incompetence and shows evidence consistent with learning. Boards update their beliefs based on hard information in the form of prior-year performance relative to plan, but not in response to specific managerial decisions that amount to honest mistakes, and they discount bad luck. This fits Tirole's (2006) view that boards use past

\footnotetext{
${ }^{11}$ The data are available at www.ebrd.com/pages/research/analysis/forecasts.shtml (sei.xls and sci.xls), accessed 10/2010.
} 
information in a forward-looking way, ignoring signals that are uninformative about the CEO's likely future performance. Importantly, complaints about incompetence are persistent: A board is four times more likely to complain about the CEO's incompetence if it complained about it in the previous year $(p=0.001)$. Given the relatively low pseudo- $R^{2}$ of $13.6 \%$, boards clearly update partly based on information that we as econometricians do not observe, such as their interactions with the CEO. ${ }^{12}$

Columns 2 to 7 report CEO turnover models. Incompetence is the strongest determinant of firing. The point estimate in column 2 suggests that CEOs viewed as incompetent last year are 30.3 percentage points more likely to be fired this year - a $446 \%$ increase from the unconditional probability of $6.8 \% .{ }^{13}$ The $t$-statistic is 10.24 clustered by firm and 9.06 clustered by country. This provides novel evidence that boards monitor actively: They not only gather soft information, they also act on it. Moreover, they seem to do so in a considered way: The next two coefficients in column 2 are effectively zero and suggest that boards do not fire a CEO if they attribute the previous year's poor performance to bad luck or to honest mistakes. Instead, as column 9 shows, they strengthen the management team. The absence of sanctions for making mistakes suggests that boards, on average, avoid punishing CEOs ex post for decisions that were reasonable ex ante. ${ }^{14}$ Virtually identical results obtain when we include portfoliofirm effects, which are in fact not statistically significant ( $p=0.196$; see column 3 ).

Boards also act on hard information, though the effect of our specific variable - performance relative to budget - is smaller economically than that of our measure of soft information: A unit drop in lagged performance (say, from making budget to missing budget) increases CEO turnover by 8.3 percentage points, or $122 \%(t=-6.37)$. Further lags (not shown) are insignificant, suggesting that boards take disciplinary action quickly. That CEO turnover is sensitive to hard information is not new ${ }^{15}$ though

\footnotetext{
${ }^{12}$ We find no significant change in complaints about CEO competence after governance reform. This mirrors the nonparametric results of Figure 2 and again suggests that such complaints are not reported to the EBRD strategically.

${ }^{13}$ Lagging the board's information set ensures that we are not simply capturing cases of a board reporting negative opinions to the EBRD to justify actions it has already taken.

${ }^{14}$ Jenter and Kanaan (2008) and Kaplan and Minton (2006) document that CEOs at large, publicly traded U.S. firms with dispersed shareholders are punished for negative industry shocks. While no systematic data on industry shocks exists for our sample countries, our results show that CEOs in our sample are not fired for bad performance caused by events beyond their control. Neither do we find that CEO turnover increases after country-level macroeconomic shocks.

${ }^{15}$ For related findings, see Coughlan and Schmidt (1985), Warner, Watts, and Wruck (1988), Weisbach (1988), Kim (1996), and Fee and Hadlock (2004) who relate CEO turnover to prior-year stock price performance, and Denis and Denis (1995) and Huson, Malatesta, and Parrino (2004) who relate CEO turnover to prior-year operating performance.
} 
ours is the first set of results based on a firm-level measure of performance targets.

To see if soft and hard information capture distinct signals, column 4 asks whether CEO turnover is sensitive to soft information about CEO competence even among firms that evidently perform well according to the hard information. For this purpose, we partition the sample by prior-year performance. We find that the incompetence indicator predicts CEO dismissal even among firms that make or beat budget $(p<0.001)$. Thus, soft and hard information appear to capture distinct signals.

Column 5 controls separately for the small number of cases where boards complain about moral hazard (shirking, enjoying the quiet life, self-dealing, or empire-building). We find that such complaints are not followed by more CEO turnover: The likelihood of CEO dismissal increases by only 0.6 of a percentage point with a $p$-value of $0.866 .{ }^{16}$ This is not unexpected. Shleifer and Vishny (1986) argue that the presence of large shareholders mitigates moral hazard problems, and all our sample firms have at least one large shareholder. Moreover, private equity funds tend to give CEOs strong incentive contracts, further reducing moral hazard problems.

Governance reform empowers boards to act on their information and so become active monitors. The data confirm this. Law changes have a significantly positive effect on CEO turnover, mirroring the non-parametric result in Figure 1 that CEOs are more likely to be fired after boards acquire the statutory power to dismiss them than before. The effect is large economically. Holding the other covariates in column 2 constant, for example, CEOs are 105\% more likely to be fired following governance reform.

It may be harder to convince shareholders at large to act on soft information than fellow board directors, who, after all, have seen the CEO in action. If so, we expect the sensitivity of CEO turnover to soft information to increase following governance reforms that shift the power to fire the CEO from shareholders to the board. Column 6 tests this prediction by interacting incompetence and performance relative to budget with the reform indicator. Interactions in probit models require careful interpretation. As Ai and Norton (2003) show, the economic magnitude of an interaction term in a probit does not equal the coefficient on the interaction term (or the usual marginal effect); the signs may be different;

\footnotetext{
${ }^{16}$ Not even CEOs suspected of self-dealing are necessarily fired. Of the seven such CEOs, two were fired, one bankrupted his firm, three were majority shareholders and so could not be fired, and one was eventually cleared of wrong-doing.
} 
and the statistical significance does not equal a $t$-statistic on the interaction term. Correct interpretation of an interaction term in probit instead requires computing the cross-partial derivative of the expected value of the dependent variable with respect to the interaction term, which is usually a nonlinear combination of all regressors and coefficients. Doing this, we find that the sensitivity of CEO turnover to soft information doubles after a law change, increasing by 20.3 percentage points $(p=0.017)$ from $19.8 \%$ before $(p<0.001)$. The sensitivity of CEO turnover to hard information, on the other hand, remains unchanged, changing by only -0.2 of a percentage point $(p=0.55)$. Thus, governance reform appears to make it easier for boards to act on soft information, as expected.

Column 7 tests the follow-on prediction that soft information becomes more important after reform only if the fund is a minority shareholder. This triple-difference estimate requires a full set of interaction terms involving incompetence, law changes, and ownership (and again careful interpretation, derived in Cornelissen and Sonderhof (2009)). As in column 6, we find that the sensitivity of CEO turnover to soft information nearly doubles following reform $(p=0.01)$. Prior to reform, funds with majority ownership are significantly more likely than are minority owners to fire a CEO they deem incompetent $(p=0.048)$. After reform, majority owners are as likely to act on soft information as are minority owners (summing the relevant marginal effects, the $p$-value is 0.912 ). Thus, governance reforms appear to increase the importance of soft information in CEO firing decisions only if the fund is a minority shareholder.

\subsection{Instrument Validity and Strength}

Nothing we have shown thus far requires law changes to be a valid instrument in the econometric sense. Thus, our conclusions regarding the evolution of boards' beliefs about CEO ability and the role played by soft information in CEO turnover do not depend on whether the reader views law changes as a plausible natural experiment in our setting. The remainder of the paper asks whether CEO turnover leads to performance improvements, and it is there that we will employ law changes as an instrument. Before we do so, we explore the economic validity and plausibility of this instrument from six different angles.

First, we note that in Table 3, law changes increase only CEO turnover and not the likelihood that a junior manager is fired (column 8) or that the board takes 'friendly' actions such as expanding the management team (column 9). These patterns are consistent with our identifying assumption. They 
confirm that law changes make it easier for a board to remove an unsuitable CEO but that they are not necessary to remove a junior manager. This makes economic sense since only the board (or shareholders) can fire a CEO while junior managers can be fired by senior managers (say, the CEO) regardless of the board's statutory powers. Similarly, there is no a priori reason to believe that friendly actions should become more frequent after governance reform, and indeed they do not. ${ }^{17}$

Second, recall from Section 2.1 that governance reforms that require a corporate charter amendment before boards acquire the power to fire the CEO should have no effect on CEO turnover, for the simple reason that no sample firm amended its charter in our sample period. Table 2 lists the five countries adopting this weaker governance reform. Column 1 of Table 4 confirms that this type of reform, in contrast to our instrument, only increases CEO turnover by an insignificant two percentage points.

Third, if the instrument behaves as hypothesized, it should have a characteristic time profile: Forced CEO turnover should only jump in the year the board's statutory power actually increases, not before, and then remain higher. In other words, if law changes provide an exogenous source of variation in CEO turnover, as our identification strategy requires, future law changes should not be driving current interventions. Figure 1, discussed earlier, supports this claim non-parametrically. Column 2 of Table 4 tests it formally by estimating the sensitivity of CEO turnover in year $t$ to reform that took place two or more years earlier; one year earlier; the same year; one year later; or two years later. (The omitted category is reform that took place more than two years later.) All else equal, we find no significant increase in CEO turnover in the years leading up to reform, either economically or statistically. The year boards actually acquire the power to fire the $\mathrm{CEO}$, on the other hand, turnover increases significantly, by $207 \%$. In the following years, it remains significantly higher. These results too support our identification strategy.

A fourth way to examine the plausibility of the instrument is to test whether it is the expectation of governance reform or, as our argument implies, its actual enactment that affects a board's propensity to fire a CEO. To do so, we search local newspapers in each country for the first mention of reform. In Russia, for example, the local press reported on March 16, 2000, that parliament was preparing a reform to the 1996 Federal Law on Joint Stock Companies with a view to empowering boards to fire the CEO.

\footnotetext{
${ }^{17}$ Linear probability models of all tests discussed in this section are in the Internet Appendix. They yield similar results.
} 
This reform was passed in 2001 and came into force on January 1, 2002. Our test asks whether CEO turnover increased in 2000, when reform was first mooted, or in 2002, when it became law. The results are shown in column 3 of Table 4 . We continue to find a significant increase in CEO turnover when reform comes into force $(p=0.001)$, but we find no effect - statistically or economically - when reform is first mooted ( $p=0.392)$. This too supports our identification strategy.

Governance reforms cannot affect firms that enter our sample post-reform. Thus, identification of the CEO turnover-performance relation in the next section comes solely from firms that experience a law change after entering the sample. Why then have we included all firms in the CEO turnover models shown in Table 3? Because the results shown in Table 3 are identified whether or not law changes are a plausible instrument: They focus simply on the determinants of CEO turnover. But even when Table 3 becomes the "first stage" of our performance model, in the next section, we will continue to include all firms in the estimation. This is commonly done in these situations (see for example Levitt (1996, p. 327)). While including post-reform investments obviously doesn't contribute to the identification of the CEO turnover-performance relation, doing so increases the sample size and thereby sharpens the standard errors of the remaining control variables, as we will show next.

Column 4 of Table 4 restricts the sample to investments made two or more years before reform, leaving 1,480 firm-years. The new point estimate of the effect of law changes on CEO turnover is 0.667 $(p<0.001)$, which is statistically no different from the full-sample point estimate of $0.644(p<0.001)$ reported in column 2 of Table 3 . The corresponding marginal effect of 0.068 is nearly identical to the full-sample estimate of 0.071 . Thus, the law change variable has the same effect on CEO turnover when we exclude firms that are not affected by it as it does in the full sample. We also see little change in the point estimates of the other key variables of interest - i.e., the sensitivity to the board's hard and soft information - though, as expected, some of the controls are more noisily estimated in the restricted sample. From here on, we follow Levitt (1996) and others and retain all firms. As the results in Table 4 and upcoming robustness tests show, nothing other than the efficiency with which the effects of some control variables are estimated depends on using the full sample rather than the restricted sample.

Finally, we note that law changes appear to be a strong instrument in the econometric sense. This is 
important for a weak instrument can lead to worse biases than having no instrument at all, but that is not the case in our setting: Whether we cluster the standard errors on firm or (in the Internet Appendix) on country, we find that law changes have strong statistical significance in Tables 3 and 4, and the StaigerStock (1997) tests reported in the tables formally reject the hypothesis that the instrument is weak. ${ }^{18}$

\section{Effect of Board Intervention on Investment Success and Performance}

Section 4 shows that boards update their views of a CEO's ability over time, based on hard and soft information, and that they fire him once they have concluded that he is not up to the job. In this section, we ask if such board interventions improve performance and so whether active monitoring is desirable.

Most sample firms are privately-held. Absent share prices, we measure performance either relative to budget or using the exit information shown in Table 1. Exits are a popular performance measure in the literature on privately-held firms (Gompers and Lerner (1998, 2000), Hochberg, Ljungqvist, and Lu (2007), Sørensen (2007)). We code exits using an indicator set equal to one in year $t$ if the firm is taken public or sold in $t$ through $t+2 .{ }^{19}$ However, not every exit is a success: 84 of the 332 exits have negative IRRs. ${ }^{20}$ To account for this, we code a second measure of exit success which captures exits that occur at a positive IRR. In either case, we look up to two years out because the effect of CEO turnover on the probability of exit need not be instantaneous; results for shorter horizons are reported in Section 6.

\subsection{Naïve and Reduced-form Models of Exit Performance}

Table 5 reports four naïve probits that treat CEO turnover as exogenous: One model each for exits and exits at a positive IRR, estimated with or without portfolio-firm effects. ${ }^{21}$ In all four cases, we find a negative relation between $\mathrm{CEO}$ turnover and performance. In column 1, for example, firing the CEO 'results' in a 7.4 percentage point reduction in the probability of exit over the next two years (from the

\footnotetext{
${ }^{18}$ Evidence from placebo models (Bertrand, Duflo, and Mullainathan (2004)) suggests that our standard errors are reasonably close to unbiased. We estimate the CEO turnover model for 1,000 random law-change dates and so obtain an estimate of the true error distribution from the data. Since the dates are random, we expect to incorrectly reject the true null at the $\alpha \%$ level in $\alpha \%$ of the trials. The simulations falsely reject the null at the $1 \%$ and $5 \%$ levels $1.8 \%$ and $6.0 \%$ of the time. The Table 3 , column 2 point estimate of 0.644 for the effect of law changes on CEO turnover exceeds 998 of the 1,000 simulated coefficients, giving a simulated $p$-value of 0.002 - nearly identical to the estimated $p$-value of 0.001 reported in Table 3 . ${ }^{19}$ By construction, every CEO dismissal must precede an exit or write-off, so there is no problem including exits in year $t$.

${ }^{20}$ Why not use the IRRs to measure performance directly? In a private equity setting, a firm's IRR does not vary annually - it can be computed only upon exit. If we were to model IRRs, the panel would hence collapse into a single cross-section and we could not use our instrument, which relies on time variation in the legal environment relative to the date of CEO turnover.

${ }^{21}$ We use random firm effects since fixed-effects probit suffers from a well-known incidental-parameters problem. Results from linear probability models, which can accommodate fixed effects, look very similar; see the Internet Appendix.
} 
unconditional probability of $41.1 \%$ ), all else equal. The negative sign is consistent with the expected selection problem: Boards intervene in badly managed or under-performing firms, so when we compare the exit rates of firms with and without intervention, we are likely picking up unobserved differences in CEO or firm quality rather than the effect of intervention.

The controls behave as expected. Firms that perform better relative to budget are more likely to be exited and to be exited at a positive IRR, as are larger deals. Staged deals are less likely to be exited, consistent with the interpretation that they are riskier. Favorable macroeconomic conditions (measured as real GDP growth) and reforms affecting a country's business environment (measured using the EBRD transition indicator) both improve a firm's exit chances. The three sets of year, industry, and country effects are each statistically significant, as are the portfolio-firm effects where included.

To solve the endogeneity problem evident from the negative naïve CEO turnover effect, we will now use law changes as an instrument. Before discussing the IV results, we check if law changes have a reduced-form effect on performance. Given the evidence in Section 4 that CEOs are more likely to be fired after governance reforms, there should be a positive reduced-form relation between law changes and performance, as long as CEO turnover improves performance. As Angrist and Krueger (2001) note, if we do not see the causal relation of interest in the reduced form, it is probably not there.

The four reduced-form probits, reported alongside the naïve estimates in Table 5, point to a strong, statistically significant reduced-form relation between the instrument and performance, for either exit measure and whether or not we include firm effects. Importantly, it has the expected positive sign: Law changes strengthening the power of the board over the CEO are associated with improved exit performance. As we show in the Internet Appendix, this remains true in linear probability models.

\subsection{Estimates of the Causal Effect of CEO Turnover on Exit Performance}

We can now estimate the causal effect of CEO turnover on performance using law changes as an instrument. The endogenous variable (CEO turnover) is of course binary, as is our measure of performance (whether the investment is exited rather than written off). There are two ways to estimate such a system. The first, going back to Maddala (1983, p. 118) and developed further in Greene (1998), uses a seemingly unrelated bivariate probit. In our case, this amounts to jointly estimating CEO turnover 
as in Table 3 with an exit performance model as shown in Table 5. Greene proves that this yields consistent and efficient estimates under the same identification assumptions as a linear model would. ${ }^{22}$

The second way to estimate this system follows Angrist (2001), who advocates using a simple 2SLS approach based on linear probability models in both stages. While linear probability models have the drawback that the coefficients can imply probabilities outside the unit interval and the marginal effects are often unrealistic, they have the advantage over probit models that they can accommodate fixed effects. We obtain similar results with either method and report both.

Columns 1 and 4 of Table 6 report probit results for exits and exits at a positive IRR. A likelihood ratio test rejects the null that the disturbances in the CEO turnover and exit equations are uncorrelated. This confirms that CEOs are fired endogenously and an instrument is needed. The correlation is negative, as expected, suggesting that boards intervene in lower-quality firms. Importantly, the effect of CEO turnover flips sign compared to the naïve models and the point estimates are statistically significant at the $1 \%$ level when standard errors are clustered by portfolio firm. (Clustering instead on country increases the significance to $p \leq 0.001$; see the Internet Appendix.) This provides direct and plausibly causal evidence of the beneficial effect of active monitoring: Once we instrument it, board intervention improves performance. The economic effects are large. Holding all covariates at their sample means, the marginal effect of the CEO turnover coefficient shown in column 1 implies that firing the CEO doubles the probability of exit over the next two years or, equivalently, reduces the probability of having to write the investment off by two-thirds. In column 4 , the probability of a profitable exit improves by a factor of 1.59. In sum, even though boards intervene in lower-quality firms, doing so makes a successful investment outcome significantly more likely.

Not surprisingly, poor managerial skill has a negative effect on performance $(p=0.028$ and $p=0.062$ in columns 1 and 4, respectively). To illustrate, the continued presence of a CEO the board deems incompetent reduces the chances of a successful investment outcome from $41.0 \%$ to $23.4 \%$ in column 1 . Since incompetence often leads to firing, according to Table 3, this suggests that failure (or inability) to get rid of a bad CEO increases the chances that the investment will have to be written off.

\footnotetext{
${ }^{22}$ For recent applications in finance, see Shivdasani and Song (2006) and Ljungqvist, Marston, and Wilhelm (2009).
} 


\subsection{Adding Portfolio-Firm Effects}

Might the positive effect of CEO turnover on subsequent performance be driven by omitted factors? The EBRD data lack information on the CEO's ownership and compensation or the board's quality and composition, each of which could affect both CEO turnover and performance. For example, CEOs with majority ownership may be both impossible to fire and associated with poor performance. One way to capture such omitted variables is to include firm effects in both equations. In the context of the bivariate probit, this means including a set of random firm effects that are allowed to be correlated across the intervention and performance equations (see Greene (2002, E17.5)). The resulting estimates, shown in columns 2 and 5 in Table 6 , suggest that omitted variables do not drive our results. The point estimates are similar in magnitude to those estimated without firm effects and continue to be highly significant.

Alternatively, we can follow Angrist (2001) and estimate simple two-stage linear probability models rather than bivariate probits. The main advantage of linear models is that they can accommodate firm fixed effects, though we then have to drop all time-invariant regressors, specifically the staging and privatization controls as well as the country and industry indicators. The results are shown in columns 3 and 6. Again, our causal inferences are entirely unaffected: CEO turnover is associated with a higher likelihood of subsequent exit while the presence of a CEO deemed incompetent has a negative effect.

\subsection{Performance Relative to Budget}

In addition to exit, we can also model performance relative to budget. We estimate standard OLS regressions treating the five-point performance score as a continuous variable. We relate the firm's score in year $t+1$ to CEO turnover in year $t$ and to a set of control variables dated $t-1$. When we estimate naïve OLS regressions without firm effects or with random or fixed firm effects, shown in columns 1 to 3 of Table 7, we find evidence that CEO turnover has a small, positive and at least marginally significant effect on subsequent performance. This contrasts with the negative effects we found in the naïve exit models shown in Table 5. Thus, the Table 7 models appear to be less biased. Still, the estimated magnitudes could be downward biased. The coefficients are fairly small, suggesting that CEO turnover improves performance by only between 0.183 and 0.342 on a five-point scale whose mean is 2.8 .

The reduced-forms, shown in columns 4-6, mirror those for exit performance: There is a positive 
and significant reduced-form relation between the instrument and performance relative to budget.

Columns 7-9 report IV models that treat intervention as endogenous, instrumented using the law changes. Because CEO turnover is a binary variable, column 7 is estimated as a Heckman (1978) treatment model. ${ }^{23}$ This increases the estimated intervention effect eight-fold relative to the corresponding naïve model in column 1. Specifically, forced CEO turnover now leads to a 1.579-point improvement on our five-point scale. The $t$-statistic in column 7 is 6.49 clustered by firm; clustered by country, it is 8.18 (see the Internet Appendix). Columns 8 and 9 include random and fixed firm effects, respectively. These specifications similarly yield substantially larger point estimates than their naïve counterparts, of $1.944(p=0.038)$ and $2.168(p=0.087)$, respectively.

Among the controls, firms whose performance in $t-1$ was poor due to 'bad luck' later perform better. This adds credence to this variable: Bad luck should not be persistent, so firms should bounce back later. Finally, firms run by managers who are deemed incompetent later perform significantly worse.

\subsection{Summary}

Whether we measure performance as exit or relative to budget, we get the same result: As long as we instrument it, CEO turnover has a large, positive, and significant effect on performance. This is echoed in the way fund managers comment on the beneficial effects of CEO turnover. For example:

"The turnaround under new management has been extremely impressive. From a disastrous 2002, when under former management there was a period of liquidation risk, [the company] has [re]turned to profit.”

We find strong evidence of a downward bias when estimating the effect of CEO turnover in naïve models. This appears to be due to a negative correlation between the disturbances in the intervention and performance equations, indicating that boards intervene in badly managed or poorly performing firms. Our instrument appears to do a good job breaking this endogeneity.

\subsection{Identification Concerns}

Before we can conclude that CEO turnover causally improves performance, we need to consider whether law changes are a valid instrument. Our identification strategy requires that law changes satisfy three conditions. They must affect CEO turnover, and we have already shown that they do. They must

\footnotetext{
${ }^{23}$ The normality assumption underlying the Heckman (1978) model may be violated, since the performance score has support on a bounded interval. Applying a standard logistic transform and re-estimating the Heckman model does not materially change our results (not tabulated), suggesting that normality is an acceptable approximation for these data.
} 
not correlate with omitted variables that themselves plausibly affect performance. And they must affect performance only through their effect on CEO turnover, not directly. It is clearly never possible to completely rule out violations of the last two conditions in general, but we can explore whether or not the data are consistent with particular violations. In this subsection, we first provide evidence that substantially restricts the set of potential omitted variables and then consider the plausibility of key alternative channels through which law changes might affect performance directly.

\subsubsection{Correlation with Omitted Variables}

In our setting, the main concern regarding omitted variables is that reforms correlate with unknown contemporaneous improvements in the local business environment, rather than capturing changes in board power. Three features of our tests alleviate this concern to some extent. First, governance reforms were staggered across countries. Thus, to bias our results, any omitted variable(s) would have to have coincided with each individual country's law change and so be country- and time-specific. Second, our models explicitly control both for a country's observed macroeconomic conditions (using GDP growth rates) and its reform progress (using the EBRD transition indicator). The latter is designed precisely to capture improvements in the business environment and is routinely used in the transition economics literature (e.g., Glaeser, Johnson, and Shleifer (2001)). Thus, any omitted variable that somehow happens to coincide with governance reforms must not already be captured by our controls and especially not by the EBRD transition indicator. Third, a closer look at the EBRD transition indicator reveals that governance reform did not obviously coincide with a noticeable acceleration of other reforms. Figure 3 graphs the transition indicator, separately for each country, relative to the year corporate governance was reformed. With the possible exception of Bulgaria, Georgia, and Slovenia (accounting for 26 of the 473 sample firms), all countries were on a smooth transition path when governance was reformed and there is no evidence of a structural break in local business conditions.

These controls notwithstanding, it is obviously impossible to rule out omitted-variable concerns completely in observational data. However, we can perform two indirect tests to see if such concerns appear well founded. The first addresses a specific shock that governance reform may have coincided with. Governance reform was often part of a broader overhaul of commercial law, affecting many 
aspects of business such as contracts, employment, and intellectual property, and not just board power. It is possible that the performance improvements we see in the data were caused by the overhaul of commercial law rather than by changes in board power. We can exploit a convenient feature of our data to shed further light on this possibility. Three sample countries - Croatia, Romania, and Russiaempowered boards to fire CEOs by amending their commercial law some years later. If governance reform simply picks up the beneficial effects of introducing commercial law, then the later governance amendments should have no reduced-form effect on performance in these three countries.

Columns 1 and 5 of Table 8 restrict the sample to the three amendment countries. Because Westernstyle corporate law had been adopted some years earlier, the law-change instrument isolates the effect of governance reform on performance. The probit point estimates confirm that reforming board power affects performance independently of the adoption of Western-style commercial law. They are positive and statistically significantly different from zero and the marginal effects are, if anything, somewhat larger than their counterparts in Table 5 where we include all 19 countries. ${ }^{24}$ Linear probability models, shown in the Internet Appendix, confirm this. While the sample used in this particular test covers only three countries, it is clear that these results do not contradict our identification strategy.

A second way to get at confounding effects is to place restrictions on the nature of the unobserved shock. If reforms simply proxy for omitted country-specific shocks, firms should see their performance improve regardless of the size of the fund's ownership position. But if reforms strengthen board power, as we assume, they should affect performance only when the fund lacks majority control. The reason is that a majority owner does not need a law change in order to take performance-improving decisions such as firing an incompetent CEO - he can fire the CEO at will. We thus test whether the performanceimproving effect of governance reforms is concentrated among firms whose funds are minority owners.

To do so, we interact law changes with an indicator variable for majority-owned firms using the reduced-form performance model introduced in Table 5. The results, shown in columns 2 and 6 of Table 8, support our identification strategy: Law changes have a positive and significant effect on subsequent

\footnotetext{
${ }^{24}$ Running a horse race between the adoption of Western-style corporate law and the adoption of laws strengthening the board in the whole sample, we find that the former has no significant effect on exits $(p=0.688)$ while the latter does $(p=0.01)$.
} 
exits only when the fund owns a minority stake. For majority-owned firms, the effect is essentially zero, economically and statistically. In column 2, for example, applying the Ai and Norton (2003) correction to calculate marginal effects for probit interaction coefficients, we find that law changes increase the likelihood of a subsequent profitable exit by 18.02 percentage points for minority-owned investments and by $18.02-17.99=0.03$ percentage points for majority-owned investments. Thus, the performanceimproving effect of law changes is concentrated among firms whose fund investors are minority owners, consistent with a board-power channel: A fund that has majority control does not need a law change in order to implement performance-improving decisions such as firing a CEO.

This evidence is difficult to square with the idea that the country simply experienced some generic positive development that coincided with a reform empowering boards to fire their CEOs. Whatever this development might be, it would have to exclusively affect the performance of minority-controlled firms. It is not obvious what kind of unobserved shock would fit this pattern.

\subsubsection{Exclusion Restriction: CEO Effort}

The exclusion restriction requires that law changes have no direct effect on performance and instead operate only through their effect on board power. A possible violation of this condition is that they might induce CEOs to improve performance merely by raising the threat of firing. For this effect to drive our finding that performance improves after CEO turnover, it would have to be the case that CEOs fear being fired for moral hazard reasons rather than for incompetence. After all, CEOs can surely change only their actions, not their skills, in response to an increased firing threat. However, the evidence in Table 3 shows that moral hazard plays no role in boards' firing decisions in our sample. Instead, boards fire CEOs they deem incompetent, consistent with boards having learnt the CEO's type - something the CEO cannot easily change in the short term. Moreover, as noted earlier, boards rarely even complain about moral hazard in our data, perhaps because CEO incentives generally work quite well in a private equity setting.

Still, let us assume that moral hazard plays a bigger role in our data than our evidence suggests. Then CEOs should reasonably adjust their behavior as soon as it is clear that reform is on its way rather than wait for the law to come into effect. This is testable: Performance should begin to improve once reform is first mooted in the local press. The results, shown in columns 3 and 7 of Table 8 , are 
unambiguous: Performance only improves once the law has changed, not when the press first reports that reform is on its way. Though indirect, this evidence makes it less likely that performance in our sample improves following CEO turnover simply because CEOs work harder to avoid being fired.

Nor is there any evidence that CEOs do, in fact, raise their game in response to governance reform. Focusing exclusively on firms affected by a law change, we split the sample into firms whose CEO will be fired in the two years following reform and those whose CEO will remain in post. If the story were a moral hazard one, then the CEOs who were later fired should be the ones who failed to raise their game in response to a law change. The data suggest otherwise. When reforms are announced, firms in neither group see any change in performance relative to budget and so are not statistically different from each other $(p=0.893)$. The same is true at enactment: The two groups see mean performance changes of 0.14 $(p=0.304)$ and $0.01(p=0.923)$, respectively, with an insignificant difference in differences $(p=0.511)$. Thus, CEOs do not appear to raise their game ahead of governance reform. ${ }^{25}$ In contrast, in the year after a CEO is actually fired, performance improves by an average of $0.6(p=0.041)$, in line with Table 7 .

Moreover, if boards were seriously concerned about moral hazard, we might expect them to restructure $\mathrm{CEO}$ incentive contracts when their power increases. After all, if governance mainly solves a moral hazard problem, greater board power should reduce the incentive pay a CEO needs to be offered (see Core et al. (1999)). However, only six sample firms change the incentive contract of an incumbent CEO and the timing of these changes does not coincide with governance reform. This suggests that the tradeoff between board power and incentive contracts is not first order in our data, possibly because moral hazard is not the primary governance concern in private-equity backed companies.

Before we turn to another potential violation of the exclusion restriction, we offer a reality check on our identification strategy. In Section 4.2, we showed that governance reforms that require a charter amendment before boards can fire a CEO have no effect on CEO turnover. This is as expected, since none of our sample firms amends its charter during the sample period. By the same token, this type of reform should not affect performance either. Columns 4 and 8 of Table 8 confirm that this is indeed so.

\footnotetext{
${ }^{25}$ Law changes may simultaneously prompt boards to set more demanding budgets and CEOs to raise their game, resulting in no overall change in performance relative to budget. However, we find no evidence that profit or sales targets are changed differently around law changes than at other times. Modeling how budgets evolve over time is beyond the scope of this paper.
} 
While governance reforms that empower the board to fire a CEO at will have a large and significant reduced-form effect on subsequent exit performance, reforms that require a charter amendment do not ( $p=0.446$ and $p=0.571$ in columns 4 and 8 , respectively).

\subsubsection{Exclusion Restriction: Fund Investment Behavior}

A second potential violation of the exclusion restriction is the possibility that the private equity funds in our sample may have changed investment strategy in anticipation of, or in response to, reform. Specifically, suppose post-reform funds invest in firms whose performance they think they can improve through active monitoring. Such a selection effect, while entirely consistent with a causal interpretation of the performance-improving effect of CEO turnover shown in Tables 6 and 7, would lead us to overestimate its magnitude by oversampling firms for which firing the CEO will lead to better performance.

A simple way to test this story is to restrict the sample to investments made before the law changes i.e., before any potential change in strategy - and compare the estimated effects to those obtained in the full sample. Table 9 reports the results. For ease of comparison, Panel A reproduces our full-sample estimates, that is, the coefficients of the effect of CEO turnover on performance from the nine structural specifications reported in Table 6 (exit rates) and Table 7 (performance relative to budget). To keep the size of Table 9 manageable, we suppress all other coefficient estimates. Panel B restricts the sample to investments made two or more years before reform in the country in question, just as we did in Table 4. Alternatively, Panel C restricts the sample to investments made before reform was first rumored. Each restricted sample contains around two-thirds of the firm-years of the full estimation sample.

Every one of the 18 coefficient estimates in Panels B and C is positive and statistically significant (mostly at the $1 \%$ level or better). Thus, we continue to find that CEO turnover is followed by better performance, both in terms of exit rates (as in Table 6) and in terms of performance relative to budget (as in Table 7), even among pre-reform investments. Second, there is only modest evidence in favor of the potential upward bias that would result from the putative change in sample funds' investment selection criteria around law changes. While twelve of the 18 point estimates are indeed smaller in the two restricted samples than in the full sample, the differences are quite small and not significant. Overall, these tests do not suggest that funds change their investment behavior, at least not in ways that 
impact the estimated CEO turnover-performance relation.

We can draw one further inference from these tests. The restricted samples basically exclude firms that are not affected by a change in board power during their time in our sample (because they exclude firms that received funding only after a law change appeared on the horizon). Table 9 shows that excluding such firms has no significant effect on our finding that performance improves following CEO turnover. This confirms our earlier conclusion that we can safely include the full sample of firms in our models in order to improve the efficiency with which the effects of some control variables are estimated.

\subsubsection{Exclusion Restriction: Other Key Concerns}

We briefly discuss three further possible challenges to our identification strategy. First, governance reform may have resulted in better qualified directors being appointed to boards, which in turn may have led to better board decisions and thus performance improvements independently of CEO changes. While this may be true in the wider economy, this alternative channel is easy to dismiss for our private equitybacked firms. According to the EBRD monitoring reports, board composition does not change around governance reform and indeed changes very little at other times. Moreover, the key board director - the private equity fund manager - is present on the board in every panel year.

Second, reform may have increased the supply of equity or debt, loosening financial constraints and so perhaps leading to performance improvements. According to the EBRD monitoring reports, the supply of equity to our sample firms is unchanged around law changes. Data for the supply of debt is not available at the firm-level, so we instead regress a country's domestic credit to the private sector relative to GDP on the law change indicator, year effects (to capture trends), and country fixed effects, allowing for auto-correlation in the dependent variable. We find no evidence of an increased supply of debt around governance reforms at the macro level. The point estimate suggests that domestic credit/GDP is only $0.18 \%$ higher after reform, with a $t$-statistic of 0.06 . This represents a negligible increase relative to the average annual change in domestic credit/GDP of $2.4 \%$ per year.

Finally, the timing of reforms may have been influenced by lobbying which in turn may correlate with performance. This seems implausible. Reform was aided by the European Commission and the World Bank which provided technical assistance on their own timetables and according to their own 
resource constraints. They are unlikely to have been lobbied by our relatively small sample firms. ${ }^{26}$

\subsection{Robustness Tests}

Table 10 reports variations on the IV specifications reported in Tables 6 (exit) and 7 (performance relative to budget). To save space, we report only the CEO turnover coefficients. As before, standard errors are clustered by firm. (The Internet Appendix reports alternative results clustered by country.)

Panel A explores whether the results are sensitive to the horizon over which exit is measured. So far, we have related exit in years $t$ to $t+2$ to intervention in year $t$. When we shorten the horizon to $t$ to $t+1$, we continue to find that CEO turnover improves the probability of exit, though the effect is generally weaker. When we shorten the horizon further, to simply $t$, the effect disappears (not tabulated). This suggests, not unreasonably, that it takes time for a new CEO to improve a firm's performance.

Previously, we constrained the effect of reform on CEO turnover to be constant across countries and time by using a simple intercept shift in the reform year. In Panel B, we allow the effect to vary over time by replacing the instrument with the set of five indicator variables introduced in Table 4 . In Panel C, we allow the effect to vary across countries by including country-level reform indicators. In either case, the coefficients estimated for the effect of CEO turnover on performance are barely changed.

\section{Conclusions}

Data constraints mean that corporate governance is usually a black box. We exploit unique and detailed data on board actions, expectations, and beliefs about CEO ability for a large sample of privately-held firms from countries that experienced large and plausibly exogenous shocks to their corporate governance rules. This allows us to investigate how boards of directors monitor management, under what circumstances they fire CEOs, and whether these actions improve performance.

We find that boards update their beliefs about CEO ability in part based on how the firm performs relative to their expectations and that CEOs are fired when the firm underperforms these expectations. That boards respond to hard information such as performance data is perhaps not surprising. But we also show that soft information plays an important role: CEOs are especially likely to be fired when evidence

\footnotetext{
${ }^{26}$ We can formally test lobbying and other reverse-causality stories by replacing the instrument with the set of five timevarying indicators from Table 4. Consistent with the claim that the timing of reform is orthogonal to the performance of sample firms, we find no evidence that future law changes affect performance, while past law changes do (not tabulated).
} 
has mounted that they are incompetent. Increases in board power following governance reforms lead to higher CEO turnover and greater reliance on soft over hard information. Using these exogenous changes in board power as an instrument, we show that CEO turnover improves subsequent performance. This in turn suggests that boards' assessments of CEO ability contain meaningful information, rather than being completely subjective or reflecting self-confirmation bias (i.e., the tendency to favor information that confirms one's preconceptions regardless of whether the information is true).

Our results suggest that monitoring - especially gathering soft information - can be valuable. This provides a justification for the incomplete-contracts explanation for why we need boards: Soft information is by definition nonverifiable and so cannot be contracted upon. It is thus important for someone - a board or a large shareholder - to collect soft information and to have the power to act on it.

We interpret our findings to suggest that monitoring largely serves a learning purpose, at least in private equity settings such as ours. When a CEO is hired, his true ability and the match between his skills and the firm's needs are not perfectly known. Over time, the board collects information and, once it has learnt his true ability, takes corrective action if necessary. This view of the board's role echoes models of learning and worker turnover in labor economics, such as Harris and Holmström (1982) and Jovanovic (1979). It contrasts with the received view in much of the governance literature, which, as Tirole (2001) notes, mainly focuses on moral hazard problems rather than learning. ${ }^{27}$ Our finding that CEOs are frequently fired for incompetence and not for moral-hazard behavior (which anyway is rare in our data) confirms that learning about CEO ability plays an important part in corporate governance.

Our results identify the average effect of active monitoring on corporate performance. This could disguise interesting variation across funds in the quality of their corporate governance. For example, some fund managers may be better than others at identifying poorly performing CEOs, or at persuading fellow board members to replace such CEOs. Moreover, there may be learning in the sense that fund managers may discover how best to adapt their governance practices to a transition-economy context. We leave these interesting questions for future research.

\footnotetext{
${ }^{27}$ Hermalin and Weisbach (1998), Dominguez-Martinez, Swank, and Visser (2008), and Taylor (2010) are notable exceptions.
} 


\section{References}

Acharya, Viral, Moritz Hahn, and Conor Kehoe, 2008, Corporate governance and value creation: Evidence from private equity, Unpublished working paper, NYU.

Adams, Renée, Benjamin E. Hermalin, and Michael S. Weisbach, 2008, The role of boards in corporate governance: A conceptual framework and survey, NBER Working Paper No. 14486.

Ai, Chunrong, and Edward C. Norton, 2003, Interaction terms in logit and probit models, Economics Letters 80, 123-129.

Angrist, Joshua, 2001, Estimation of limited endogenous variable models with dummy endogenous regressors: Simple strategies for empirical practice, Journal of Business and Economic Statistics 19, $2-16$.

Angrist, Joshua, and Alan B. Krueger, 2001, Instrumental variables and the search for identification: From supply and demand to natural experiments, Journal of Economic Perspectives 15, 69-85.

Bertrand, Marianne, and Sendhil Mullainathan, 2003, Enjoying the quiet life? Corporate governance and managerial preferences, Journal of Political Economy 111, 1043-1075.

Bertrand, Marianne, Esther Duflo, and Sendhil Mullainathan, 2004, How much should we trust difference in difference estimates?, Quarterly Journal of Economics 119, 249-275.

Bottazzi, Laura, Marco Da Rin, and Thomas Hellmann, 2008, Who are the active investors?, Journal of Financial Economics 89, 488-512.

Core, John E., Robert W. Holthausen, and David F. Larcker, 1999, Corporate governance, chief executive officer compensation, and firm performance, Journal of Financial Economics 51, 371-406.

Cornelissen, Thomas, and Katja Sonderhof, Partial effects in logit and probit models with a triple dummy-variable interaction term, The Stata Journal 9, 571-583.

Coughlan, Anne T., and Ronald M. Schmidt, 1985, Executive compensation, management turnover, and firm performance, Journal of Accounting and Economics 7, 43-66.

Denis, David J., and Diane K. Denis, 1995, Firm performance changes following top management dismissals, Journal of Finance 50, 1029-1057.

Dinneen, Patricia, 2004, Emerging Markets Private Equity Performance Update, available electronically at http://www.ifc.org/ifcext/cfn.nsf/AttachmentsByTitle/Patricia+Dinneen/\$FILE/Panel4PatriciaDinneen.pdf.

Djankov, Simeon, and Peter Murrell, 2002, Enterprise restructuring in transition: A quantitative survey, Journal of Economic Literature 40, 739-792.

Dominguez-Martinez, Silvia, Otto H. Swank, and Bauke Visser, 2008, In defense of boards, Journal of Economics and Management Strategy 17, 667-682.

Fee, C. Edward, and Charles J. Hadlock, 2004, Management turnover across the corporate hierarchy, Journal of Accounting and Economics 37, 3-38.

Glaeser, Edward, Simon Johnson, and Andrei Shleifer, 2001, Coase vs. the Coasians, Quarterly Journal of Economics 116, 853-899.

Gompers, Paul A., 1995, Optimal investment, monitoring, and the staging of venture capital, Journal of Finance 50, 1461-1490.

Gompers, Paul A., and Josh Lerner, 1998, What drives fundraising?, Brookings Papers on Economic Activity: Microeconomics, 149-92. 
Gompers, Paul A., and Josh Lerner, 2000, Money chasing deals? The impact of fund inflows on private equity valuations, Journal of Financial Economics 55, 281-325.

Greene, William H., 1998, Gender economics courses in liberal arts colleges: Further results, Journal of Economic Education 29, 291-300.

Greene, William H., 2002, Limdep Version 8.0 - Econometric Modeling Guide, Volume 1 (Plainview NY, Econometric Software Inc.).

Harris, Milton, and Bengt Holmström, 1982, A theory of wage dynamics, Review of Economic Studies 49, 315-333.

Heckman, James J., 1978, Dummy endogenous variables in a simultaneous equation system, Econometrica 46, 931-959.

Hellmann, Thomas, and Manju Puri, 2000, The interaction between product market and financing strategy: The role of venture capital, Review of Financial Studies 13, 959-984.

Hellmann, Thomas, and Manju Puri, 2002, Venture capital and the professionalization of start-up firms: Empirical evidence, Journal of Finance 57, 169-197.

Hermalin, Benjamin E., and Michael S. Weisbach, 1998, Endogenously chosen boards of directors and their monitoring of the CEO, American Economic Review 88, 96-118.

Hochberg, Yael, Alexander Ljungqvist, and Yang Lu, 2007, Whom you know matters: Venture capital networks and investment performance, Journal of Finance 62, 251-301.

Huson, Mark, Paul Malatesta, and Robert Parrino, 2004, Managerial succession and firm performance, Journal of Financial Economics 74, 237-275.

Jenter, Dirk, and Fadi Kanaan, 2008, CEO turnover and relative performance evaluation, Unpublished working paper, Stanford University.

Jovanovic, Boyan, 1979, Job matching and the theory of turnover, Journal of Political Economy 87 , 972-990.

Kaplan, Steven N., and Bernadette A. Minton, 2006, How has CEO turnover changed? Increasingly performance sensitive boards and increasingly uneasy CEOs, Unpublished working paper, University of Chicago.

Kaplan, Steven N., Mark M. Klebanov, and Morten Sørensen, 2010, Which CEO characteristics and abilities matter?, Journal of Finance, forthcoming.

Kim, Yungsan, 1996, Long-term firm performance and chief executive turnover: An empirical study of the dynamics, Journal of Law, Economics, and Organization 12, 480-496.

Kortum, Samuel, and Josh Lerner, 2000, Assessing the contribution of venture capital to innovation, RAND Journal of Economics 31, 674-692.

Kumar, Praveen, and K. Sivaramakrishnan, 2008, Who monitors the monitor? The effect of board independence on executive compensation and firm value, Review of Financial Studies 21, 13711401.

La Porta, Rafael, Florencio Lopez-de-Silanes, and Andrei Shleifer, 2008, The economic consequences of legal origins, Journal of Economic Literature 46, 285-332.

Levitt, Steven D., 1996, The effect of prison population size on crime rates: Evidence from prison overcrowding litigation, Quarterly Journal of Economics 111, 319-351.

Ljungqvist, Alexander, Felicia Marston, and William J. Wilhelm, 2009, Scaling the hierarchy: How and why investment banks compete for syndicate co-management appointments, Review of Financial Studies 22, 3977-4007. 
Maddala, G.S., 1983, Limited-Dependent and Qualitative Variables in Econometrics (Cambridge, Cambridge University Press).

Monfardini, Chiara, and Rosalba Radice, 2008, Testing exogeneity in the bivariate probit model: A Monte Carlo study, Oxford Bulletin of Economics and Statistics 70, 271-282.

Petersen, Mitchell, 2004, Information: Hard and soft, Unpublished working paper, Northwestern University.

Popov, Alexander, and Peter Roosenboom, 2009, On the real effects of private equity investments: Evidence from new business creation, Working Paper No. 1078, European Central Bank.

Shleifer, Andrei, and Robert W. Vishny, 1986, Large shareholders and corporate control, Journal of Political Economy 94, 461-488.

Shleifer, Andrei, and Robert W. Vishny, 1997, A survey of corporate governance, Journal of Finance 52, 737-783.

Shivdasani, Anil, and Wei-Ling Song, 2006, Breaking down the barriers: Banking deregulation and underwriting incentives, Unpublished working paper, University of North Carolina, Chapel Hill.

Sørensen, Morten, 2007, How smart is smart money? An empirical two-sided matching model of venture capital, Journal of Finance 62, 2725-2762.

Staiger, Douglas, and James H. Stock, 1997, Instrumental variables regression with weak instruments, Econometrica 65, 557-586.

Taylor, Lucian A., 2010, Why are CEOs rarely fired? Evidence from structural estimation, Journal of Finance, forthcoming.

Tirole, Jean, 2001, Corporate governance, Econometrica 69, 1-35.

Tirole, Jean, 2006, The Theory of Corporate Finance (Princeton, Princeton University Press).

Warner, Jerold B., Ross L. Watts, and Karen H. Wruck, 1988, Stock prices and top management changes, Journal of Financial Economics 20, 461-492.

Weisbach, Michael S., 1988, Outside directors and CEO turnover, Journal of Financial Economics 20, 431-460.

Yefymenko, Anatoliy, 2009, Corporate governance under Ukraine's new Joint Stock Company Law, Unpublished working paper, Kyiv Taras Shevchenko University.

World Bank, 2005, Corporate Governance Country Assessment: Azerbaijan, July 2005 (Washington, D.C.: World Bank Group). Available at http://www.worldbank.org/ifa/rosc_cg.html, accessed August 2008. 
Figure 1. Forced CEO Turnover Around Corporate Governance Reform.

The graph shows the annual incidence of forced CEO turnover. Time on the horizontal axis is measured relative to the year in which the country in question reformed its corporate governance laws by giving boards the statutory power to dismiss CEOs, denoted year 0 ; see Table 2 for a list of these dates. Countries without a law change, or where the law change only empowered the shareholders' meeting to amend the corporate charter to delegate the power to dismiss the CEO, are excluded. Year -5 includes prior years; year 5 includes later years.

Annual forced CEO turnover rate

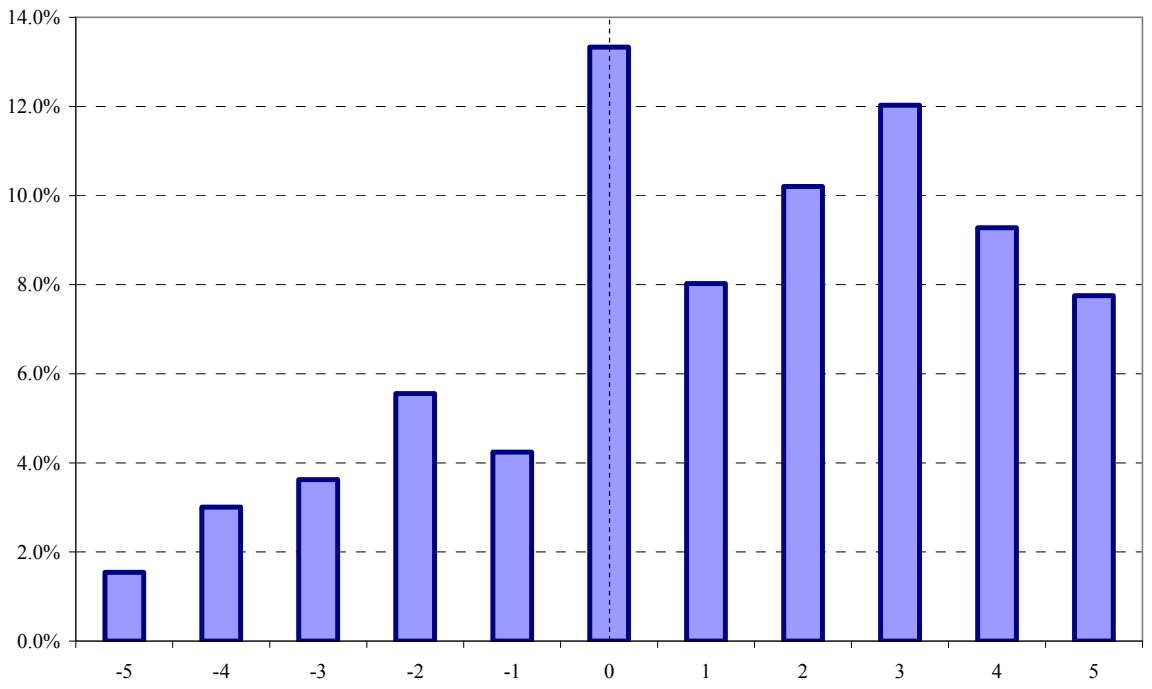

Figure 2. CEO Competence Around Corporate Governance Reform.

The EBRD regularly reviews the performance of each portfolio firm, resulting in a monitoring report based on both quantitative and qualitative criteria. The graph shows the annual incidence of a monitoring report mentioning that a fund manager privately viewed the CEO as incompetent. (Some CEOs are recorded as being incompetent repeatedly. Results are unaffected if we focus instead on unique CEOs.) Time on the horizontal axis is measured relative to the year in which the country in question reformed its corporate governance laws by giving boards the statutory power to dismiss CEOs, denoted year 0; see Table 2 for a list of these dates. Countries without a law change, or where the law change only empowered the shareholders' meeting to amend the corporate charter to delegate the power to dismiss the CEO, are excluded. Year -5 includes prior years; year 5 includes later years.

CEO viewed as incompetent

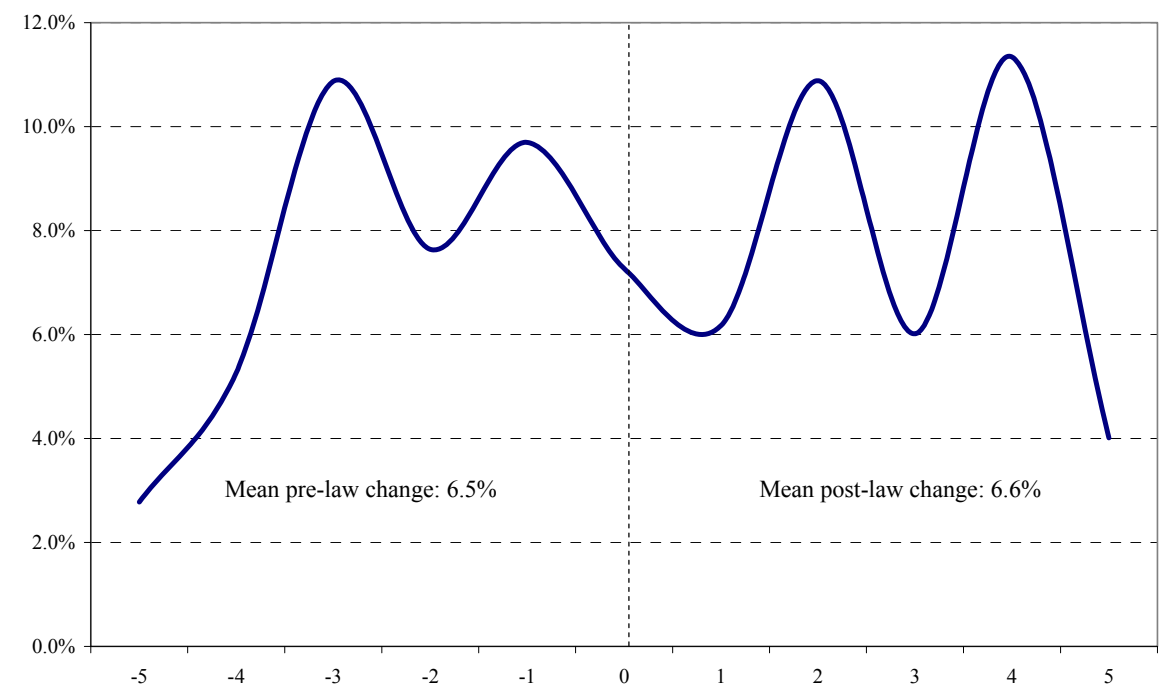




\section{Figure 3. Country-level Changes in Business Environment Around Corporate Governance Reform.}

The graphs show the annual level of the EBRD transition indicator around corporate governance reform for each sample country except Azerbaijan (which did not reform its corporate governance laws). Time on the horizontal axis is measured relative to the year in which the country in question reformed its corporate governance laws, denoted year 0 ; see Table 2 for a list of these dates. The EBRD transition indicator measures progress towards a market economy and is published annually. It is a composite of nine indices measuring progress in areas such as restructuring, securities markets, banking reform, and competition policy. It varies from 1 (centrally planned economy) to 4.33 (fully functioning market economy). The data are available at http://www.ebrd.com/pages/research/analysis/forecasts.shtml (see file sci.xls)
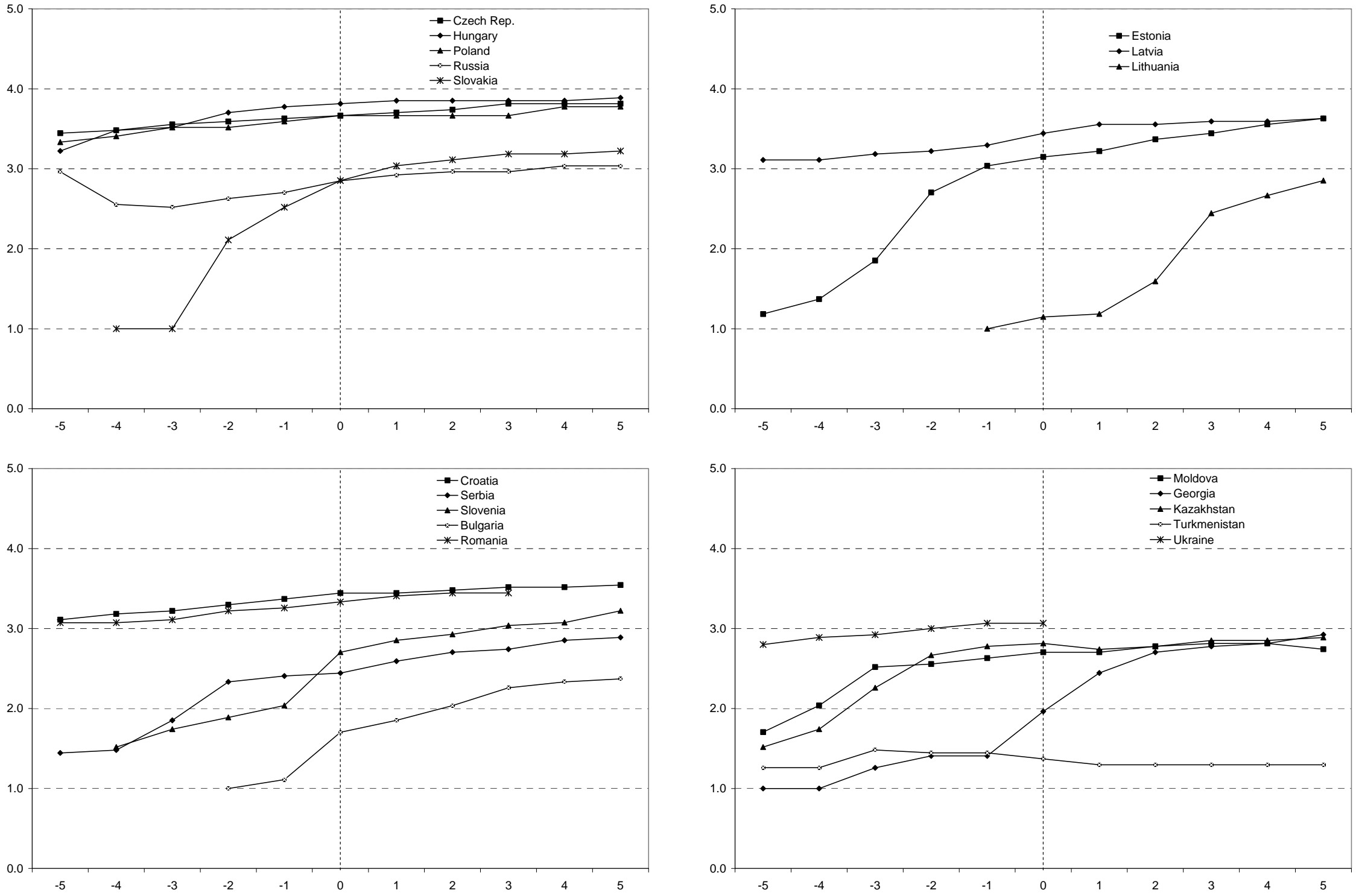
Table 1. Sample Overview.

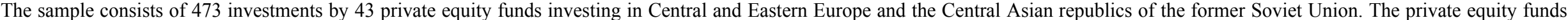

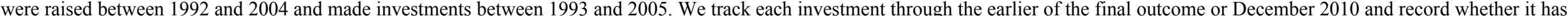

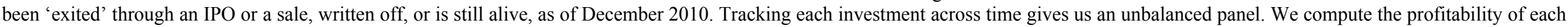

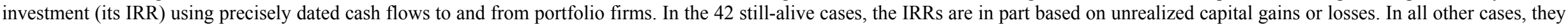

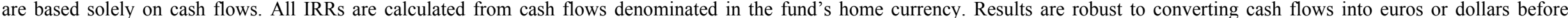
computing IRRs. We report equal-weighted mean IRRs. The value-weighted mean IRR across the 19 countries, weighted by the size of each investment in euros, is $14.8 \%$.

\begin{tabular}{|c|c|c|c|c|c|c|c|c|c|c|c|c|c|c|c|c|c|c|}
\hline \multirow[b]{2}{*}{ country } & \multicolumn{14}{|c|}{ Number of investments by year of initial investment } & \multicolumn{3}{|c|}{ Percent of sample that are } & \multirow{2}{*}{$\begin{array}{r}\text { Mean } \\
\text { IRR } \\
(\%)\end{array}$} \\
\hline & 1993 & 1994 & 1995 & 1996 & 1997 & 1998 & 1999 & 2000 & 2001 & 2002 & 2003 & 2004 & 2005 & Total & exited & $\begin{array}{r}\text { written } \\
\text { off }\end{array}$ & $\begin{array}{r}\text { still } \\
\text { alive }\end{array}$ & \\
\hline Azerbaijan & & & & & & & 1 & & & & & & & 1 & 0.0 & 100.0 & 0.0 & -100.0 \\
\hline Bulgaria & & & & 1 & 3 & & 2 & & 2 & & 1 & 8 & & 17 & 94.1 & 5.9 & 0.0 & 54.1 \\
\hline Croatia & & & & & & 1 & 1 & 2 & 3 & 2 & & 3 & & 12 & 66.7 & 8.3 & 25.0 & -7.8 \\
\hline Czech Republic & 3 & 5 & 5 & 1 & 4 & 4 & 8 & 9 & 2 & 2 & & & 1 & 44 & 75.0 & 22.7 & 2.3 & 29.6 \\
\hline Estonia & & & & 2 & & 4 & 1 & 1 & 1 & & 3 & 2 & 1 & 15 & 73.3 & 6.7 & 20.0 & 25.2 \\
\hline Georgia & & & & 1 & & & & & & 1 & & & & 2 & 100.0 & 0.0 & 0.0 & 15.3 \\
\hline Hungary & 1 & 2 & 3 & 6 & 7 & 11 & 6 & 8 & 6 & 3 & 2 & 4 & & 59 & 61.0 & 23.7 & 15.3 & 5.1 \\
\hline Kazakhstan & & & & & & 1 & 2 & & & & & & & 3 & 100.0 & 0.0 & 0.0 & 54.8 \\
\hline Latvia & & & & & & & & & & 1 & 1 & 3 & 2 & 7 & 14.3 & 14.3 & 71.4 & -7.9 \\
\hline Lithuania & & & & 2 & 1 & 2 & 4 & 1 & 2 & & & 1 & 2 & 15 & 53.3 & 40.0 & 6.7 & -17.4 \\
\hline Moldova & & & & & & & & & & & & 1 & & 1 & 100.0 & 0.0 & 0.0 & 155.9 \\
\hline Poland & 10 & 12 & 14 & 14 & 20 & 12 & 16 & 26 & 14 & 8 & 12 & 5 & 8 & 171 & 73.1 & 22.8 & 4.1 & -3.7 \\
\hline Romania & & & & 6 & & 6 & 8 & 2 & 2 & & 1 & 1 & 4 & 30 & 93.3 & 3.3 & 3.3 & 22.7 \\
\hline Russia & & 9 & 18 & 11 & 6 & 5 & & 4 & 9 & 5 & 3 & 4 & 1 & 75 & 57.3 & 30.7 & 12.0 & -3.7 \\
\hline Serbia Montenegro & & & & & & & & & & & 2 & & & 2 & 0.0 & 0.0 & 100.0 & -24.2 \\
\hline Slovakia & & & & & & 1 & & 4 & 5 & & & 1 & 1 & 12 & 83.3 & 8.3 & 8.3 & 5.4 \\
\hline Slovenia & & & & & & & & 1 & & & & & & 1 & 100.0 & 0.0 & 0.0 & 23.3 \\
\hline Turkmenistan & & & 1 & & & 1 & 1 & 1 & 1 & & & & & 5 & 100.0 & 0.0 & 0.0 & 44.6 \\
\hline Ukraine & & & & & 1 & & & & & & & & & 1 & 100.0 & 0.0 & 0.0 & 11.7 \\
\hline All countries & 14 & 28 & 41 & 44 & 42 & 48 & 50 & 59 & 47 & 22 & 25 & 33 & 20 & 473 & 70.2 & 20.9 & 8.9 & 6.4 \\
\hline
\end{tabular}


Table 2. Overview of Legal Changes Strengthening Boards of Directors in Central and Eastern Europe and in Central Asia.

The table lists legal changes strengthening the power of boards of directors over their CEOs. Most countries in our sample adopted the German system of a dual board structure, consisting of a management board and a supervisory board. In the text, we use the term 'board' as a short-hand for the supervisory board. Governance reforms come in two forms. Boards can either be given statutory power to dismiss the CEO without a shareholder vote or the law can permit the shareholders' meeting to delegate its power to dismiss the CEO to the board through an amendment to the corporate charter. In addition to the laws themselves, we have consulted the following sources: EBRD Corporate Governance Legislation Assessment Project, 2007 (http://www.ebrd.com/pages/sector/legal/corporate/assessment.shtml); EBRD Country Strategy Overview (http://www.ebrd.com/pages/country.shtml); World Bank Reports on the Observance of Standards \& Codes (http://www.worldbank.org/ifa/rosc cg.html); International Law Office (http://www.internationallawoffice.com); International Financial Law Review (http://www.iflr.com/Countries.aspx); OECD Corporate Governance Regional Roundtables (www.oecd.org/daf/corporateaffairs/roundtables); Doing Business country reports (http://www.doingbusiness.org); Federation of Euro-Asian Stock Exchanges (http://www.feas.org/MemberIndex.cfm); "New Joint Stock Company Law in Kazakhstan" by V.V. Markov (http://rusenergylaw.ru/2-2003/kaz13.html); the EBRD's legal journal, Law in Transition (http://www.ebrd.com/pages/research/publications/newsletters/archive/archive.shtml); "Corporate Governance and Securities Market Legislation in Transition" by G.P. Cigna (Journal of International Banking and Financial Law 21:11); "Guide to the Russian Law on Joint Stock Companies" by B. Black, R. Kraakman, and A. Tarassova (Kluwer Law International, 1998, The Hague); and Yefymenko (2009). We are grateful to Gian Piero Cigna, Senior Counsel of the EBRD, for expert advice.

\begin{tabular}{|c|c|c|c|c|c|c|c|c|c|c|}
\hline Country & $\begin{array}{l}\text { Year of } \\
\text { corporate } \\
\text { governance } \\
\text { reform } \\
\end{array}$ & Name of law & $\begin{array}{l}\text { Part of law } \\
\text { pertaining to } \\
\text { board powers }\end{array}$ & $\begin{array}{l}\text { Board is } \\
\text { given } \\
\text { statutory } \\
\text { power to } \\
\text { dismiss } \\
\text { CEO? }\end{array}$ & $\begin{array}{l}\text { Shareholder } \\
\text { meeting can } \\
\text { amend corporate } \\
\text { charter to } \\
\text { delegate power to } \\
\text { dismiss CEO to } \\
\text { the board? }\end{array}$ & $\begin{array}{l}\text { Power to } \\
\text { dismiss CEO } \\
\text { brought in by } \\
\text { amendment to } \\
\text { previously } \\
\text { enacted } \\
\text { corporate law? }\end{array}$ & $\begin{array}{l}\text { Number } \\
\text { of firms }\end{array}$ & $\begin{array}{c}\text { Total } \\
\text { number of } \\
\text { firm-years }\end{array}$ & $\begin{array}{c}\text { Number } \\
\text { of CEO } \\
\text { dis- } \\
\text { missals }\end{array}$ & $\begin{array}{c}\text { Percent } \\
\text { of which } \\
\text { occurred } \\
\text { post-law } \\
\text { change }\end{array}$ \\
\hline Azerbaijan & - & - & - & - & - & - & 1 & 4 & 1 & 0 \\
\hline Bulgaria & 1991 & Commercial Act & Article 241 & Yes & & & 17 & 79 & 8 & 100 \\
\hline Croatia & 2004 & Companies Act & Section 204 & Yes & & Yes & 12 & 63 & 4 & 75 \\
\hline Czech Rep. & 2001 & Commercial Law & Article 194 & & Yes & & 44 & 250 & 14 & 50 \\
\hline Estonia & 1995 & Commercial Code & Sections 308,309 & Yes & & & 15 & 83 & 4 & 100 \\
\hline Georgia & 1995 & Law on Entrepreneurs & Article 55.8 & Yes & & & 2 & 8 & 1 & 100 \\
\hline Hungary & 1998 & Act on Company Law & Section 37.1 & & Yes & & 59 & 332 & 31 & 84 \\
\hline Kazakhstan & 1998 & Law on Joint Stock Companies & Article 62 & Yes & & & 3 & 12 & 0 & \\
\hline Latvia & 2002 & Commercial Law & Section 292 & Yes & & & 7 & 40 & 4 & 100 \\
\hline Lithuania & 1990 & Law on Stock Corporations & Article 25.1 & Yes & & & 15 & 63 & 4 & 100 \\
\hline Moldova & 1997 & Joint Stock Company Law & Article 50.4 & & Yes & & 1 & 4 & 0 & \\
\hline Poland & 2001 & Code of Commercial Companies & Article 368.4 & Yes & & & 171 & 990 & 75 & 81 \\
\hline Romania & 2006 & Company Law & Article 153 & Yes & & Yes & 30 & 175 & 8 & 0 \\
\hline Russia & 2002 & Federal Law on Joint Stock Cos. & Articles 48,65 & Yes & & Yes & 75 & 448 & 23 & 74 \\
\hline Serbia-MN & 2004 & Companies Act & Article 322 & Yes & & & 2 & 10 & 1 & 100 \\
\hline Slovakia & 1992 & Commercial Code & Article $187(1)$ & & Yes & & 12 & 63 & 2 & 100 \\
\hline Slovenia & 1993 & Companies Act & Article 250 & Yes & & & 1 & 7 & 1 & 100 \\
\hline Turkmenistan & 1999 & Joint-Stock Companies Law & Article 48 & & Yes & & 5 & 27 & 0 & \\
\hline Ukraine & 2009 & Law on Joint-Stock Companies & Paragraph 52 & Yes & & & 1 & 4 & 0 & \\
\hline All countries & & & & & & & 473 & 2,662 & 181 & 77 \\
\hline
\end{tabular}




\section{Table 3. Evolution of Board Beliefs and Determinants of Board Intervention.}

The sample consists of an unbalanced annual panel of 473 firms which we observe from the year of the initial investment to the year of exit or write-off or through 2010, whichever is earlier. Column 1 studies the evolution of the board's beliefs about the CEO's competence. The tests reported in columns 2-9 focus on the determinants of board intervention, i.e., the removal of an executive (columns 2-8) or actions to strengthen the management team by hiring additional senior managers (column 9). The focus in columns 2-7 is on CEO turnover, while column 8 models dismissals of junior managers (i.e., any named executive below the level of the CEO). The table reports probit coefficients. Similar results, reported in the Internet Appendix, obtain using linear probability models. Note that the models in columns 6 and 7 include interaction effects. The coefficients and standard errors of interaction terms in nonlinear models such as probit have to be interpreted with care since they do not measure the required cross-partial derivative (see Ai and Norton (2003)). We report the correct marginal effects of the interaction terms in the text. The explanatory variables are listed in the table and defined further in Section 3. The law change variable equals one if at the beginning of year $t$, the law in country $k$ gives the firm's board the power to dismiss the CEO. Table 2 provides details of the staggered adoption of such laws in the 19 countries in our sample. We will later use law changes as an instrumental variable when we estimate the effect of CEO turnover on company performance. Thus, the CEO turnover models in columns 2-7 report the first stage of our subsequent instrumented performance models. The Staiger-Stock (1997) test is a Wald test of the null hypothesis that the law change variable does not correlate with board interventions. This is a standard test of weak instruments. It has a critical value of 10 in an $F$-test. (While we report a $\chi^{2}$ statistic with one degree of freedom instead of an $F$-test, for our sample size, $\chi^{2} \approx F$.) All specifications include country, industry, and year effects. Column 3 includes random portfolio-firm effects to control for unobserved heterogeneity. These are not statistically significant $(p=0.196)$. Linear probability models, which can accommodate firm fixed effects, are reported in the Internet Appendix. The number of observations is 2,103 except in column 4, where we restrict the sample to the 1,220 firm-years with lagged performance at or above plan (i.e., a performance score of 3 or better on the EBRD's five-point scale). Standard errors are reported in italics beneath the coefficient estimates. They are clustered on portfolio firm. See the Internet Appendix for specifications where we cluster the standard errors on country instead. We use ${ }^{* * *},{ }^{* *}$, and ${ }^{*}$ to denote significance at the $1 \%, 5 \%$, and $10 \%$ level (two-sided), respectively. "n.m." in columns 6 and 7 denotes "not meaningful." 
Table 3. Continued.

\begin{tabular}{|c|c|c|c|c|c|c|c|c|c|}
\hline & \multirow{3}{*}{$\begin{array}{c}=1 \text { if CEO } \\
\text { viewed as } \\
\text { incompetent } \\
(1)\end{array}$} & \multicolumn{7}{|c|}{ Dependent variable $=1$ if the board fires $\ldots$} & \multirow{3}{*}{$\begin{array}{c}\begin{array}{c}=1 \text { if } \\
\text { streng- } \\
\text { then } \mathrm{mgt}\end{array} \\
(9)\end{array}$} \\
\hline & & $\mathrm{CEO}$ & CEO & $\mathrm{CEO}$ & CEO & $\mathrm{CEO}$ & $\mathrm{CEO}$ & $\begin{array}{l}\text { junior } \\
\text { manager }\end{array}$ & \\
\hline & & $(2)$ & $(3)$ & $(4)$ & $(5)$ & (6) & $(7)$ & $(8)$ & \\
\hline \multicolumn{10}{|l|}{ Board's information set and beliefs } \\
\hline \multirow{2}{*}{$=1$ if manager viewed as incompetent in $t-1$} & $1.148^{* * *}$ & $1.336^{* * *}$ & $1.366^{* * *}$ & $1.400^{* * *}$ & $1.335^{* * *}$ & $1.020^{* * *}$ & $1.013^{* * *}$ & $0.768^{* * *}$ & $0.395^{* * *}$ \\
\hline & 0.123 & 0.130 & 0.131 & 0.282 & 0.130 & 0.179 & 0.177 & 0.129 & 0.136 \\
\hline \multirow[t]{2}{*}{$\ldots \times(=1$ if corporate governance law enacted $)$} & & & & & & $0.592^{* *}$ & $0.577^{* *}$ & & \\
\hline & & & & & & 0.248 & 0.290 & & \\
\hline \multirow[t]{2}{*}{$\ldots \mathrm{x}$ (=1 if fund has majority ownership) } & & & & & & & $1.516^{*}$ & & \\
\hline & & & & & & & 0.823 & & \\
\hline$\ldots \times \mathrm{x}(=1$ if corporate governance law enacted $)$ & & & & & & & $-1.473^{*}$ & & \\
\hline \multirow{3}{*}{$=1$ if poor performance blamed on bad luck in $t-1$} & & & & & & & 0.823 & & \\
\hline & $-0.259^{* *}$ & -0.070 & -0.069 & & -0.069 & -0.084 & -0.137 & -0.016 & $0.265^{* *}$ \\
\hline & 0.125 & 0.129 & 0.131 & & 0.129 & 0.128 & 0.128 & 0.124 & 0.131 \\
\hline \multirow{2}{*}{$\begin{array}{l}=1 \text { if poor performance blamed on manager's } \\
\text { decisions in } t-1\end{array}$} & 0.126 & 0.032 & 0.029 & & 0.003 & 0.069 & 0.122 & 0.281 & $0.487^{* *}$ \\
\hline & 0.205 & 0.179 & 0.215 & & 0.228 & 0.177 & 0.180 & 0.205 & 0.191 \\
\hline \multirow{2}{*}{$\begin{array}{l}=1 \text { if board complained about moral hazard } \\
\text { problems in } t-1\end{array}$} & & & & & 0.056 & & & & \\
\hline & & & & & 0.331 & & & & \\
\hline \multirow[t]{2}{*}{ performance in year $t-1$ relative to budget } & $-0.157^{* * *}$ & $-0.316^{* * *}$ & $-0.320^{* * *}$ & $-0.196^{* *}$ & $-0.316^{* * *}$ & $-0.445^{* * *}$ & $-0.325^{* * *}$ & $-0.128^{* * *}$ & -0.007 \\
\hline & 0.050 & 0.050 & 0.057 & 0.098 & 0.050 & 0.084 & 0.051 & 0.050 & 0.046 \\
\hline \multirow[t]{2}{*}{$\ldots x$ (=1 if corporate governance law enacted) } & & & & & & $0.206^{* *}$ & & & \\
\hline & & & & & & 0.101 & & & \\
\hline \multicolumn{10}{|l|}{ Deal characteristics } \\
\hline \multirow[t]{2}{*}{$\log$ investment cost through $t-1$} & $0.085^{* * *}$ & -0.006 & -0.007 & 0.066 & -0.006 & -0.003 & -0.003 & 0.013 & 0.028 \\
\hline & 0.033 & 0.033 & 0.029 & 0.064 & 0.033 & 0.033 & 0.032 & 0.038 & 0.039 \\
\hline \multirow[t]{2}{*}{$=1$ if privatization } & $0.342^{* *}$ & $0.392^{* *}$ & $0.402^{* *}$ & $0.441^{*}$ & $0.392^{* *}$ & $0.369^{* *}$ & $0.382^{* *}$ & 0.137 & $0.501^{* * *}$ \\
\hline & 0.134 & 0.167 & 0.175 & 0.230 & 0.167 & 0.165 & 0.170 & 0.156 & 0.171 \\
\hline \multirow[t]{2}{*}{$=1$ if deal is staged } & -0.047 & $0.172^{*}$ & $0.177^{*}$ & 0.106 & $0.172^{*}$ & $0.162^{*}$ & 0.137 & 0.097 & $0.427^{* * *}$ \\
\hline & 0.086 & 0.093 & 0.100 & 0.153 & 0.093 & 0.093 & 0.094 & 0.092 & 0.089 \\
\hline \multirow[t]{2}{*}{$=1$ if fund has majority ownership } & & & & & & & 0.028 & & \\
\hline & & & & & & & 0.181 & & \\
\hline \multirow[t]{2}{*}{$\ldots \times \mathrm{x}(=1$ if corp governance law enacted) } & & & & & & & 0.092 & & \\
\hline & & & & & & & 0.221 & & \\
\hline \multicolumn{10}{|l|}{ Reform progress and macro conditions } \\
\hline \multirow[t]{2}{*}{ lagged EBRD transition indicator } & -0.175 & 0.119 & 0.113 & -0.118 & 0.119 & 0.127 & 0.053 & -0.101 & $-0.349^{* *}$ \\
\hline & 0.174 & 0.191 & 0.266 & 0.407 & 0.191 & 0.190 & 0.178 & 0.225 & 0.150 \\
\hline \multirow[t]{2}{*}{ lagged real GDP growth } & -0.002 & -0.007 & -0.007 & -0.027 & -0.007 & -0.008 & -0.010 & 0.013 & -0.001 \\
\hline & 0.012 & 0.014 & 0.016 & 0.024 & 0.014 & 0.014 & 0.014 & 0.016 & 0.013 \\
\hline Law changes & & & & & & & & & \\
\hline$=1$ if corporate governance law enacted empowering & -0.051 & $0.644^{* * *}$ & $0.657^{* * *}$ & $0.915^{* * *}$ & $0.645^{* * *}$ & 0.027 & $0.560^{* * *}$ & 0.117 & 0.064 \\
\hline the board to fire the CEO at will & 0.134 & 0.148 & 0.153 & 0.249 & 0.148 & 0.280 & 0.150 & 0.138 & 0.136 \\
\hline Diagnostics & & & & & & & & & \\
\hline Wald test: all coeff. $=0\left(\chi^{2}\right)$ & $161.7^{* * *}$ & $283.1^{* * *}$ & $194.2^{* * *}$ & $116.0^{* * *}$ & $283.1^{* * *}$ & $237.8^{* * *}$ & $293.0^{* * *}$ & $97.1^{* * *}$ & $113.7^{* * *}$ \\
\hline Staiger-Stock (1997) test $\left(\chi^{2}\right)$ & 0.1 & $19.0^{* * *}$ & $18.6^{* * *}$ & $13.5^{* * *}$ & $19.0^{* * *}$ & n.m. & n.m. & 0.7 & 0.2 \\
\hline Pseudo $R^{2}$ (adjusted $R^{2}$ in columns 6 and 7 ) & $13.6 \%$ & $19.9 \%$ & $19.9 \%$ & $19.3 \%$ & $19.9 \%$ & $16.4 \%$ & $21.1 \%$ & $9.3 \%$ & $10.3 \%$ \\
\hline
\end{tabular}


Table 4. Instrument Validity.

This table reports four instrument validity test. The test in column 1 is based on the fact that governance reform can take two forms: It can either empower the board to fire the CEO at will or it can allow the shareholders' meeting to delegate its power to fire the CEO to the board through a charter amendment. We base identification only on the first type of reform, since law changes that require a charter amendment do not affect the distribution of power within the firm. Indeed, no sample firm amended its charter in response to the second type of reform in our sample period. Thus, such reforms should have no effect on CEO turnover. Column 2 tests whether the probability of CEO turnover jumps in the year the law was changed, rather than earlier, and then remains higher. In column 3 , we test whether it is speculation about possible governance reform or its actual enactment that affects boards' propensity to fire a CEO. To test this, we distinguish between the year governance reform was first mooted in the local press and the year it was enacted. Reform was faster in some countries than in others. The time between first press reports of reform and final enactment ranges from zero years (in Croatia) to three (in Latvia), with most countries taking one or two years. Column 4 restricts the sample to the 1,480 investments that were undertaken two or more years before the country in question adopted a governance law. All four specifications include country, industry, and year effects. Estimation uses probit; similar results, reported in the Internet Appendix, obtain using linear probability models. The number of observations is 2,103 in columns 1, 2, and 3, and 1,480 in column 4. Heteroskedasticity-consistent standard errors, clustered on portfolio firm, are reported in italics beneath the coefficient estimates. See the Internet Appendix for specifications where we cluster the standard errors on country instead. We use ${ }^{* * *},{ }^{* *}$, and ${ }^{*}$ to denote significance at the $1 \%, 5 \%$, and $10 \%$ level (two-sided), respectively.

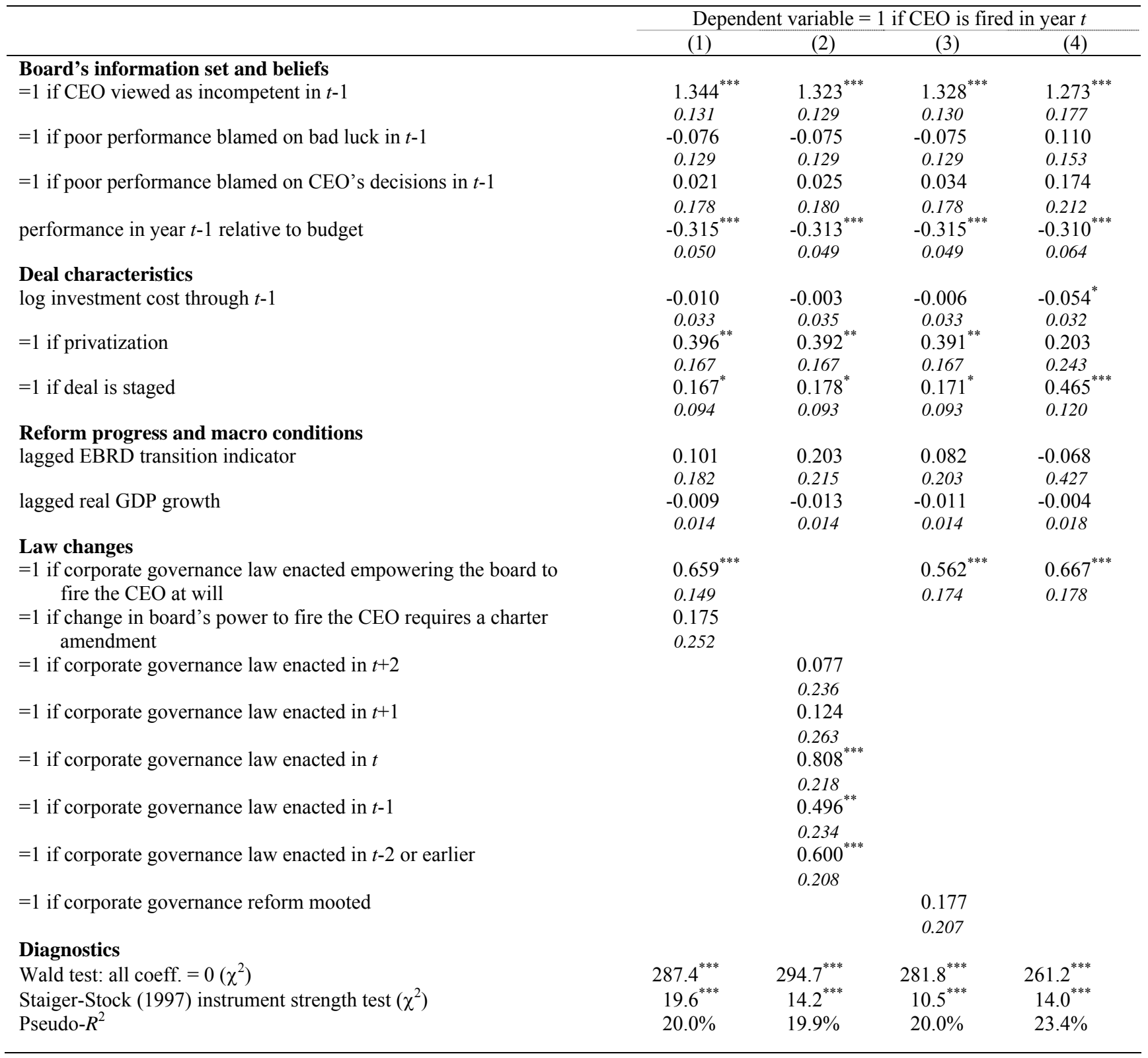


Table 5. Naïve and Reduced-form Performance Models.

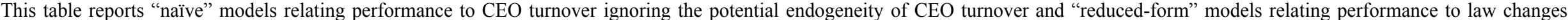

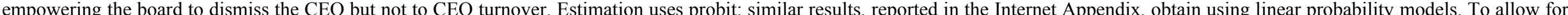

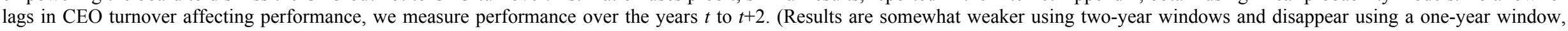

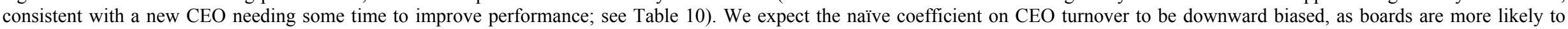

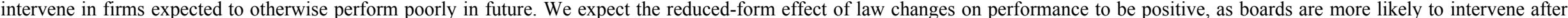

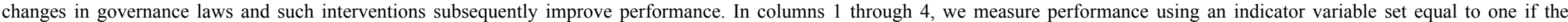

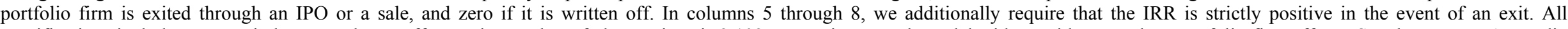

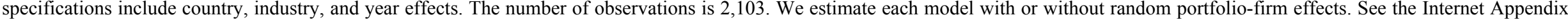

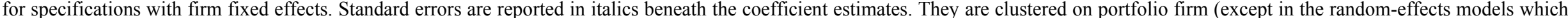

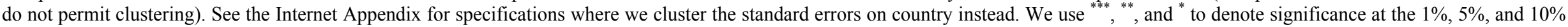
level (two-sided), respectively.

\begin{tabular}{|c|c|c|c|c|c|c|c|c|}
\hline \multirow[t]{3}{*}{ Dependent variable $=1$ if... } & \multicolumn{4}{|c|}{. exit in years $t$ to $t+2$} & \multicolumn{4}{|c|}{. exit at positive IRR in years $t$ to $t+2$} \\
\hline & \multicolumn{2}{|c|}{ Naïve models } & \multicolumn{2}{|c|}{ Reduced-form models } & \multicolumn{2}{|c|}{ Naïve models } & \multicolumn{2}{|c|}{ Reduced-form models } \\
\hline & (1) & $(2)$ & (3) & (4) & $(5)$ & $(6)$ & $(7)$ & (8) \\
\hline \multicolumn{9}{|l|}{ Board interventions } \\
\hline$=1$ if CEO dismissed in year $t$ & $\begin{array}{c}-0.198 \\
0.129\end{array}$ & $\begin{array}{r}-0.065 \\
0.163\end{array}$ & & & $\begin{array}{c}-0.333^{* *} \\
0.150\end{array}$ & $\begin{array}{r}-0.351 \\
0.222\end{array}$ & & \\
\hline \multicolumn{9}{|l|}{ Board's information set and beliefs } \\
\hline$=1$ if $\mathrm{CEO}$ viewed as incompetent in $t-1$ & $\begin{array}{r}-0.028 \\
0.152\end{array}$ & $\begin{array}{r}-0.143 \\
0.190\end{array}$ & $\begin{array}{c}-0.078 \\
0.146\end{array}$ & $\begin{array}{r}-0.194 \\
0.193\end{array}$ & $\begin{array}{l}0.038 \\
0.171\end{array}$ & $\begin{array}{l}0.265 \\
0.263\end{array}$ & $\begin{array}{r}-0.067 \\
0.163\end{array}$ & $\begin{array}{l}0.085 \\
0.254\end{array}$ \\
\hline$=1$ if poor performance blamed on bad luck in $t-1$ & -0.048 & -0.062 & -0.009 & -0.049 & 0.111 & 0.242 & 0.151 & 0.213 \\
\hline$=1$ if poor performance blamed on CEO's & $\begin{array}{l}0.103 \\
0.221\end{array}$ & 0.132 $0.552^{* *}$ & $\begin{array}{l}0.103 \\
0.193\end{array}$ & $\begin{array}{l}0.142 \\
0.467^{* *}\end{array}$ & $\begin{array}{l}0.110 \\
0.051\end{array}$ & $\begin{array}{l}0.166 \\
0.417\end{array}$ & $\begin{array}{l}0.110 \\
0.026\end{array}$ & $\begin{array}{l}0.174 \\
0.363\end{array}$ \\
\hline $\begin{array}{l}\text { decisions in } t-1 \\
\text { performance in year } t-1 \text { relative to budget }\end{array}$ & $\begin{array}{l}0.170 \\
0.133^{* * *} \\
0.042\end{array}$ & $\begin{array}{l}0.222 \\
0.112^{* *} \\
0.050\end{array}$ & $\begin{array}{l}0.170 \\
0.142^{\text {*** }} \\
0.042\end{array}$ & $\begin{array}{l}0.238 \\
0.086 \\
0.054\end{array}$ & $\begin{array}{l}0.185 \\
0.340^{* * *} \\
0.045\end{array}$ & $\begin{array}{l}0.303 \\
0.282^{* * *} \\
0.063\end{array}$ & $\begin{array}{l}0.186 \\
0.352^{* * *} \\
0.045\end{array}$ & $\begin{array}{l}0.316 \\
0.271^{* * *}\end{array}$ \\
\hline \multicolumn{9}{|l|}{ Deal characteristics } \\
\hline log investment cost through $t-1$ & $\begin{array}{l}0.058^{* *} \\
0.025\end{array}$ & $\begin{array}{l}0.194^{* * *} \\
0.047\end{array}$ & $\begin{array}{l}0.061^{* *} \\
0.026\end{array}$ & $\begin{array}{l}0.214^{* * *} \\
0.051\end{array}$ & $\begin{array}{l}0.095^{* *} \\
0.039\end{array}$ & $\begin{array}{l}0.310^{* * *} \\
0.071\end{array}$ & $\begin{array}{l}0.094^{* *} \\
0.039\end{array}$ & $0.268^{* * *}$ \\
\hline$=1$ if privatization & $\begin{array}{l}0.058 \\
0.143\end{array}$ & $\begin{array}{l}0.032 \\
0.035\end{array}$ & 0.055 & 0.035 & 0.187 & $0.092^{* *}$ & 0.177 & $0.087^{*}$ \\
\hline$=1$ if deal is staged & $\begin{array}{c}-0.389^{* * *} \\
0.083\end{array}$ & $\begin{array}{c}-0.090^{* * *} \\
0.020\end{array}$ & $\begin{array}{l}-0.100 \\
0.087\end{array}$ & $\begin{array}{c}-0.038 \\
0.098^{* * *} \\
0.023\end{array}$ & $\begin{array}{c}0.181 \\
-0.288^{* * *} \\
0.097\end{array}$ & $\begin{array}{c}-0.093^{\text {*** }} \\
0.028\end{array}$ & $\begin{array}{c}0.190 \\
0.100\end{array}$ & $\begin{array}{c}-0.040 \\
0.096^{* * *} \\
0.028\end{array}$ \\
\hline \multicolumn{9}{|l|}{ Reform progress and macro conditions } \\
\hline lagged EBRD transition indicator & $\begin{array}{l}0.597^{* * *} \\
0.178\end{array}$ & $\begin{array}{l}0.354^{* * *} \\
0.023\end{array}$ & $\begin{array}{l}0.314^{*} \\
0.189\end{array}$ & $\begin{array}{l}0.306^{* * *} \\
0.027\end{array}$ & $\begin{array}{l}0.267 \\
0.182\end{array}$ & $\begin{array}{l}0.375^{\text {*** }} \\
0.029\end{array}$ & $\begin{array}{l}0.093 \\
0.199\end{array}$ & $\begin{array}{l}0.301^{* * *} \\
0.032\end{array}$ \\
\hline lagged real GDP growth & $\begin{array}{l}0.054^{* * *} \\
0.012\end{array}$ & $\begin{array}{l}0.128^{* * *} \\
0.016\end{array}$ & $\begin{array}{l}0.065^{* * *} \\
0.013\end{array}$ & $\begin{array}{l}0.172^{* * *} \\
0.019\end{array}$ & $\begin{array}{l}0.057^{* * *} \\
0.014\end{array}$ & $\begin{array}{l}0.159^{* * *} \\
0.021\end{array}$ & $\begin{array}{l}0.067^{* * *} \\
0.015\end{array}$ & $\begin{array}{l}0.197^{* * *} \\
0.023\end{array}$ \\
\hline \multicolumn{9}{|l|}{ Instrument } \\
\hline$=1$ if corporate governance law enacted empowering & & & $0.696^{* * *}$ & $1.762^{* * *}$ & & & $0.462^{* * *}$ & $1.586^{* * *}$ \\
\hline the board to fire the $\mathrm{CEO}$ at will & & & 0.136 & 0.187 & & & 0.149 & 0.215 \\
\hline \multicolumn{9}{|l|}{ Diagnostics } \\
\hline Portfolio-firm effects? & No & Yes & No & Yes & No & Yes & No & Yes \\
\hline Wald test: all coeff. $=0\left(\chi^{2}\right)$ & $185.1^{* * *}$ & $317.6^{* * * *}$ & $200.0^{* * *}$ & $390.2^{* * *}$ & $283.7^{* * *}$ & $288.3^{* * *}$ & $265.8^{* * *}$ & $329.5^{* * *}$ \\
\hline Likelihood ratio test: portfolio-firm effects $=0\left(\chi^{2}\right)$ & n.a. & $290.4^{* * *}$ & n.a. & $367.1^{* * *}$ & n.a. & $378.6^{* * *}$ & n.a. & $427.7^{* * *}$ \\
\hline Pseudo- $R^{2}$ & $9.3 \%$ & $19.5 \%$ & $11.6 \%$ & $24.5 \%$ & $15.3 \%$ & $30.1 \%$ & $16.2 \%$ & $32.9 \%$ \\
\hline
\end{tabular}


Table 6. Structural Performance Models Using Law Changes as an Instrument.

In columns 1-3, we measure performance using an indicator variable set equal to one if the portfolio firm is exited through an IPO or a sale, and zero otherwise. In columns 4-6, we additionally require that the IRR be strictly positive in the event of an exit. Given the binary nature of the dependent variable (exit) and of the potentially endogenous variable (CEO turnover), models 1-2 and 4-5 are estimated using a seemingly unrelated bivariate probit model that treats CEO turnover as endogenous. Specifically, the performance equation shown here is jointly estimated with the CEO turnover model shown in column 2, Table 3 . Columns 1 and 4 are estimated without portfolio-firm effects while columns 2 and 5 include random portfolio-firm effects to control for firm-level omitted variables which are allowed to be correlated across the CEO turnover and performance equations. All four probit specifications include country, industry, and year effects. In columns 3 and 6, we estimate linear probability models using 2SLS with portfolio-firm fixed effects. Inclusion of firm fixed effects implies that time-invariant regressors (such as country and industry effects, the staging variable, and the privatization indicator) must be dropped from these two models. The exogeneity test reported for the probit models is a likelihood ratio test of the null that the disturbances in the CEO turnover and performance equations are uncorrelated. Based on Monte Carlo evidence, Monfardini and Radice (2008) conclude that this test performs well even when the distribution of the errors is misspecified, unlike a simple $t$-test on the correlation coefficient. The Staiger-Stock test is a Wald test of the null hypothesis that the instrument does not correlate with board interventions. It has a critical value of 10 . Standard errors are reported in italics beneath the coefficient estimates. They are clustered on portfolio firm (except in the random-effects models which do not permit clustering). See the Internet Appendix for specifications where we cluster the standard errors on country instead. We use ${ }^{* * *},{ }^{* *}$, and ${ }^{*}$ to denote significance at the $1 \%, 5 \%$, and $10 \%$ level (two-sided), respectively. The number of observations is 2,103 .

\begin{tabular}{|c|c|c|c|c|c|c|}
\hline & \multicolumn{6}{|c|}{ Dependent variable $=1$ if $\ldots$} \\
\hline & \multicolumn{3}{|c|}{$\ldots$ exit in years $t$ to $t+2$} & \multicolumn{3}{|c|}{... exit at positive IRR in $t$ to $t+2$} \\
\hline & \multicolumn{2}{|c|}{ Bivariate probit } & \multirow{2}{*}{$\begin{array}{c}\text { 2SLS } \\
(3)\end{array}$} & \multicolumn{2}{|c|}{ Bivariate probit } & \multirow{2}{*}{$\begin{array}{c}\text { 2SLS } \\
(6)\end{array}$} \\
\hline & $(1)$ & $(2)$ & & $(4)$ & $(5)$ & \\
\hline \multicolumn{7}{|l|}{ Board interventions } \\
\hline \multirow[t]{2}{*}{$=1$ if CEO dismissed in year $t$} & $1.232^{* * *}$ & $1.805^{* * *}$ & $1.329^{* *}$ & $1.256^{* * *}$ & $1.396^{* * *}$ & $0.747^{* *}$ \\
\hline & 0.388 & 0.171 & 0.582 & 0.409 & 0.329 & 0.341 \\
\hline \multicolumn{7}{|l|}{ Board's information set and beliefs } \\
\hline \multirow[t]{2}{*}{$=1$ if $\mathrm{CEO}$ viewed as incompetent in $t-1$} & $-0.492^{* *}$ & $-0.868^{* * *}$ & $-0.587^{* *}$ & $-0.429^{*}$ & $-0.488^{*}$ & $-0.286^{* *}$ \\
\hline & 0.223 & 0.169 & 0.233 & 0.230 & 0.296 & 0.140 \\
\hline \multirow[t]{2}{*}{$=1$ if poor perf. blamed on bad luck in $t-1$} & -0.001 & 0.003 & -0.036 & 0.146 & 0.038 & 0.034 \\
\hline & 0.098 & 0.119 & 0.039 & 0.106 & 0.163 & 0.029 \\
\hline \multirow{4}{*}{$\begin{array}{l}=1 \text { if poor performance blamed on CEO's } \\
\text { decisions in } t-1 \\
\text { performance in year } t-1 \text { relative to budget }\end{array}$} & 0.216 & 0.061 & 0.010 & 0.047 & 0.065 & -0.013 \\
\hline & 0.157 & 0.222 & 0.062 & 0.179 & 0.313 & 0.048 \\
\hline & $0.178^{* * *}$ & $0.153^{* * *}$ & $0.056^{* *}$ & $0.368^{* * *}$ & $0.292^{* * *}$ & $0.060^{* * *}$ \\
\hline & 0.041 & 0.042 & 0.023 & 0.044 & 0.056 & 0.015 \\
\hline \multicolumn{7}{|l|}{ Deal characteristics } \\
\hline \multirow[t]{2}{*}{ log investment cost through $t-1$} & $0.061^{* *}$ & $0.323^{* * *}$ & -0.012 & $0.101^{* *}$ & $0.651^{* * *}$ & -0.007 \\
\hline & 0.025 & 0.036 & 0.008 & 0.040 & 0.053 & 0.006 \\
\hline \multirow[t]{2}{*}{$=1$ if privatization } & -0.022 & 0.007 & & 0.105 & $0.153^{* * *}$ & \\
\hline & 0.146 & 0.016 & & 0.177 & 0.021 & \\
\hline \multirow[t]{2}{*}{$=1$ if deal is staged } & $-0.378^{* * *}$ & $-0.139^{* * *}$ & & $-0.278^{* * *}$ & $-0.136^{* * *}$ & \\
\hline & 0.082 & 0.010 & & 0.095 & 0.013 & \\
\hline \multicolumn{7}{|l|}{ Reform progress and macro conditions } \\
\hline lagged EBRD transition indicator & $0.648^{* * *}$ & $0.639^{* * *}$ & $0.286^{* *}$ & $0.316^{*}$ & $0.807^{* * *}$ & $0.200^{* *}$ \\
\hline \multirow{3}{*}{ lagged real GDP growth } & 0.185 & 0.028 & 0.127 & 0.186 & 0.040 & 0.096 \\
\hline & $0.061^{* * *}$ & $0.167^{* * *}$ & $0.010^{* * *}$ & $0.063^{* * *}$ & $0.217^{* * *}$ & $0.010^{* * *}$ \\
\hline & 0.012 & 0.014 & 0.004 & 0.014 & 0.018 & 0.003 \\
\hline \multicolumn{7}{|l|}{ Diagnostics } \\
\hline Portfolio-firm effects? & No & Random & Fixed & No & Random & Fixed \\
\hline Wald test: all coeff. $=0\left(\chi^{2}\right)$ & $865.1^{* * *}$ & $1,102.7^{* *}$ & $496.4^{* * *}$ & $917.1^{* * *}$ & $819.5^{* * *}$ & $545.2^{* * *}$ \\
\hline Exogeneity test (LR test) $\left(\chi^{2}\right)$ & $11.0^{* * *}$ & $351.9^{* * *}$ & n.m. & $9.5^{* * *}$ & $441.1^{* * *}$ & n.m. \\
\hline Staiger-Stock test $\left(\chi^{2}\right)$ & $26.3^{* * *}$ & $16.2^{* * *}$ & $13.6^{* * *}$ & $16.5^{* * *}$ & $12.5^{* * *}$ & $16.6^{* * *}$ \\
\hline Pseudo- $R^{2}$; within-groups $R^{2}$ in cols. 3,6 & $13.5 \%$ & $22.0 \%$ & $45.9 \%$ & $17.7 \%$ & $29.3 \%$ & $32.0 \%$ \\
\hline
\end{tabular}


Table 7. Effect of Board Intervention on Performance Relative to Budget.

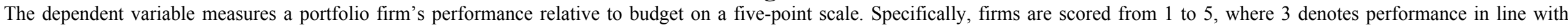

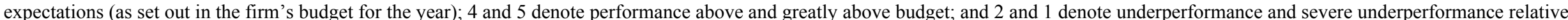

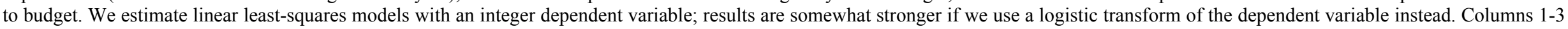

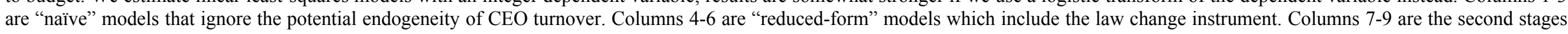

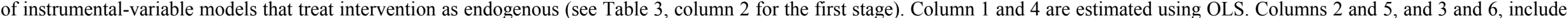

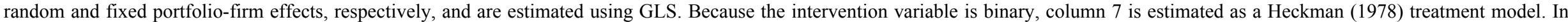

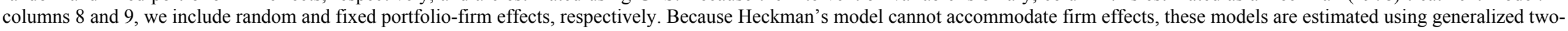

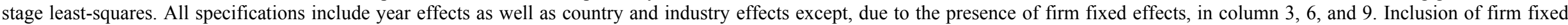

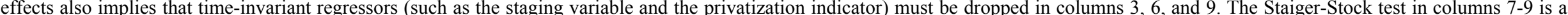

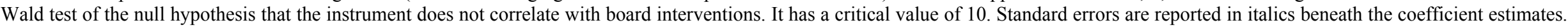

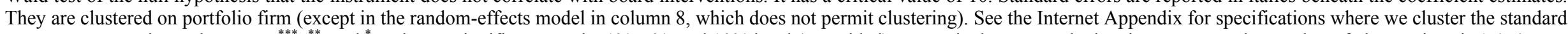

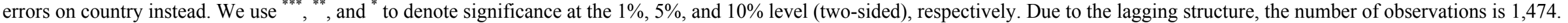

\begin{tabular}{|c|c|c|c|c|c|c|c|c|c|}
\hline & \multicolumn{9}{|c|}{ Dependent variable: Performance in year $t+1$ relative to budget } \\
\hline & \multicolumn{3}{|c|}{ Naïve models } & \multicolumn{3}{|c|}{ Reduced-form models } & \multicolumn{3}{|c|}{ IV models } \\
\hline & $(1)$ & $(2)$ & $(3)$ & $(4)$ & $(5)$ & $(6)$ & (7) & $(8)$ & (9) \\
\hline \multicolumn{10}{|l|}{ Board interventions } \\
\hline \multirow{2}{*}{$=1$ if CEO dismissed in year $t$} & $0.183^{*}$ & $0.225^{* *}$ & $0.342^{* * *}$ & & & & $1.579^{* * *}$ & $1.944^{* *}$ & $2.168^{*}$ \\
\hline & 0.098 & 0.095 & 0.099 & & & & 0.243 & 0.935 & 1.267 \\
\hline \multicolumn{10}{|l|}{ Board's information set and beliefs } \\
\hline \multirow[t]{2}{*}{$=1$ if CEO viewed as incompetent in $t-1$} & $-0.226^{*}$ & -0.150 & -0.052 & -0.154 & -0.057 & 0.102 & $-0.743^{* * *}$ & $-0.865^{* *}$ & -0.850 \\
\hline & 0.119 & 0.115 & 0.121 & 0.112 & 0.106 & 0.106 & 0.150 & 0.375 & 0.572 \\
\hline \multirow[t]{2}{*}{$=1$ if poor perf. blamed on bad luck in $t-1$} & $0.290^{* * *}$ & $0.261^{* * *}$ & $0.206^{* *}$ & $0.277^{* * *}$ & $0.246^{* * *}$ & $0.180^{* *}$ & $0.333^{* * *}$ & $0.337^{* * *}$ & $0.301^{* *}$ \\
\hline & 0.092 & 0.090 & 0.091 & 0.092 & 0.090 & 0.091 & 0.100 & 0.095 & 0.118 \\
\hline \multirow{2}{*}{$\begin{array}{l}=1 \text { if poor performance blamed on CEO's decisions } \\
\text { in } t-1\end{array}$} & 0.170 & 0.253 & $0.322^{*}$ & 0.163 & 0.239 & $0.308^{*}$ & 0.119 & 0.136 & 0.246 \\
\hline & 0.178 & 0.173 & 0.172 & 0.175 & 0.170 & 0.170 & 0.175 & 0.161 & 0.194 \\
\hline \multirow[t]{2}{*}{ performance in year $t-1$ relative to budget } & $0.310^{* * *}$ & $0.144^{* * *}$ & $-0.098^{* * *}$ & $0.298^{* * *}$ & $0.132^{* * *}$ & $-0.115^{* * *}$ & $0.382^{* * *}$ & $0.346^{* * *}$ & -0.023 \\
\hline & 0.038 & 0.036 & 0.037 & 0.037 & 0.035 & 0.036 & 0.041 & 0.058 & 0.072 \\
\hline \multicolumn{10}{|l|}{ Deal characteristics } \\
\hline \multirow[t]{2}{*}{ log investment cost through $t-1$} & $0.033^{* *}$ & $0.023^{*}$ & 0.004 & $0.032^{* *}$ & $0.022^{*}$ & 0.005 & $0.032^{* *}$ & $0.029^{*}$ & -0.002 \\
\hline & 0.014 & 0.012 & 0.013 & 0.014 & 0.012 & 0.013 & 0.014 & 0.017 & 0.016 \\
\hline \multirow[t]{2}{*}{$=1$ if privatization } & $0.212^{*}$ & $0.256^{*}$ & & $0.224^{*}$ & $0.274^{*}$ & & 0.154 & 0.153 & \\
\hline & 0.125 & 0.148 & & 0.123 & 0.145 & & 0.147 & 0.138 & \\
\hline \multirow[t]{2}{*}{$=1$ if deal is staged } & -0.070 & -0.070 & & -0.067 & -0.068 & & -0.095 & -0.100 & \\
\hline & 0.065 & 0.080 & & 0.064 & 0.079 & & 0.069 & 0.072 & \\
\hline \multicolumn{10}{|l|}{ Reform progress and macro conditions } \\
\hline \multirow[t]{2}{*}{ lagged EBRD transition indicator } & -0.165 & -0.188 & $-0.458^{*}$ & $-0.249^{* *}$ & $-0.296^{* *}$ & $-0.679^{* *}$ & $-0.230^{* *}$ & $-0.246^{*}$ & $-0.450^{*}$ \\
\hline & 0.103 & 0.128 & 0.264 & 0.111 & 0.136 & 0.274 & 0.101 & 0.137 & 0.268 \\
\hline \multirow[t]{2}{*}{ lagged real GDP growth } & 0.007 & 0.006 & 0.002 & 0.008 & 0.007 & 0.004 & 0.011 & 0.012 & 0.010 \\
\hline & 0.009 & 0.009 & 0.009 & 0.009 & 0.009 & 0.009 & 0.009 & 0.009 & 0.010 \\
\hline \multicolumn{10}{|l|}{ Instrument } \\
\hline \multirow{2}{*}{$\begin{array}{l}=1 \text { if corporate governance law enacted empowering } \\
\text { the board to fire the CEO at will }\end{array}$} & & & & $0.181^{*}$ & $0.203^{*}$ & $0.255^{*}$ & & & \\
\hline & & & & 0.101 & 0.112 & 0.141 & & & \\
\hline \multicolumn{10}{|l|}{ Diagnostics } \\
\hline Portfolio-firm effects? & No & Random & Fixed & No & Random & Fixed & No & Random & Fixed \\
\hline Wald test: all coeff. $=0\left(\chi^{2}\right)$ & $328.8^{* * *}$ & $200.6^{* * *}$ & $60.2^{* * *}$ & $338.5^{* *}$ & $202.5^{* * *}$ & $50.5^{* * * *}$ & $330.8^{* * *}$ & $191.4^{* * *}$ & $42.2^{* * * *}$ \\
\hline Wald test: independent equations & 16.9 & n.a. & n.a. & n.a. & n.a. & n.a. & $26.8^{* * *}$ & n.a. & n.a. \\
\hline Staiger-Stock test $\left(\chi^{2} ; F\right.$ in cols $\left.3,6,9\right)$ & n.a. & n.a. & n.a. & n.a. & n.a. & n.a. & $28.0^{* * *}$ & $19.1^{* * *}$ & $10.9^{* * *}$ \\
\hline$R^{2}$ & $15.0 \%$ & $14.3 \%$ & $5.1 \%$ & $16.9 \%$ & $14.4 \%$ & $5.1 \%$ & $10.7 \%$ & $8.5 \%$ & $4.5 \%$ \\
\hline
\end{tabular}


Table 8. Addressing Identification Concerns.

This table explores two challenges to our identification strategy: Corporate governance law changes might correlate with an omitted variable, e.g. contemporaneous improvements in local business conditions, rather than capturing changes in board power; and managers might raise their game in response to an increase in the threat of dismissal causing the exclusion restriction to fail. We report two tests of the first story. The first test restricts the sample to the three countries that strengthened the power of the board relative to the CEO through an amendment to a commercial law enacted some years earlier (i.e., Croatia, Romania, and Russia; see Table 2), using the same reduced-form specification as in Table 5. Note that each of these countries replaced its Soviet-era corporate law with Western-style corporate law before sample funds made any investments. Thus, there is no need to include separate indicators for commercial law reform and subsequent corporate governance amendments; the instrument isolates the effect of changes in corporate governance law on performance. The second test interacts law changes with an indicator variable for majority-owned portfolio firms. If law changes simply proxy for contemporaneous improvements in the local business environment, portfolio firms should benefit regardless of the fund's ownership position. But if law changes strengthen board power, as we argue, then they should affect performance only if the fund lacks majority control. These two tests are reported in columns 1, 2, 5, and 6 . To test the second story, we run a horse race between actual law changes empowering the board to dismiss the CEO and the date when such changes were first mooted in the local press. See columns 3 and 7 . We also run a reality check on our identification strategy, testing whether - contrary to expectations - governance reforms that require a corporate charter amendment affect firm performance. See columns 4 and 8. All specifications include country, industry, and year effects. Estimation uses probit; similar results, reported in the Internet Appendix, obtain using linear probability models. The number of observations is 2,103 except in columns 1 and 5 where it is 556. Heteroskedasticity-consistent standard errors, clustered on portfolio firm, are reported in italics beneath the coefficient estimates. See the Internet Appendix for specifications where we cluster the standard errors on country instead. We use ${ }^{* * *},{ }^{* *}$, and ${ }^{*}$ to denote significance at the $1 \%, 5 \%$, and $10 \%$ level (two-sided), respectively.

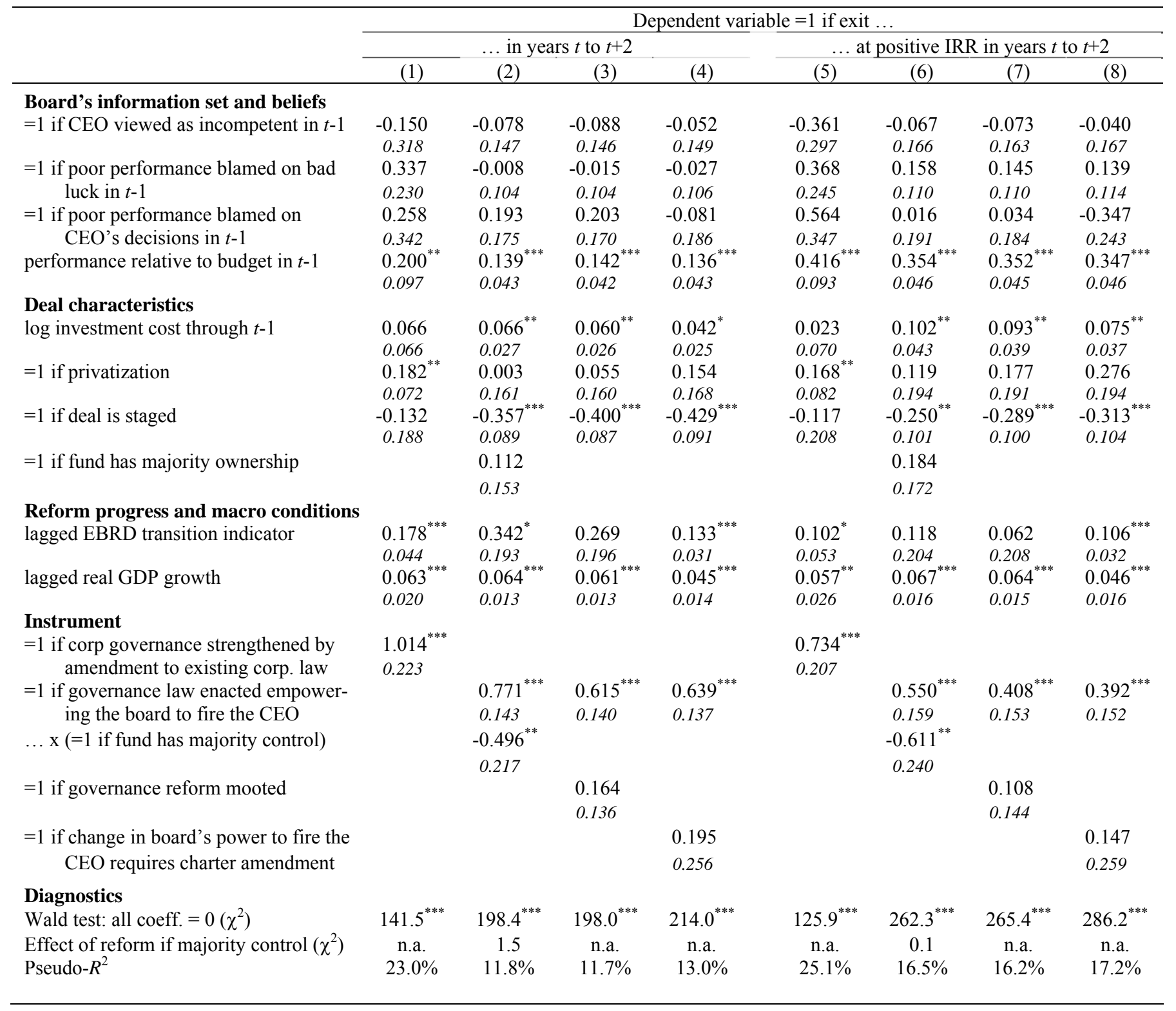


Table 9. Testing for Selection Effects.

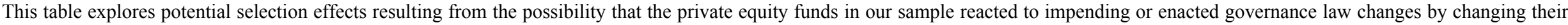

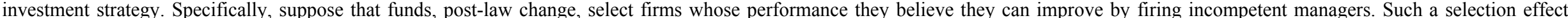

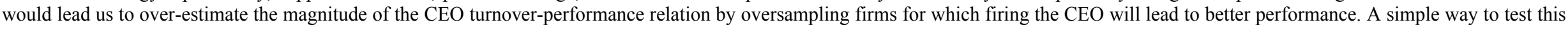

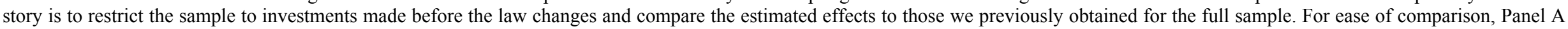

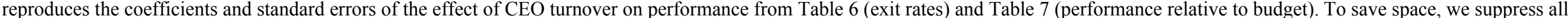

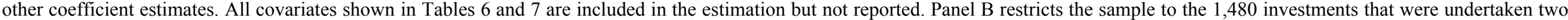

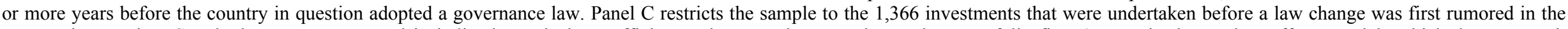

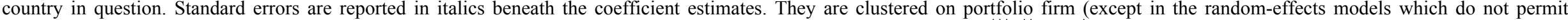

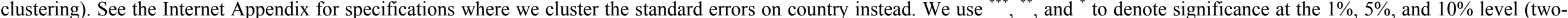
sided), respectively.

\begin{tabular}{|c|c|c|c|c|c|c|c|c|c|}
\hline & \multicolumn{6}{|c|}{ Dependent variable $=1$ if } & \multirow{3}{*}{\multicolumn{3}{|c|}{$\begin{array}{c}\text { Dep. variable: Performance in yea } \\
t+1 \text { rel. to budget } \\
\text { Instrumental variables model }\end{array}$}} \\
\hline & \multicolumn{3}{|c|}{$\ldots$ exit in years $t$ to $t+2$} & \multicolumn{3}{|c|}{$\ldots$ exit at positive IRR in $t$ to $t+2$} & & & \\
\hline & \multicolumn{2}{|c|}{ Bivariate probit } & \multirow{2}{*}{$\begin{array}{c}\text { 2SLS } \\
\mathrm{w} / \mathrm{FE} \\
(3)\end{array}$} & \multicolumn{2}{|c|}{ Bivariate probit } & \multirow{2}{*}{$\begin{array}{c}\text { 2SLS } \\
\text { w/ FE } \\
(6)\end{array}$} & & & \\
\hline & $\begin{array}{c}\text { w/o RE } \\
(1)\end{array}$ & $\begin{array}{c}\mathrm{w} / \mathrm{RE} \\
(2)\end{array}$ & & $\begin{array}{c}\text { w/o RE } \\
(4)\end{array}$ & $\begin{array}{c}\mathrm{w} / \mathrm{RE} \\
(5)\end{array}$ & & $\begin{array}{c}\text { w/o FE } \\
(7)\end{array}$ & $\begin{array}{c}\text { w/ RE } \\
(8)\end{array}$ & $\begin{array}{c}\mathrm{w} / \mathrm{FE} \\
(9)\end{array}$ \\
\hline \multicolumn{10}{|l|}{ Panel A: Baseline models (reproduced from Tables 6 and 7) } \\
\hline$=1$ if CEO dismissed in year $t$ & $\begin{array}{l}1.232^{* * *} \\
0.388\end{array}$ & $\begin{array}{l}1.805^{* * *} \\
0.171\end{array}$ & $\begin{array}{l}1.329^{* *} \\
0.582\end{array}$ & $\begin{array}{l}1.256^{* * *} \\
0.409\end{array}$ & $\begin{array}{l}1.396^{* * *} \\
0.329\end{array}$ & $\begin{array}{l}0.747^{* *} \\
0.341\end{array}$ & $\begin{array}{l}1.579^{* * *} \\
0.243\end{array}$ & $\begin{array}{l}1.944^{* *} \\
0.935\end{array}$ & $\begin{array}{l}2.168^{*} \\
1.267\end{array}$ \\
\hline $\begin{array}{l}\text { Staiger-Stock test } \\
R^{2} \text { (pseudo } R^{2} \text { in cols. } 1,2,4,5 \text {; within } R^{2} \text { in cols. } 3,6,9 \text { ) }\end{array}$ & $\begin{array}{l}26.3^{* * *} \\
13.5 \%\end{array}$ & $\begin{array}{l}16.2^{* * *} \\
22.0 \%\end{array}$ & $\begin{array}{l}13.6^{* * *} \\
45.9 \%\end{array}$ & $\begin{array}{l}16.5^{* * *} \\
17.7 \%\end{array}$ & $\begin{array}{l}12.5^{* * *} \\
29.3 \%\end{array}$ & $\begin{array}{l}16.6^{* * *} \\
32.0 \%\end{array}$ & $\begin{array}{l}28.0^{* * *} \\
10.7 \%\end{array}$ & $\begin{array}{c}19.1^{* * *} \\
8.5 \%\end{array}$ & $\begin{array}{c}10.9^{* * *} \\
4.5 \%\end{array}$ \\
\hline \multicolumn{10}{|c|}{ Panel B: Investments made 2 or more years before law change } \\
\hline$=1$ if CEO dismissed in year $t$ & $\begin{array}{l}1.130^{* * *} \\
0.409\end{array}$ & $\begin{array}{l}1.785^{* * *} \\
0.206\end{array}$ & $\begin{array}{l}1.233^{*} \\
0.644\end{array}$ & $\begin{array}{l}1.267^{* *} \\
0.499\end{array}$ & $\begin{array}{l}1.497^{* * *} \\
0.445\end{array}$ & $\begin{array}{l}0.700^{*} \\
0.394\end{array}$ & $\begin{array}{l}1.509^{* * *} \\
0.368\end{array}$ & $\begin{array}{l}2.284^{* *} \\
1.026\end{array}$ & $\begin{array}{l}2.076^{* *} \\
1.019\end{array}$ \\
\hline $\begin{array}{l}\text { Staiger-Stock test } \\
\left.R^{2} \text { (pseudo } R^{2} \text { in cols. } 1,2,4,5 \text {; within } R^{2} \text { in cols. } 3,6,9\right)\end{array}$ & $\begin{array}{l}29.0^{* * *} \\
16.8 \%\end{array}$ & $\begin{array}{l}18.2^{* * *} \\
24.4 \%\end{array}$ & $\begin{array}{l}11.0^{* * *} \\
47.4 \%\end{array}$ & $\begin{array}{l}20.2^{* * *} \\
20.2 \%\end{array}$ & $\begin{array}{l}11.9^{* * *} \\
30.2 \%\end{array}$ & $\begin{array}{l}14.2^{* * *} \\
32.5 \%\end{array}$ & $\begin{array}{l}21.6^{* * *} \\
12.6 \%\end{array}$ & $\begin{array}{c}15.4^{* * *} \\
6.3 \%\end{array}$ & $\begin{array}{c}12.8^{* * *} \\
4.5 \%\end{array}$ \\
\hline \multicolumn{10}{|l|}{ Panel C: Investments made before law change first rumored } \\
\hline$=1$ if CEO dismissed in year $t$ & $\begin{array}{l}0.996^{* *} \\
0.422\end{array}$ & $\begin{array}{l}1.735^{* * *} \\
0.230\end{array}$ & $\begin{array}{l}1.269^{* *} \\
0.646\end{array}$ & $\begin{array}{l}1.115^{*} \\
0.606\end{array}$ & $\begin{array}{l}2.013^{* * *} \\
0.207\end{array}$ & $\begin{array}{l}0.704^{*} \\
0.368\end{array}$ & $\begin{array}{l}1.187^{* *} \\
0.522\end{array}$ & $\begin{array}{l}2.317^{* *} \\
0.957\end{array}$ & $\begin{array}{l}2.252^{*} \\
1.281\end{array}$ \\
\hline $\begin{array}{l}\text { Staiger-Stock test } \\
\left.R^{2} \text { (pseudo } R^{2} \text { in cols. } 1,2,4,5 \text {; within } R^{2} \text { in cols. } 3,6,9\right)\end{array}$ & $\begin{array}{l}25.9^{* * *} \\
17.2 \%\end{array}$ & $\begin{array}{l}17.0^{* * *} \\
24.9 \%\end{array}$ & $\begin{array}{l}11.2^{* * *} \\
47.3 \%\end{array}$ & $\begin{array}{l}20.8^{* * *} \\
20.4 \%\end{array}$ & $\begin{array}{l}14.0^{* * *} \\
30.7 \%\end{array}$ & $\begin{array}{l}15.3^{* * *} \\
31.9 \%\end{array}$ & $\begin{array}{l}23.2^{* * *} \\
13.4 \%\end{array}$ & $\begin{array}{c}18.2^{* * *} \\
5.3 \%\end{array}$ & $\begin{array}{c}11.6^{* * *} \\
5.5 \%\end{array}$ \\
\hline
\end{tabular}


Table 10. Robustness Tests.

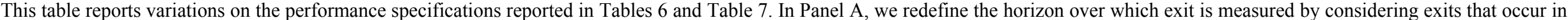

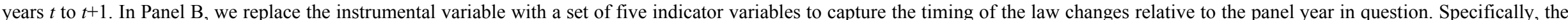

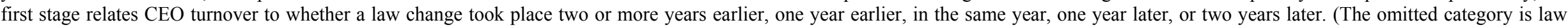

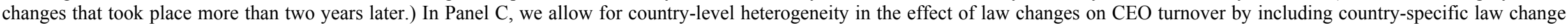

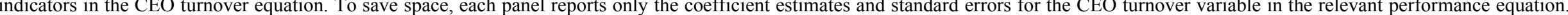

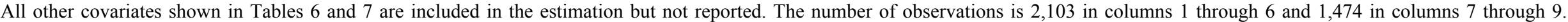

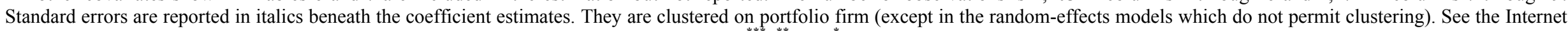
Appendix for specifications where we cluster the standard errors on country instead. We use ${ }^{* * * * *},{ }^{* *}$, and ${ }^{*}$ to denote significance at the $1 \%$, $5 \%$, and $10 \%$ level (two-sided), respectively.

\begin{tabular}{|c|c|c|c|c|c|c|c|c|c|}
\hline & \multicolumn{6}{|c|}{ Dependent variable $=1$ if $\ldots$} & \multirow{3}{*}{\multicolumn{3}{|c|}{$\begin{array}{c}\text { Dep. variable: Performance in yea } \\
t+1 \text { rel. to budget } \\
\text { Instrumental variables model }\end{array}$}} \\
\hline & \multicolumn{3}{|c|}{$\ldots$ exit in years $t$ to $t+2$} & \multicolumn{3}{|c|}{$\ldots$ exit at positive IRR in $t$ to $t+2$} & & & \\
\hline & \multicolumn{2}{|c|}{ Bivariate probit } & \multirow{2}{*}{$\begin{array}{c}\text { 2SLS } \\
\text { w/ FE } \\
(3)\end{array}$} & \multicolumn{2}{|c|}{ Bivariate probit } & \multirow{2}{*}{$\begin{array}{c}\text { 2SLS } \\
\text { w/ FE } \\
(6)\end{array}$} & & & \\
\hline & $\begin{array}{c}\text { w/o RE } \\
(1)\end{array}$ & $\begin{array}{c}\mathrm{w} / \mathrm{RE} \\
(2)\end{array}$ & & $\begin{array}{c}\text { w/o RE } \\
(4)\end{array}$ & $\begin{array}{c}\text { w/ RE } \\
(5)\end{array}$ & & $\begin{array}{c}\text { w/o FE } \\
(7)\end{array}$ & $\begin{array}{c}\mathrm{w} / \mathrm{RE} \\
(8)\end{array}$ & $\begin{array}{c}\mathrm{w} / \mathrm{FE} \\
(9)\end{array}$ \\
\hline \multicolumn{10}{|l|}{ Panel A: Alternative exit horizon (exit in year $t$ or $t+1$ ) } \\
\hline$=1$ if CEO dismissed in year $t$ & $\begin{array}{l}0.798^{* *} \\
0.386\end{array}$ & $\begin{array}{l}1.192^{* * *} \\
0.280\end{array}$ & $\begin{array}{l}0.658^{*} \\
0.374\end{array}$ & $\begin{array}{l}1.494^{* * *} \\
0.421\end{array}$ & $\begin{array}{l}1.690^{* * *} \\
0.155\end{array}$ & $\begin{array}{l}0.226 \\
0.307\end{array}$ & n.a. & n.a. & n.a. \\
\hline $\begin{array}{l}\text { Staiger-Stock test } \\
\left.R^{2} \text { (pseudo } R^{2} \text { in cols. } 1,2,4,5 \text {; within } R^{2} \text { in cols. } 3,6,9\right)\end{array}$ & $\begin{array}{l}19.6^{* * *} \\
12.4 \%\end{array}$ & $\begin{array}{l}14.8^{* * *} \\
13.5 \%\end{array}$ & $\begin{array}{l}16.6^{* * *} \\
37.4 \%\end{array}$ & $\begin{array}{l}14.3^{* * *} \\
16.2 \%\end{array}$ & $\begin{array}{l}12.9^{* * *} \\
19.4 \%\end{array}$ & $\begin{array}{l}16.6^{* * *} \\
26.5 \%\end{array}$ & & & \\
\hline \multicolumn{10}{|l|}{ Panel B: Time-varying law changes } \\
\hline$=1$ if CEO dismissed in year $t$ & $\begin{array}{l}1.392^{* * *} \\
0.403\end{array}$ & $\begin{array}{l}1.822^{* * *} \\
0.160\end{array}$ & $\begin{array}{l}1.434^{* * *} \\
0.542\end{array}$ & $\begin{array}{l}1.305^{* * *} \\
0.401\end{array}$ & $\begin{array}{l}1.345^{* * *} \\
0.366\end{array}$ & $\begin{array}{l}0.925^{*} \\
0.499\end{array}$ & $\begin{array}{l}1.586^{* * *} \\
0.222\end{array}$ & $\begin{array}{l}1.784^{* *} \\
0.915\end{array}$ & $\begin{array}{l}2.059^{* *} \\
1.042\end{array}$ \\
\hline $\begin{array}{l}\text { Staiger-Stock test } \\
R^{2} \text { (pseudo } R^{2} \text { in cols. } 1,2,4,5 \text {; within } R^{2} \text { in cols. } 3,6,9 \text { ) }\end{array}$ & $\begin{array}{l}21.6^{* * *} \\
13.5 \%\end{array}$ & $\begin{array}{l}23.7^{* * *} \\
22.2 \%\end{array}$ & $\begin{array}{l}22.5^{* * *} \\
46.1 \%\end{array}$ & $\begin{array}{l}12.7^{* * *} \\
17.7 \%\end{array}$ & $\begin{array}{l}13.8^{* * *} \\
28.2 \%\end{array}$ & $\begin{array}{l}22.5^{* * *} \\
32.2 \%\end{array}$ & $\begin{array}{l}19.6^{* * *} \\
10.7 \%\end{array}$ & $\begin{array}{c}19.1^{* * *} \\
9.1 \%\end{array}$ & $\begin{array}{l}7.1^{* * *} \\
4.7 \%\end{array}$ \\
\hline \multicolumn{10}{|l|}{ Panel C: Heterogeneous country effects } \\
\hline$=1$ if CEO dismissed in year $t$ & $\begin{array}{l}1.223^{* * *} \\
0.412\end{array}$ & $\begin{array}{l}1.732^{* * *} \\
0.189\end{array}$ & $\begin{array}{l}1.224^{* *} \\
0.562\end{array}$ & $\begin{array}{l}1.258^{* * *} \\
0.434\end{array}$ & $\begin{array}{l}1.372^{* * *} \\
0.328\end{array}$ & $\begin{array}{l}0.674^{* *} \\
0.322\end{array}$ & $\begin{array}{l}1.571^{* * *} \\
0.250\end{array}$ & $\begin{array}{l}1.971^{* *} \\
0.858\end{array}$ & $\begin{array}{l}1.888^{* *} \\
0.855\end{array}$ \\
\hline $\begin{array}{l}\text { Staiger-Stock test } \\
\left.R^{2} \text { (pseudo } R^{2} \text { in cols. } 1,2,4,5 \text {; within } R^{2} \text { in cols. } 3,6,9\right)\end{array}$ & $\begin{array}{l}31.2^{* * *} \\
13.6 \%\end{array}$ & $\begin{array}{l}18.3^{* * *} \\
22.3 \%\end{array}$ & $\begin{array}{l}13.8^{* * *} \\
45.8 \%\end{array}$ & $\begin{array}{l}17.4^{* * *} \\
17.9 \%\end{array}$ & $\begin{array}{l}14.7^{* * *} \\
29.3 \%\end{array}$ & $\begin{array}{l}13.8^{* * *} \\
32.0 \%\end{array}$ & $\begin{array}{l}32.8^{* * *} \\
10.7 \%\end{array}$ & $\begin{array}{r}22.2^{* * *} \\
7.4 \%\end{array}$ & $\begin{array}{r}31.4^{* * *} \\
4.5 \%\end{array}$ \\
\hline
\end{tabular}




\section{INTERNET APPENDIX}

(NOT INTENDED FOR PUBLICATION) 


\section{Alternative Table 3. Determinants of Board Intervention. (Linear Probability Models) \\ (Standard errors clustered by country)}

This alternative version of Table 3 uses linear probability models with standard errors clustered at the country level. Results are similar if we cluster at the portfolio-firm level instead; see Table 3 in the paper. All columns except column 2 include firm fixed effects. Inclusion of firm fixed effects implies that time-invariant regressors (such as country and industry effects, the staging variable, and the privatization indicator) must be dropped from the estimation. In all other respects, the specifications are identical to those in Table 3 in the paper. The number of observations is 2,103 except in column 4, which restricts the sample to the 1,220 firmyears with lagged performance at or above plan. Heteroskedasticity-consistent standard errors, clustered at the country level, are reported in italics beneath the coefficient estimates. We use ${ }^{* * *},{ }^{* *}$, and ${ }^{*}$ to denote significance at the $1 \%, 5 \%$, and $10 \%$ level (twosided), respectively. "n.m." in columns 6 and 7 denotes "not meaningful." 
Alternative Table 3. Continued.

\begin{tabular}{|c|c|c|c|c|c|c|c|c|c|}
\hline & \multirow{2}{*}{$\begin{array}{c}=1 \text { if CEO } \\
\text { viewed as } \\
\text { incompetent } \\
\text { (1) }\end{array}$} & \multicolumn{7}{|c|}{ Dependent variable $=1$ if fire $\ldots$} & \multirow{2}{*}{$\begin{array}{c}=1 \text { if } \\
\text { streng- } \\
\text { then } \mathrm{mgt} \\
(9)\end{array}$} \\
\hline & & $\begin{array}{c}\text { CEO } \\
(2)\end{array}$ & $\begin{array}{c}\text { CEO } \\
(3)\end{array}$ & $\begin{array}{c}\text { CEO } \\
(4)\end{array}$ & $\begin{array}{l}\text { CEO } \\
(5)\end{array}$ & $\begin{array}{l}\text { CEO } \\
(6)\end{array}$ & $\begin{array}{c}\text { CEO } \\
(7)\end{array}$ & $\begin{array}{l}\text { junior } \\
\text { manager } \\
(8)\end{array}$ & \\
\hline $\begin{array}{l}\text { Board's information set and beliefs } \\
=1 \text { if manager viewed as incompetent in } t-1\end{array}$ & $0.241^{* * *}$ & $0.341^{* * *}$ & $0.398^{* * *}$ & $0.271^{* * *}$ & $0.398^{* * *}$ & $0.267^{* * *}$ & $0.234^{* * *}$ & $0.152^{* * *}$ & 0.035 \\
\hline$\ldots \mathrm{x}(=1$ if corporate governance law enacted) & 0.023 & 0.047 & 0.047 & 0.086 & 0.047 & $\begin{array}{l}0.086 \\
0.267^{* * *} \\
0.086\end{array}$ & $\begin{array}{l}0.058 \\
0.262^{* *} \\
0.108\end{array}$ & 0.040 & 0.049 \\
\hline$\ldots x$ (=1 if fund has majority ownership) & & & & & & & $\begin{array}{l}0.503^{* *} \\
0.243\end{array}$ & & \\
\hline$\ldots \times \mathrm{x}(=1$ if corporate governance law enacted $)$ & & & & & & & $\begin{array}{c}-0.408^{*} \\
0.244\end{array}$ & & \\
\hline$=1$ if poor performance blamed on bad luck in $t-1$ & $\begin{array}{r}-0.023 \\
0.018\end{array}$ & $\begin{array}{r}-0.011 \\
0.031\end{array}$ & $\begin{array}{c}-0.021 \\
0.026\end{array}$ & & $\begin{array}{c}-0.021 \\
0.026\end{array}$ & $\begin{array}{c}-0.024 \\
0.023\end{array}$ & $\begin{array}{c}-0.026 \\
0.021\end{array}$ & $\begin{array}{c}-0.030 \\
0.020\end{array}$ & $\begin{array}{l}0.014 \\
0.020\end{array}$ \\
\hline$=1$ if poor perf. blamed on manager's decisions in $t-1$ & $\begin{array}{l}0.027 \\
0.030\end{array}$ & $\begin{array}{l}0.009 \\
0.038\end{array}$ & $\begin{array}{c}-0.006 \\
0.052\end{array}$ & & $\begin{array}{c}-0.036 \\
0.060\end{array}$ & $\begin{array}{l}0.004 \\
0.053\end{array}$ & $\begin{array}{l}0.011 \\
0.042\end{array}$ & $\begin{array}{l}0.022 \\
0.074\end{array}$ & $\begin{array}{l}0.069 \\
0.060\end{array}$ \\
\hline$=1$ if board complained about moral hazard probs in $t-1$ & & & & & $\begin{array}{l}0.053 \\
0.089\end{array}$ & & & & \\
\hline performance relative to budget in $t-1$ & $\begin{array}{l}-0.015^{* *} \\
0.006\end{array}$ & $\begin{array}{l}-0.034^{* * *} \\
0.005\end{array}$ & $\begin{array}{l}-0.031^{* * *} \\
0.005\end{array}$ & $\begin{array}{l}0.005 \\
0.011\end{array}$ & $\begin{array}{l}-0.031^{* * *} \\
0.005\end{array}$ & $\begin{array}{l}-0.040^{* * *} \\
0.006\end{array}$ & $\begin{array}{l}-0.032^{* * *} \\
0.008\end{array}$ & $\begin{array}{c}-0.008 \\
0.008\end{array}$ & $\begin{array}{r}-0.007 \\
0.007\end{array}$ \\
\hline$\ldots \mathrm{x}$ (=1 if corporate governance law enacted) & & & & & & $\begin{array}{l}0.015^{*} \\
0.007\end{array}$ & & & \\
\hline $\begin{array}{l}\text { Deal characteristics } \\
\text { log investment cost through } t-1\end{array}$ & $\begin{array}{l}0.003 \\
0.003\end{array}$ & $\begin{array}{l}0.000 \\
0.004\end{array}$ & $\begin{array}{l}0.002 \\
0.002\end{array}$ & $\begin{array}{l}0.001^{*} \\
0.001\end{array}$ & $\begin{array}{l}0.002 \\
0.002\end{array}$ & $\begin{array}{l}0.002 \\
0.002\end{array}$ & $\begin{array}{l}0.002 \\
0.003\end{array}$ & $\begin{array}{l}0.000 \\
0.004\end{array}$ & $\begin{array}{l}0.002 \\
0.002\end{array}$ \\
\hline$=1$ if privatization & & $\begin{array}{l}0.045 \\
0.037\end{array}$ & & & & & & & \\
\hline$=1$ if deal is staged & & $\begin{array}{l}0.019^{* *} \\
0.008\end{array}$ & & & & & & & \\
\hline$=1$ if fund has majority ownership & & & & & & & $\begin{array}{c}-0.067 \\
0.100\end{array}$ & & \\
\hline$\ldots x$ (=1 if corp governance law enacted $)$ & & & & & & & $\begin{array}{c}-0.001 \\
0.076\end{array}$ & & \\
\hline Reform progress and macro conditions & 0.011 & 0005 & $-0116^{* * *}$ & $-0080^{* *}$ & $-0117^{* * *}$ & $-0104^{* * *}$ & $-0113^{* * *}$ & $-0161^{* * *}$ & $0100^{* *}$ \\
\hline & 0.014 & 0.019 & 0.032 & 0.035 & 0.033 & 0.033 & 0.043 & 0.055 & 0.043 \\
\hline lagged real GDP growth & $\begin{array}{l}0.000 \\
0.002\end{array}$ & $\begin{array}{l}0.000 \\
0.001\end{array}$ & $\begin{array}{r}-0.001 \\
0.002\end{array}$ & $\begin{array}{c}-0.002 \\
0.002\end{array}$ & $\begin{array}{r}-0.001 \\
0.002\end{array}$ & $\begin{array}{r}-0.002 \\
0.002\end{array}$ & $\begin{array}{r}-0.002 \\
0.002\end{array}$ & $\begin{array}{l}0.002 \\
0.002\end{array}$ & $\begin{array}{c}-0.001 \\
0.002\end{array}$ \\
\hline Instrument & & & & & & & & & \\
\hline $\begin{array}{l}=1 \text { if corporate governance law enacted empowering } \\
\text { the board to fire the CEO at will } \\
\text { Diagnostics }\end{array}$ & $\begin{array}{r}-0.007 \\
0.012\end{array}$ & $\begin{array}{l}0.078^{* * *} \\
0.012\end{array}$ & $\begin{array}{l}0.078^{* * *} \\
0.010\end{array}$ & $\begin{array}{l}0.067^{* * *} \\
0.021\end{array}$ & $\begin{array}{l}0.078^{* * *} \\
0.009\end{array}$ & $\begin{array}{l}0.017 \\
0.019\end{array}$ & $\begin{array}{l}0.064^{* * *} \\
0.024\end{array}$ & $\begin{array}{l}0.009 \\
0.012\end{array}$ & $\begin{array}{c}-0.011 \\
0.015\end{array}$ \\
\hline Staiger-Stock (1997) test $\left(\chi^{2}\right)$ & 0.3 & $44.4^{* * *}$ & $65.4^{* * *}$ & $10.1^{* * *}$ & $70.0^{* * *}$ & n.m. & n.m. & 0.6 & 0.6 \\
\hline Adjusted $R^{2}$ & $8.8 \%$ & $13.9 \%$ & $34.5 \%$ & $41.5 \%$ & $34.5 \%$ & $35.4 \%$ & $36.0 \%$ & $29.6 \%$ & $27.9 \%$ \\
\hline
\end{tabular}




\section{Alternative Table 4. Instrument Validity. (Linear Probability Models) (Standard errors clustered by country)}

This alternative version of Table 4 uses linear probability models with firm fixed effects and standard errors clustered at the country level. Results are similar if we cluster at the firm level instead; see Table 4 in the paper. Inclusion of firm fixed effects implies that timeinvariant regressors (such as country and industry effects, the staging variable, and the privatization indicator) must be dropped from the estimation. In all other respects, the specifications are identical to those in Table 4 in the paper. The number of observations is 2,103 in columns 1, 2, and 3, and 1,480 in column 4. Heteroskedasticity-consistent standard errors, clustered at the country level, are reported in italics beneath the coefficient estimates. We use ${ }^{* * *},{ }^{* *}$, and ${ }^{*}$ to denote significance at the $1 \%, 5 \%$, and $10 \%$ level (two-sided), respectively.

\begin{tabular}{|c|c|c|c|c|}
\hline & \multicolumn{4}{|c|}{ Dependent variable $=1$ if CEO is fired in year $t$} \\
\hline & $(1)$ & $(2)$ & $(3)$ & $(4)$ \\
\hline \multicolumn{5}{|l|}{ Board's information set and beliefs } \\
\hline \multirow[t]{2}{*}{$=1$ if $C E O$ viewed as incompetent in $t-1$} & $0.398^{* * *}$ & $0.397^{* * *}$ & $0.399^{* * *}$ & $0.335^{* * *}$ \\
\hline & 0.047 & 0.048 & 0.046 & 0.067 \\
\hline \multirow[t]{2}{*}{$=1$ if poor performance blamed on bad luck in $t-1$} & -0.021 & -0.019 & -0.020 & -0.002 \\
\hline & 0.026 & 0.027 & 0.027 & 0.027 \\
\hline \multirow{4}{*}{$\begin{array}{l}=1 \text { if poor performance blamed on CEO's } \\
\quad \text { decisions in } t-1 \\
\text { performance rel. to budget in } t-1\end{array}$} & -0.007 & -0.006 & -0.006 & 0.036 \\
\hline & 0.052 & 0.053 & 0.052 & 0.055 \\
\hline & $-0.031^{* * *}$ & $-0.031^{* * *}$ & $-0.031^{* * *}$ & $-0.030^{* * *}$ \\
\hline & 0.005 & 0.005 & 0.005 & 0.009 \\
\hline \multicolumn{5}{|l|}{ Deal characteristics } \\
\hline \multirow[t]{2}{*}{ log investment cost through $t-1$} & 0.002 & 0.002 & 0.002 & 0.002 \\
\hline & 0.002 & 0.003 & 0.002 & 0.003 \\
\hline \multicolumn{5}{|l|}{ Reform progress and macro conditions } \\
\hline \multirow[t]{2}{*}{ lagged EBRD transition indicator } & $-0.122^{* * *}$ & $-0.101^{* *}$ & $-0.113^{* * *}$ & $-0.096^{* *}$ \\
\hline & 0.035 & 0.045 & 0.033 & 0.038 \\
\hline \multirow[t]{2}{*}{ lagged real GDP growth } & -0.002 & -0.002 & -0.001 & -0.002 \\
\hline & 0.002 & 0.002 & 0.002 & 0.002 \\
\hline \multicolumn{5}{|l|}{ Instrument } \\
\hline \multirow{2}{*}{$\begin{array}{l}=1 \text { if corporate governance law enacted empowering } \\
\text { the board to fire the CEO at will }\end{array}$} & $0.079^{* * *}$ & & $0.082^{* * *}$ & $0.072^{* * *}$ \\
\hline & 0.010 & & 0.012 & 0.011 \\
\hline \multirow{2}{*}{$\begin{array}{l}=1 \text { if change in board's power to fire the CEO } \\
\text { requires charter amendment }\end{array}$} & 0.023 & & & \\
\hline & 0.013 & & & \\
\hline \multirow[t]{2}{*}{$=1$ if corp gov. law enacted in $t+2$} & & -0.009 & & \\
\hline & & 0.022 & & \\
\hline \multirow[t]{2}{*}{$=1$ if corp gov. law enacted in $t+1$} & & -0.014 & & \\
\hline & & 0.029 & & \\
\hline \multirow[t]{2}{*}{$=1$ if corp gov. law enacted in $t$} & & $0.085^{* * *}$ & & \\
\hline & & 0.021 & & \\
\hline \multirow[t]{2}{*}{$=1$ if corp gov. law enacted in $t-1$} & & 0.047 & & \\
\hline & & 0.052 & & \\
\hline \multirow[t]{2}{*}{$=1$ if corp gov. law enacted in $t-2$ or earlier } & & 0.066 & & \\
\hline & & 0.039 & & \\
\hline \multirow[t]{2}{*}{$=1$ if corp gov. reform mooted } & & & -0.011 & \\
\hline & & & 0.026 & \\
\hline \multicolumn{5}{|l|}{ Diagnostics } \\
\hline Wald test: all coeff. $=0(F)$ & $219.5^{* * *}$ & $80.2^{* * *}$ & $112.9^{* * *}$ & $38.9^{* * *}$ \\
\hline Staiger-Stock (1997) instrument strength test $(F)$ & $62.9^{* * *}$ & $27.0^{* * *}$ & $47.6^{* * *}$ & $41.7^{* *}$ \\
\hline Adjusted $R^{2}$ & $34.5 \%$ & $34.5 \%$ & $34.5 \%$ & $30.6 \%$ \\
\hline
\end{tabular}




\section{Alternative Table 5. Naïve and Reduced-form Exit Performance Models. (Linear Probability Models) (Standard errors clustered by country)}

This alternative version of Table 5 uses linear probability models with firm fixed effects and standard errors clustered at the country level. Results are similar if we cluster at the firm level instead; see Table 5 in the paper. Inclusion of firm fixed effects implies that timeinvariant regressors (such as country and industry effects, the staging variable, and the privatization indicator) must be dropped from the estimation. In all other respects, the specifications are identical to those in Table 5 in the paper. The number of observations is 2,103 . Heteroskedasticity-consistent standard errors, clustered at the country level, are reported in italics beneath the coefficient estimates. We use $^{* * *},{ }^{* *}$, and ${ }^{*}$ to denote significance at the $1 \%, 5 \%$, and $10 \%$ level (two-sided), respectively.

\begin{tabular}{|c|c|c|c|c|}
\hline & \multicolumn{4}{|c|}{ Dependent variable $=1$ if $\ldots$} \\
\hline & \multicolumn{2}{|c|}{$\ldots$ exit in years $t$ to $t+2$} & \multicolumn{2}{|c|}{$\begin{array}{l}\text {... exit at positive IRR in } \\
\text { years } t \text { to } t+2\end{array}$} \\
\hline & $\begin{array}{l}\text { Naïve } \\
(1)\end{array}$ & $\begin{array}{l}\text { Reduced- } \\
\text { form } \\
(2)\end{array}$ & $\begin{array}{l}\text { Naïve } \\
\text { (3) }\end{array}$ & $\begin{array}{l}\text { Reduced- } \\
\text { form } \\
(4)\end{array}$ \\
\hline \multicolumn{5}{|l|}{ Board interventions } \\
\hline$=1$ if CEO dismissed in year $t$ & $\begin{array}{l}0.017 \\
0.034\end{array}$ & & $\begin{array}{r}-0.019 \\
0.019\end{array}$ & \\
\hline \multicolumn{5}{|l|}{ Board's information set and beliefs } \\
\hline$=1$ if $\mathrm{CEO}$ viewed as incompetent in $t-1$ & $\begin{array}{r}-0.053 \\
0.041\end{array}$ & $\begin{array}{c}-0.034 \\
0.026\end{array}$ & $\begin{array}{l}0.027 \\
0.024\end{array}$ & $\begin{array}{l}0.028 \\
0.026\end{array}$ \\
\hline$=1$ if poor performance blamed on bad luck in $t-1$ & $\begin{array}{l}0.003 \\
0.028\end{array}$ & $\begin{array}{l}0.005 \\
0.038\end{array}$ & $\begin{array}{l}0.062^{* *} \\
0.022\end{array}$ & $\begin{array}{l}0.064^{* *} \\
0.023\end{array}$ \\
\hline $\begin{array}{l}=1 \text { if poor performance blamed on CEO's } \\
\text { decisions in } t-1\end{array}$ & $\begin{array}{l}0.106 \\
0.068\end{array}$ & $\begin{array}{l}0.084 \\
0.063\end{array}$ & $\begin{array}{l}0.051 \\
0.053\end{array}$ & $\begin{array}{l}0.037 \\
0.052\end{array}$ \\
\hline performance rel. to budget in $t-1$ & $\begin{array}{l}0.019 \\
0.018\end{array}$ & $\begin{array}{l}0.014 \\
0.016\end{array}$ & $\begin{array}{l}0.039^{* *} \\
0.017\end{array}$ & $\begin{array}{l}0.037^{* *} \\
0.016\end{array}$ \\
\hline Deal characteristics & & & & \\
\hline log investment cost through $t-1$ & $\begin{array}{l}0.014 \\
0.010\end{array}$ & $\begin{array}{l}0.014^{*} \\
0.008\end{array}$ & $\begin{array}{l}0.011 \\
0.007\end{array}$ & $\begin{array}{l}0.011^{* *} \\
0.005\end{array}$ \\
\hline$=1$ if privatization & & & & \\
\hline$=1$ if deal is staged & & & & \\
\hline Reform progress and macro conditions & & & & \\
\hline lagged EBRD transition indicator & $\begin{array}{l}0.016^{* * *} \\
0.005\end{array}$ & $\begin{array}{l}0.013^{* * *} \\
0.004\end{array}$ & $\begin{array}{l}0.011^{* * *} \\
0.003\end{array}$ & $\begin{array}{l}0.009^{* * *} \\
0.003\end{array}$ \\
\hline lagged real GDP growth & $\begin{array}{l}0.020^{* * *} \\
0.005\end{array}$ & $\begin{array}{l}0.024^{* * *} \\
0.003\end{array}$ & $\begin{array}{l}0.016^{* * *} \\
0.002\end{array}$ & $\begin{array}{l}0.019^{* * *} \\
0.003\end{array}$ \\
\hline Instrument & & & & \\
\hline $\begin{array}{l}=1 \text { if corporate governance law enacted } \\
\text { empowering the board to fire the CEO at will }\end{array}$ & & $\begin{array}{l}0.346^{* * *} \\
0.064\end{array}$ & & $\begin{array}{l}0.221^{* * *} \\
0.033\end{array}$ \\
\hline Diagnostics & & & & \\
\hline Portfolio-firm effects? & Yes & Yes & Yes & Yes \\
\hline Wald test: all coeff. $=0\left(\chi^{2}\right)$ & $44.9^{* * *}$ & $20461^{* * *}$ & $22.9^{* * *}$ & $934.2^{* * *}$ \\
\hline Adjusted $R^{2}$ & $58.2 \%$ & $60.7 \%$ & $62.8 \%$ & $64.0 \%$ \\
\hline
\end{tabular}




\section{Alternative Table 6. Structural Performance Models Using Law Changes as an Instrument. (Standard errors clustered by country)}

This alternative version of Table 6 reports standard errors clustered by country rather than by portfolio firm (except in columns 2 and 5 , where the inclusion of random firm effects rules out clustering). We use ${ }^{* * *},{ }^{* *}$, and ${ }^{*}$ to denote significance at the $1 \%, 5 \%$, and $10 \%$ level (two-sided), respectively. The number of observations is 2,103 .

\begin{tabular}{|c|c|c|c|c|c|c|}
\hline & \multicolumn{6}{|c|}{ Dependent variable $=1$ if $\ldots$} \\
\hline & \multicolumn{3}{|c|}{$\ldots$ exit in years $t$ to $t+2$} & \multicolumn{3}{|c|}{$\ldots$ exit at positive IRR in $t$ to $t+2$} \\
\hline & \multicolumn{2}{|c|}{ Bivariate probit } & \multirow{2}{*}{$\begin{array}{c}\text { 2SLS } \\
\text { (3) }\end{array}$} & \multicolumn{2}{|c|}{ Bivariate probit } & \multirow{2}{*}{$\begin{array}{c}\text { 2SLS } \\
(6)\end{array}$} \\
\hline & (1) & $(2)$ & & (4) & $(5)$ & \\
\hline \multicolumn{7}{|l|}{ Board interventions } \\
\hline \multirow[t]{2}{*}{$=1$ if CEO dismissed in year $t$} & $1.232^{* * *}$ & $1.805^{* * *}$ & $1.329^{* * *}$ & $1.256^{* * *}$ & $1.396^{* * *}$ & $0.747^{* *}$ \\
\hline & 0.339 & 0.171 & 0.432 & 0.173 & 0.329 & 0.341 \\
\hline \multicolumn{7}{|l|}{ Board's information set and beliefs } \\
\hline \multirow[t]{2}{*}{$=1$ if $\mathrm{CEO}$ viewed as incompetent in $t-1$} & $-0.492^{*}$ & $-0.868^{* * *}$ & $-0.587^{* * *}$ & $-0.429^{* *}$ & -0.488 & $-0.286^{* *}$ \\
\hline & 0.273 & 0.169 & 0.191 & 0.204 & 0.296 & 0.144 \\
\hline \multirow[t]{2}{*}{$=1$ if poor perf. blamed on bad luck in $t-1$} & -0.001 & 0.003 & -0.036 & 0.146 & 0.038 & 0.034 \\
\hline & 0.069 & 0.119 & 0.033 & 0.116 & 0.163 & 0.035 \\
\hline \multirow{4}{*}{$\begin{array}{l}=1 \text { if poor performance blamed on CEO's } \\
\quad \text { decisions in } t-1 \\
\text { performance in year } t-1 \text { relative to budget }\end{array}$} & 0.216 & 0.061 & 0.010 & 0.047 & 0.065 & -0.013 \\
\hline & 0.171 & 0.222 & 0.054 & 0.211 & 0.313 & 0.037 \\
\hline & $0.178^{* * *}$ & $0.153^{* *}$ & $0.056^{* * *}$ & $0.368^{* * *}$ & $0.292^{* * *}$ & $0.060^{* * *}$ \\
\hline & 0.045 & 0.042 & 0.020 & 0.034 & 0.056 & 0.015 \\
\hline \multicolumn{7}{|l|}{ Deal characteristics } \\
\hline \multirow[t]{2}{*}{ log investment cost through $t-1$} & $0.061^{* *}$ & $0.323^{* * *}$ & $-0.012^{* * *}$ & $0.101^{*}$ & $0.651^{* * *}$ & $-0.007^{* * *}$ \\
\hline & 0.027 & 0.036 & 0.005 & 0.060 & 0.053 & 0.002 \\
\hline \multirow[t]{2}{*}{$=1$ if privatization } & -0.022 & 0.007 & & 0.105 & $0.153^{* * *}$ & \\
\hline & 0.133 & 0.016 & & 0.143 & 0.021 & \\
\hline \multirow[t]{2}{*}{$=1$ if deal is staged } & $-0.378^{* * *}$ & $-0.139^{* * *}$ & & $-0.278^{* * *}$ & $-0.136^{* * *}$ & \\
\hline & 0.088 & 0.010 & & 0.106 & 0.013 & \\
\hline \multicolumn{7}{|l|}{ Reform progress and macro conditions } \\
\hline \multirow{2}{*}{ lagged EBRD transition indicator } & 0.648 & $0.639^{* * *}$ & $0.286^{* * *}$ & 0.316 & $0.807^{* * *}$ & $0.200^{* * *}$ \\
\hline & 0.396 & 0.028 & 0.064 & 0.346 & 0.040 & 0.069 \\
\hline \multirow[t]{2}{*}{ lagged real GDP growth } & $0.061^{* * *}$ & $0.167^{* * *}$ & $0.010^{* * *}$ & $0.063^{* * *}$ & $0.217^{* * *}$ & $0.010^{* *}$ \\
\hline & 0.015 & 0.014 & 0.004 & 0.012 & 0.018 & 0.004 \\
\hline \multicolumn{7}{|l|}{ Diagnostics } \\
\hline Portfolio-firm effects? & No & Random & Fixed & No & Random & Fixed \\
\hline Wald test: all coeff. $=0\left(\chi^{2}\right)$ & $865.1^{* * *}$ & $1102.7^{* * *}$ & $1667.1^{* * *}$ & $917.1^{* * *}$ & $819.5^{* * *}$ & $867.0^{* * *}$ \\
\hline Exogeneity test (LR test) $\left(\chi^{2}\right)$ & $11.0^{* * *}$ & $351.9^{* * *}$ & n.m. & $9.5^{* * *}$ & $441.1^{* * *}$ & n.m. \\
\hline Staiger-Stock test $\left(\chi^{2}\right)$ & $47.4^{* * *}$ & $16.2^{* * *}$ & $73.3^{* * *}$ & $28.3^{* * *}$ & $12.5^{* * *}$ & $73.3^{* * *}$ \\
\hline Pseudo- $R^{2}$; within-groups $R^{2}$ in cols. 3,6 & $13.5 \%$ & $22.0 \%$ & $45.9 \%$ & $17.7 \%$ & $29.3 \%$ & $32.0 \%$ \\
\hline
\end{tabular}




\section{Alternative Table 7. Effect of Board Intervention on Performance Relative to Budget.}

\section{(Standard errors clustered by country)}

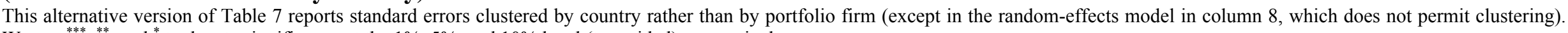
We use ${ }^{* * *},{ }^{* *}$, and ${ }^{*}$ to denote significance at the $1 \%, 5 \%$, and $10 \%$ level (two-sided), respectively.

\begin{tabular}{|c|c|c|c|c|c|c|c|c|c|}
\hline & \multicolumn{9}{|c|}{ Dependent variable: Performance in year $t+1$ relative to budget } \\
\hline & \multicolumn{3}{|c|}{ Naïve models } & \multicolumn{3}{|c|}{ Reduced-form models } & \multicolumn{3}{|c|}{ IV models } \\
\hline & (1) & (2) & (3) & (4) & (5) & (6) & (7) & (8) & (9) \\
\hline \multicolumn{10}{|l|}{ Board interventions } \\
\hline \multirow{2}{*}{$=1$ if CEO dismissed in year $t$} & $0.183^{*}$ & $0.225^{* *}$ & $0.342^{* * *}$ & & & & $1.579^{* * *}$ & $1.944^{* *}$ & $2.168^{* * *}$ \\
\hline & 0.104 & 0.096 & 0.111 & & & & 0.193 & 0.935 & 0.664 \\
\hline \multicolumn{10}{|l|}{ Board's information set and beliefs } \\
\hline \multirow[t]{2}{*}{$=1$ if CEO viewed as incompetent in $t-1$} & $-0.226^{* * *}$ & $-0.150^{* *}$ & -0.052 & $-0.154^{* * *}$ & -0.057 & $0.102^{*}$ & $-0.743^{* * *}$ & $-0.865^{* *}$ & $-0.850^{* * *}$ \\
\hline & 0.075 & 0.060 & 0.071 & 0.052 & 0.039 & 0.049 & 0.127 & 0.375 & 0.281 \\
\hline \multirow{2}{*}{$=1$ if poor perf. blamed on bad luck in $t-1$} & $0.290^{* * *}$ & $0.261^{* * *}$ & $0.206^{* * *}$ & $0.277^{* * *}$ & $0.246^{* * *}$ & $0.180^{* * *}$ & $0.333^{* * *}$ & $0.337^{* * *}$ & $0.301^{* * *}$ \\
\hline & 0.083 & 0.068 & 0.062 & 0.082 & 0.068 & 0.058 & 0.096 & 0.095 & 0.076 \\
\hline \multirow{4}{*}{$\begin{array}{l}=1 \text { if poor performance blamed on CEO's } \\
\text { decisions in } t-1 \\
\text { performance in year } t-1 \text { relative to budget }\end{array}$} & 0.170 & 0.253 & 0.322 & 0.163 & 0.239 & 0.308 & 0.119 & 0.136 & 0.246 \\
\hline & 0.312 & 0.316 & 0.304 & 0.308 & 0.313 & 0.301 & 0.316 & 0.161 & 0.367 \\
\hline & $0.310^{* * *}$ & $0.144^{* * *}$ & $-0.098^{* * *}$ & $0.298^{* * *}$ & $0.132^{* * *}$ & $-0.115^{* * *}$ & $0.382^{* * *}$ & $0.346^{* * *}$ & -0.023 \\
\hline & 0.044 & 0.037 & 0.026 & 0.041 & 0.033 & 0.023 & 0.042 & 0.058 & 0.038 \\
\hline \multicolumn{10}{|l|}{ Deal characteristics } \\
\hline \multirow[t]{2}{*}{$\log$ investment cost through $t-1$} & $0.033^{* *}$ & $0.023^{* *}$ & 0.004 & $0.032^{* *}$ & $0.022^{*}$ & 0.005 & $0.032^{* *}$ & $0.029^{*}$ & -0.002 \\
\hline & 0.014 & 0.011 & 0.012 & 0.015 & 0.012 & 0.012 & 0.015 & 0.017 & 0.015 \\
\hline \multirow[t]{2}{*}{$=1$ if privatization } & $0.212^{*}$ & $0.256^{* *}$ & & $0.224^{* *}$ & $0.274^{* *}$ & & 0.154 & 0.153 & \\
\hline & 0.107 & 0.110 & & 0.106 & 0.111 & & 0.142 & 0.138 & \\
\hline \multirow[t]{2}{*}{$=1$ if deal is staged } & -0.070 & -0.070 & & -0.067 & -0.068 & & -0.095 & -0.100 & \\
\hline & 0.062 & 0.077 & & 0.060 & 0.074 & & 0.066 & 0.072 & \\
\hline \multicolumn{10}{|l|}{ Reform progress and macro conditions } \\
\hline \multirow[t]{2}{*}{ lagged EBRD transition indicator } & -0.165 & -0.188 & -0.458 & $-0.249^{*}$ & -0.296 & $-0.679^{* *}$ & $-0.230^{* *}$ & $-0.246^{*}$ & $-0.450^{* *}$ \\
\hline & 0.128 & 0.179 & 0.328 & 0.127 & 0.183 & 0.301 & 0.103 & 0.137 & 0.219 \\
\hline \multirow[t]{2}{*}{ lagged real GDP growth } & 0.007 & 0.006 & 0.002 & 0.008 & 0.007 & 0.004 & 0.011 & 0.012 & 0.010 \\
\hline & 0.008 & 0.009 & 0.012 & 0.007 & 0.008 & 0.012 & 0.007 & 0.009 & 0.013 \\
\hline \multicolumn{10}{|l|}{ Instrument } \\
\hline \multirow{2}{*}{\multicolumn{4}{|c|}{$\begin{array}{l}=1 \text { if corporate governance law enacted } \\
\text { empowering the board to fire the CEO at will }\end{array}$}} & $0.181^{* *}$ & $0.203^{* * *}$ & $0.255^{* * *}$ & & & \\
\hline & & & & 0.068 & 0.064 & 0.061 & & & \\
\hline \multicolumn{10}{|l|}{ Diagnostics } \\
\hline Portfolio-firm effects? & No & Random & Fixed & No & Random & Fixed & No & Random & Fixed \\
\hline Wald test: independent equations & n.a. & n.a. & n.a. & n.a. & n.a. & n.a. & $28.2^{* * *}$ & n.a. & n.a. \\
\hline Staiger-Stock test $\left(\chi^{2} ; F\right.$ in cols $\left.3,6,9\right)$ & n.a. & n.a. & n.a. & n.a. & n.a. & n.a. & $21.8^{* * *}$ & $19.1^{* * *}$ & $34.4^{* * *}$ \\
\hline$R^{2}$ & $16.9 \%$ & $14.3 \%$ & $5.1 \%$ & $16.9 \%$ & $14.4 \%$ & $5.1 \%$ & $10.7 \%$ & $8.5 \%$ & $4.5 \%$ \\
\hline
\end{tabular}




\section{Alternative Table 8. Addressing Identification Concerns. \\ (Linear Probability Models) \\ (Standard errors clustered by country)}

This alternative version of Table 8 reports linear probability models rather than probits and standard errors clustered by country rather than by portfolio firm. We use ${ }^{* * *},{ }^{* *}$, and ${ }^{*}$ to denote significance at the $1 \%, 5 \%$, and $10 \%$ level (two-sided), respectively.

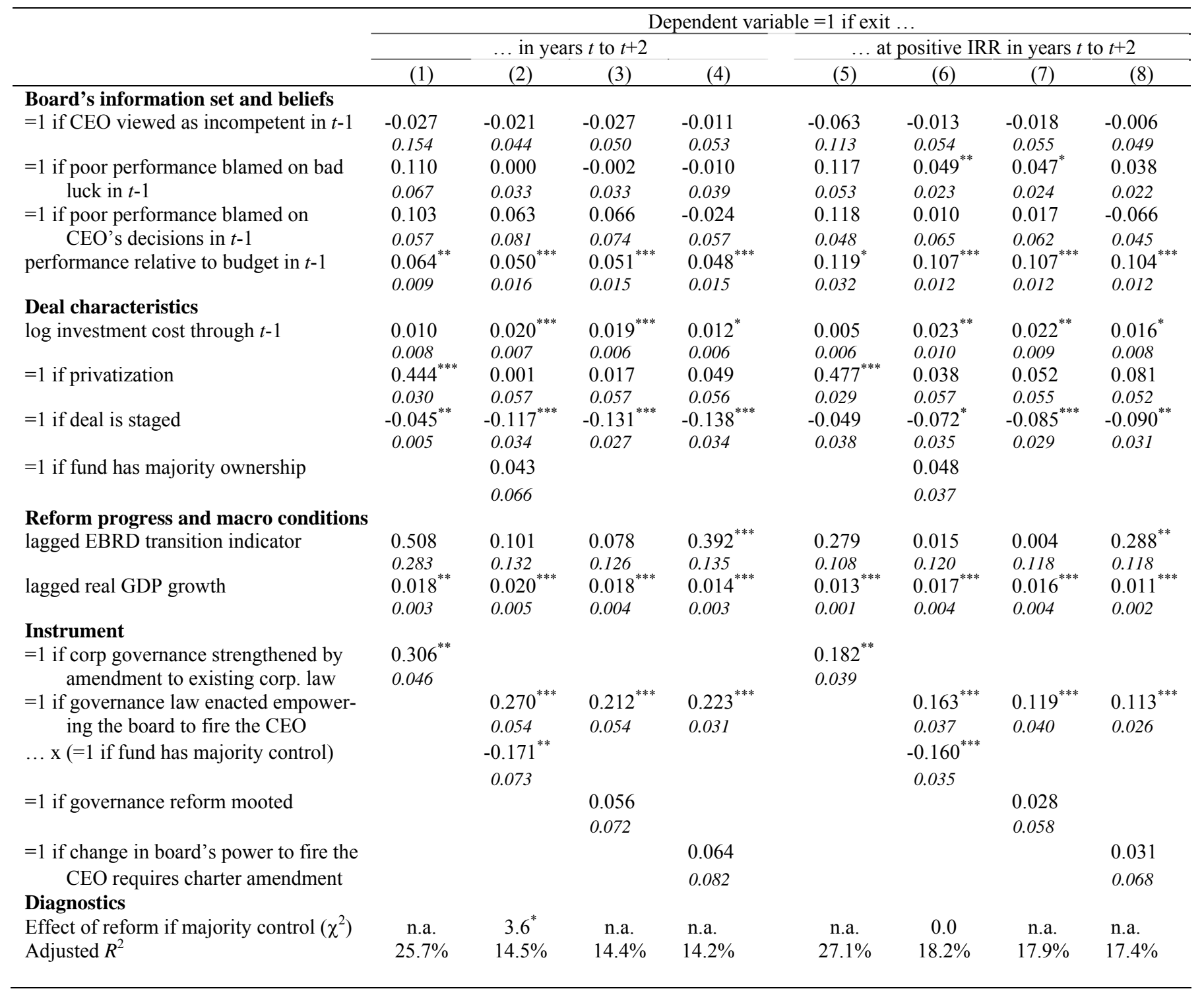




\section{Alternative Table 9. Testing for Selection Effects.}

\section{(Standard errors clustered by country)}

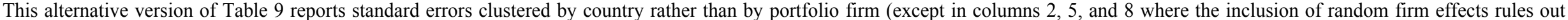
clustering). We use ${ }^{* * *},{ }^{* *}$, and ${ }^{*}$ to denote significance at the $1 \%, 5 \%$, and $10 \%$ level (two-sided), respectively.

\begin{tabular}{|c|c|c|c|c|c|c|c|c|c|}
\hline & \multicolumn{6}{|c|}{ Dependent variable $=1$ if $\ldots$} & \multirow{3}{*}{\multicolumn{3}{|c|}{$\begin{array}{c}\text { Dep. variable: Performance in year } \\
t+1 \text { rel. to budget } \\
\text { Instrumental variables model }\end{array}$}} \\
\hline & \multicolumn{3}{|c|}{... exit in years $t$ to $t+2$} & \multicolumn{3}{|c|}{... exit at positive IRR in $t$ to $t+2$} & & & \\
\hline & \multicolumn{2}{|c|}{ Bivariate probit } & \multirow{2}{*}{$\begin{array}{l}\text { 2SLS } \\
\mathrm{w} / \mathrm{FE} \\
(3)\end{array}$} & \multicolumn{2}{|c|}{ Bivariate probit } & \multirow{2}{*}{$\begin{array}{l}\text { 2SLS } \\
\text { w/ FE } \\
(6)\end{array}$} & & & \\
\hline & $\begin{array}{l}\text { w/o RE } \\
(1)\end{array}$ & $\begin{array}{l}\mathrm{w} / \mathrm{RE} \\
(2)\end{array}$ & & $\begin{array}{l}\text { w/o RE } \\
(4)\end{array}$ & $\begin{array}{l}\mathrm{W} / \mathrm{RE} \\
(5)\end{array}$ & & $\begin{array}{l}\text { w/o FE } \\
(7)\end{array}$ & $\begin{array}{c}\mathrm{w} / \mathrm{RE} \\
(8)\end{array}$ & $\begin{array}{c}\mathrm{w} / \mathrm{FE} \\
(9)\end{array}$ \\
\hline \multicolumn{10}{|c|}{ Panel A: Baseline models (reproduced from Alternative Tables 6 and 7) } \\
\hline$=1$ if CEO dismissed in year $t$ & $\begin{array}{l}1.232^{* * *} \\
0.339\end{array}$ & $\begin{array}{l}1.805^{* * *} \\
0.171\end{array}$ & $\begin{array}{l}1.329^{* * *} \\
0.432\end{array}$ & $\begin{array}{l}1.256^{* * *} \\
0.173\end{array}$ & $\begin{array}{l}1.396^{* * *} \\
0.329\end{array}$ & $\begin{array}{l}0.747^{* *} \\
0.341\end{array}$ & $\begin{array}{l}1.579^{* * *} \\
0.193\end{array}$ & $\begin{array}{l}1.944^{* *} \\
0.935\end{array}$ & $\begin{array}{l}2.168^{* * *} \\
0.664\end{array}$ \\
\hline $\begin{array}{l}\text { Staiger-Stock test } \\
\left.R^{2} \text { (pseudo } R^{2} \text { in cols. } 1,2,4,5 \text {; within } R^{2} \text { in cols. } 3,6,9\right)\end{array}$ & $\begin{array}{l}47.4^{* * *} \\
13.5 \%\end{array}$ & $\begin{array}{l}16.2^{* * *} \\
22.0 \%\end{array}$ & $\begin{array}{l}73.3^{* * *} \\
45.9 \%\end{array}$ & $\begin{array}{l}28.3^{* * *} \\
17.7 \%\end{array}$ & $\begin{array}{l}12.5^{* * *} \\
29.3 \%\end{array}$ & $\begin{array}{l}73.3^{* * *} \\
32.0 \%\end{array}$ & $\begin{array}{l}21.8^{* * *} \\
10.7 \%\end{array}$ & $\begin{array}{c}19.1^{* * *} \\
8.5 \%\end{array}$ & $\begin{array}{c}34.4^{* * *} \\
4.5 \%\end{array}$ \\
\hline \multicolumn{10}{|c|}{ Panel B: Investments made 2 or more years before law change } \\
\hline$=1$ if CEO dismissed in year $t$ & $\begin{array}{l}1.130^{* * *} \\
0.291\end{array}$ & $\begin{array}{l}1.785^{* * *} \\
0.206\end{array}$ & $\begin{array}{l}1.233^{*} \\
0.646\end{array}$ & $\begin{array}{l}1.267^{* * *} \\
0.460\end{array}$ & $\begin{array}{l}1.497^{* * *} \\
0.445\end{array}$ & $\begin{array}{l}0.700^{* *} \\
0.331\end{array}$ & $\begin{array}{l}1.509^{* * *} \\
0.283\end{array}$ & $\begin{array}{l}2.284^{* *} \\
1.026\end{array}$ & $\begin{array}{l}2.076^{* * *} \\
0.563\end{array}$ \\
\hline $\begin{array}{l}\text { Staiger-Stock test } \\
\left.R^{2} \text { (pseudo } R^{2} \text { in cols. } 1,2,4,5 \text {; within } R^{2} \text { in cols. } 3,6,9\right)\end{array}$ & $\begin{array}{l}40.1^{* * *} \\
16.8 \%\end{array}$ & $\begin{array}{l}18.2^{* * *} \\
24.4 \%\end{array}$ & $\begin{array}{l}68.4^{* * *} \\
47.4 \%\end{array}$ & $\begin{array}{l}23.2^{* * *} \\
20.2 \%\end{array}$ & $\begin{array}{l}11.9^{* * *} \\
30.2 \%\end{array}$ & $\begin{array}{l}68.4^{* * *} \\
32.5 \%\end{array}$ & $\begin{array}{l}13.9^{* * *} \\
12.6 \%\end{array}$ & $\begin{array}{c}15.4^{* * *} \\
6.3 \%\end{array}$ & $\begin{array}{c}33.1^{* * *} \\
4.5 \%\end{array}$ \\
\hline \multicolumn{10}{|l|}{ Panel C: Investments made before law change first rumored } \\
\hline$=1$ if CEO dismissed in year $t$ & $\begin{array}{l}0.996^{* * *} \\
0.263\end{array}$ & $\begin{array}{l}1.735^{* * *} \\
0.230\end{array}$ & $\begin{array}{l}1.269^{* *} \\
0.622\end{array}$ & $\begin{array}{l}1.115^{* *} \\
0.449\end{array}$ & $\begin{array}{l}2.013^{* * *} \\
0.207\end{array}$ & $\begin{array}{l}0.704^{* *} \\
0.322\end{array}$ & $\begin{array}{l}1.187^{* * *} \\
0.327\end{array}$ & $\begin{array}{l}2.317^{* *} \\
0.957\end{array}$ & $\begin{array}{l}2.252^{* * *} \\
0.663\end{array}$ \\
\hline $\begin{array}{l}\text { Staiger-Stock test } \\
R^{2} \text { (pseudo } R^{2} \text { in cols. } 1,2,4,5 \text {; within } R^{2} \text { in cols. } 3,6,9 \text { ) }\end{array}$ & $\begin{array}{l}126.2^{* * *} \\
17.2 \%\end{array}$ & $\begin{array}{l}17.0^{* * *} \\
24.9 \%\end{array}$ & $\begin{array}{l}54.7^{* * *} \\
47.3 \%\end{array}$ & $\begin{array}{l}51.8^{* * *} \\
20.4 \%\end{array}$ & $\begin{array}{l}14.0^{* * *} \\
30.7 \%\end{array}$ & $\begin{array}{l}54.7^{* * *} \\
31.9 \%\end{array}$ & $\begin{array}{l}34.5^{* * *} \\
13.4 \%\end{array}$ & $\begin{array}{r}18.2^{* * *} \\
5.3 \%\end{array}$ & $\begin{array}{r}23.9^{* * *} \\
5.5 \%\end{array}$ \\
\hline
\end{tabular}




\section{Alternative Table 10. Robustness Tests.}

\section{(Standard errors clustered by country)}

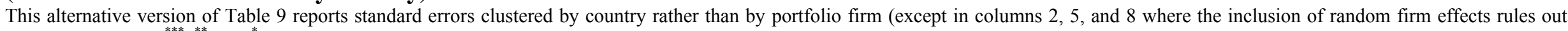
clustering). We use ${ }^{* * *},{ }^{* *}$, and ${ }^{*}$ to denote significance at the $1 \%, 5 \%$, and $10 \%$ level (two-sided), respectively.

\begin{tabular}{|c|c|c|c|c|c|c|c|c|c|}
\hline & \multicolumn{6}{|c|}{ Dependent variable $=1$ if $\ldots$} & \multirow{3}{*}{\multicolumn{3}{|c|}{$\begin{array}{l}\text { Dep. variable: Performance in year } \\
t+1 \text { rel. to budget } \\
\text { Instrumental variables model }\end{array}$}} \\
\hline & \multicolumn{3}{|c|}{$\ldots$ exit in years $t$ to $t+2$} & \multicolumn{3}{|c|}{$\ldots$ exit at positive IRR in $t$ to $t+2$} & & & \\
\hline & \multicolumn{2}{|c|}{ Bivariate probit } & \multirow{2}{*}{$\begin{array}{c}\text { 2SLS } \\
\mathrm{w} / \mathrm{FE} \\
(3)\end{array}$} & \multicolumn{2}{|c|}{ Bivariate probit } & \multirow{2}{*}{$\begin{array}{c}\text { 2SLS } \\
\mathrm{w} / \mathrm{FE} \\
(6) \\
\end{array}$} & & & \\
\hline & $\begin{array}{c}\text { w/o RE } \\
(1)\end{array}$ & $\begin{array}{c}\mathrm{w} / \mathrm{RE} \\
(2)\end{array}$ & & $\begin{array}{c}\text { w/o RE } \\
(4)\end{array}$ & $\begin{array}{c}\mathrm{w} / \mathrm{RE} \\
(5)\end{array}$ & & $\begin{array}{l}\text { w/o FE } \\
(7)\end{array}$ & $\begin{array}{c}\mathrm{w} / \mathrm{RE} \\
(8)\end{array}$ & $\begin{array}{c}\text { w/ FE } \\
(9)\end{array}$ \\
\hline \multicolumn{10}{|l|}{ Panel A: Alternative exit horizon (exit in year $t$ or $t$} \\
\hline$=1$ if CEO dismissed in year $t$ & $\begin{array}{l}0.798 \\
0.524\end{array}$ & $\begin{array}{l}1.192^{* * *} \\
0.280\end{array}$ & $\begin{array}{l}0.658^{* *} \\
0.335\end{array}$ & $\begin{array}{l}1.494^{* * *} \\
0.306\end{array}$ & $\begin{array}{l}1.690^{* * *} \\
0.155\end{array}$ & $\begin{array}{l}0.226 \\
0.454\end{array}$ & n.a. & n.a. & n.a. \\
\hline $\begin{array}{l}\text { Staiger-Stock test } \\
\left.R^{2} \text { (pseudo } R^{2} \text { in cols. } 1,2,4,5 \text {; within } R^{2} \text { in cols. } 3,6,9\right)\end{array}$ & $\begin{array}{l}33.7^{* * *} \\
12.4 \%\end{array}$ & $\begin{array}{l}14.8^{* * *} \\
13.5 \%\end{array}$ & $\begin{array}{l}73.3^{* * *} \\
37.4 \%\end{array}$ & $\begin{array}{l}27.8^{* * *} \\
16.2 \%\end{array}$ & $\begin{array}{l}12.9^{* * *} \\
19.4 \%\end{array}$ & $\begin{array}{l}73.3^{* * *} \\
26.5 \%\end{array}$ & & & \\
\hline \multicolumn{10}{|l|}{ Panel B: Time-varying law changes } \\
\hline$=1$ if CEO dismissed in year $t$ & $\begin{array}{l}1.392^{* * *} \\
0.394\end{array}$ & $\begin{array}{l}1.822^{* * *} \\
0.160\end{array}$ & $\begin{array}{l}1.434^{* * *} \\
0.426\end{array}$ & $\begin{array}{l}1.305^{* * *} \\
0.180\end{array}$ & $\begin{array}{l}1.345^{* * *} \\
0.366\end{array}$ & $\begin{array}{l}0.925^{* * *} \\
0.342\end{array}$ & $\begin{array}{l}1.586^{* * *} \\
0.202\end{array}$ & $\begin{array}{l}1.784^{* *} \\
0.915\end{array}$ & $\begin{array}{l}2.059^{* * *} \\
0.451\end{array}$ \\
\hline $\begin{array}{l}\text { Staiger-Stock test } \\
\left.R^{2} \text { (pseudo } R^{2} \text { in cols. } 1,2,4,5 \text {; within } R^{2} \text { in cols. } 3,6,9\right)\end{array}$ & $\begin{array}{l}39.4^{* * *} \\
13.5 \%\end{array}$ & $\begin{array}{l}23.7^{* * * *} \\
22.2 \%\end{array}$ & $\begin{array}{l}27.1^{* * *} \\
46.1 \%\end{array}$ & $\begin{array}{l}20.9^{* * *} \\
17.7 \%\end{array}$ & $\begin{array}{l}13.8^{* * *} \\
28.2 \%\end{array}$ & $\begin{array}{l}27.1^{* * *} \\
32.2 \%\end{array}$ & $\begin{array}{l}58.5^{* * *} \\
10.7 \%\end{array}$ & $\begin{array}{c}19.1^{* * *} \\
9.1 \%\end{array}$ & $\begin{array}{c}41.6^{* * *} \\
4.7 \%\end{array}$ \\
\hline \multicolumn{10}{|l|}{ Panel C: Heterogeneous country effects } \\
\hline$=1$ if CEO dismissed in year $t$ & $\begin{array}{l}1.223^{* * *} \\
0.349\end{array}$ & $\begin{array}{l}1.732^{* * *} \\
0.189\end{array}$ & $\begin{array}{l}1.224^{* * *} \\
0.401\end{array}$ & $\begin{array}{l}1.258^{* * *} \\
0.189\end{array}$ & $\begin{array}{l}1.372^{* * *} \\
0.328\end{array}$ & $\begin{array}{l}0.674^{* *} \\
0.315\end{array}$ & $\begin{array}{l}1.571^{* * *} \\
0.221\end{array}$ & $\begin{array}{l}1.971^{* *} \\
0.858\end{array}$ & $\begin{array}{l}1.888^{* * *} \\
0.389\end{array}$ \\
\hline $\begin{array}{l}\text { Staiger-Stock test } \\
\left.R^{2} \text { (pseudo } R^{2} \text { in cols. } 1,2,4,5 \text {; within } R^{2} \text { in cols. } 3,6,9\right)\end{array}$ & $\begin{array}{l}63.5^{* * *} \\
13.6 \%\end{array}$ & $\begin{array}{l}18.3^{* * *} \\
22.3 \%\end{array}$ & $\begin{array}{l}142.5^{* * *} \\
45.8 \%\end{array}$ & $\begin{array}{l}41.5^{* * *} \\
17.9 \%\end{array}$ & $\begin{array}{l}14.7^{* * *} \\
29.3 \%\end{array}$ & $\begin{array}{l}142.5^{* * *} \\
32.0 \%\end{array}$ & $\begin{array}{l}51.6^{* * *} \\
10.7 \%\end{array}$ & $\begin{array}{c}22.2^{* * *} \\
7.4 \%\end{array}$ & $\begin{array}{c}58.7^{* * *} \\
4.5 \%\end{array}$ \\
\hline
\end{tabular}

